\title{
DIREITO ECONÔMICO DA TRIBUTAÇÃO UMA ANÁLISE DA EXTRAFISCALIDADE NO SISTEMA TRIBUTÁRIO BRASILEIRO
}

Dissertação de Mestrado

Orientador: Professor Titular Gilberto Bercovici

Faculdade de Direito da Universidade de São Paulo

São Paulo

2013 



\section{DIREITO ECONÔMICO DA TRIBUTAÇÃO}

UMA ANÁLISE DA EXTRAFISCALIDADE NO SISTEMA TRIBUTÁRIO BRASILEIRO 


\section{DIREITO ECONÔMICO DA TRIBUTAÇÃO}

\section{UMA ANÁLISE DA EXTRAFISCALIDADE NO SISTEMA TRIBUTÁRIO BRASILEIRO}

Dissertação apresentada ao Departamento de Direito Econômico, Financeiro e Tributário da Faculdade de Direito da Universidade de São Paulo como requisito parcial à obtenção do título de Mestre.

Orientador: Professor Titular Gilberto Bercovici

Faculdade de Direito da Universidade de São Paulo

São Paulo 


\section{DIREITO ECONÔMICO DA TRIBUTAÇÃO UMA ANÁLISE DA EXTRAFISCALIDADE NO SISTEMA TRIBUTÁRIO BRASILEIRO}

Dissertação apresentada ao Departamento de Direito Econômico, Financeiro e Tributário da Faculdade de Direito da Universidade de São Paulo como requisito parcial à obtenção do título de Mestre.

Orientador: Professor Titular Gilberto Bercovici

Aprovado em:

BANCA EXAMINADORA

Prof.

Instituição:

Julgamento: Assinatura:

Prof.

Instituição:

Julgamento: Assinatura:

Prof.

Instituição:

Julgamento: Assinatura: 
À Maria Helena, Ernestina, Antônio Wilson, Renato e Alba. 


\section{AGRADECIMENTOS}

O nome do autor, estampado em letras prateadas no topo da capa dura revestida de percalux, pode conduzir os leitores à falsa percepção de que as páginas que se seguem são fruto de um trabalho individual. Completamente individuais são somente os equívocos e as insuficiências deste trabalho.

Diz a canção dos Strokes que apenas dez decisões moldam toda a nossa vida, mas mesmo assim nós só nos damos conta de, no máximo, cinco delas. ${ }^{1}$ Portanto, se na maioria das vezes não pude reconhecer, à época, que aqueles momentos, conversas e pessoas estavam sendo decisivos pra moldar a minha trajetória e a deste trabalho, nada mais justo do que reconhecer sua importância agora.

Antes de tudo, eu provavelmente não teria tido interesse de me enveredar pela pósgraduação ou pelo direito econômico se não tivesse passado pelo movimento estudantil da São Francisco. Especialmente se não tivesse feito parte do Fórum da Esquerda, grupo político que integrei durante os anos de faculdade, onde cultivei o gosto pelo debate, pela polêmica, pela divergência, pela política, pelo Brasil e pela transformação do mundo. Paixões essas que conjugadas são um poderoso combustível para as ideias. Aos companheiros que viveram comigo esses momentos, meu agradecimento: Veridiana Alimonti, Renan Quinalha, Renan Kalil, Zeca Calegari, Gabriel Muniz, Walter Andrade, Marina Menezes, Laura Benda, Paulo Leonardo Martins, Rafaela Barbosa, Maria Clara Troncoso, Nayara Meira, Marina Ganzarolli, Flávia Anemberg, André Tozato, Silas Cardoso, Francisco Brito Cruz, Maia Aguilera, Ivan de Franco e todos os demais que a falta de espaço não me permitiu nominar.

Outro fator decisivo para este trabalho foi a orientação do Professor Gilberto Bercovici, o Giba. Sempre disponível, solícito e direto, me apontava sem hesitação meus equívocos e as raízes dos problemas sobre os quais eu queria me debruçar. Embora eu geralmente saísse atordoado de nossas conversas, matutando minhas dúvidas enquanto digeria suas certezas, invariavelmente seus apontamentos me

\footnotetext{
1 "Ten decisions shape your life/ You'll be aware of five about/ Seven ways to go trough school/ Either you're noticed or left out/ Seven ways to get ahead/ Seven reasons to drop out” In: The Strokes, I'll Try Anything Once. Heart in a Cage. CD2. Uk, 2006.
} 
levavam a superar as armadilhas e as falsas polêmicas. Debates como sobre o direito econômico e o federalismo fiscal não seriam os mesmos sem a sua orientação.

Entretanto, também tive a sorte de contar com muitos outros orientadores, amigos com quem pude dividir angústias intelectuais, desde o momento de elaboração do projeto até a entrega final. Muitos, provavelmente, nem sabem o quanto algumas boas conversas que tivemos, às vezes sobre assuntos diversos, foram fundamentais para essa dissertação. A esses amigos, orientadores de todas as horas, fica meu muito obrigado: Mario Schapiro, Fernando Rugitsky, Lúcia Del Pichia, Marco Aurélio Braga, Alvaro Pereira, Alessandro Octavianni, Diogo de Sant'Ana, Vinícius Marques de Carvalho, Ademir Picanço e tantos outros.

Também foi graças à oportunidade que tive de assessorar a bancada do Partido dos Trabalhadores na Comissão de Assuntos Econômicos do Senado Federal, entre 2010 e 2012, que esta dissertação tomou a forma atual, sobretudo no terceiro capítulo. Lá, pude acompanhar de perto as tentativas de reforma do sistema tributário nacional, principalmente a batalha que foi a aprovação da Resolução do Senado Federal $\mathrm{n}^{\mathrm{o}}$ 13/2012. Nesse processo fui estimulado a estudar a trajetória do STN, o que acredito ter dado um viés mais aplicado ao trabalho. Aos parceiros dessa época, deixo meu agradecimento na figura do Sylvio Petrus, que me apoiou enormemente na tarefa de conciliar meu tempo entre a atividade profissional e a pós-graduação.

Além disso tudo, esse trabalho só pode ser concluído porque contou com a inestimável ajuda da queridíssima Lara Freitas, que se dispôs a rever o meu português mal acabado. Se algum erro sobrou, foi por teimosia minha e não por falta de alerta seu.

Aos amigos de longa, média e recente data, meu obrigado também por fazarem desse percurso uma caminhada mais leve e não terem desistido de mim, apesar dos constantes furos: Pedro Schaffa, André Pitta, Gady Saiovici, João Fellet, Eduardo Brodsky, Rubens Park, Rafael Guandaline, Aderbal Neto, Renato Rosemberg, Ticiana Nogueira, Ana Carolina Carvalho e tantos mais.

Finalmente, essa dissertação não seria possível sem o suporte incomensurável da minha querida família. Por isso agradeço:

À matriarca do clã, Dra. Maria Helena Leite Ribeiro, a quem eu devo tudo. 
Ao meu pai, Sr. Toninho, ao meu irmãozinho, Renato, à minha irmã postiça, Maria Alba, e à minha Vó Ernesta, que desde 2004 não está mais por aqui. A todos eles, por serem os pontos de referência que são para mim.

Ao Dr. Hugo, meu avô, por ser esse jovem idealista, essa rocha dura, inflexível e perseverante que desde a infância é um exemplo pra mim. 


\section{RESUMO}

O propósito deste trabalho é analisar a regulação jurídica brasileira da intervenção do Estado, por meio da tributação, sobre a economia. Esta tarefa se desenvolve em três momentos - teórico, dogmático e histórico/institucional - que se estendem ao longo dos três capítulos do trabalho, respectivamente. O primeiro momento lida com a dimensão doutrinária jurídica de análise, interpretação, metodologia e abordagem deste fenômeno. Buscamos recuperar historicamente a trajetória da doutrina do direito tributário brasileiro em contraposição à doutrina do direito econômico brasileiro, recuperando o conceito de extrafiscalidade como ponto limite da doutrina tributária e ponto de partida para uma análise sistemática da intervenção estatal pela tributação. $\mathrm{O}$ segundo momento é a tentativa de traçar uma abordagem pertinente para essa análise da extrafiscalidade tributária pelo direito econômico, problematizando-a à luz do ordenamento brasileiro, sobretudo, em nível constitucional. Para tanto, assumimos as categorias de Eros Roberto Grau, sobre a intervenção estatal na economia, e as de Richard A. Musgrave, sobre as finalidades da política fiscal, para aprofundarmos a classificação do fenômeno quanto à sua forma (indução), suas técnicas (oneratórias/ desoneratórias), suas finalidades (extrafiscalidade alocativa/ extrafiscalidade distributiva/ extrafiscalidade estabilizadora) e seu regime de competências. O terceiro momento remonta um panorama da evolução histórica do sistema tributário nacional, seus principais diplomas normativos, encadeado em uma narrativa que envolve os atores, interesses, ideias e modelos institucionais e jurídicos adotados pelo Brasil, principalmente em torno do federalismo fiscal. Por fim, concluímos haver uma tendência à separação progressiva do regime jurídico da físcalidade e da extrafiscalidade, por conta da própria trajetória econômica, política, histórica, normativa e institucional do sistema tributário brasileiro. Fato diante do qual resta ao conhecimento jurídico, como saber tecnológico que é, reconhecer, compreender, se aprofundar e performar.

Palavras-chave: Extrafiscalidade, intervenção econômica, direito econômico, federalismo fiscal brasileiro, sistema tributário brasileiro, política econômica e política tributária. 


\section{ABSTRACT}

The purpose of this paper is to analyze the legal regulation of the Brazilian state intervention through taxation on the economy. This task is unfolded in three parts theoretical, dogmatic and historical/ institutional - that are developed in the three chapters of the work, respectively. The first deals with the doctrinal legal dimension of analysis, interpretation, methodology and approach of this phenomenon. We seek to recover the historical trajectory of the Brazilian tax law doctrine in contrast with the Brazilian economic law doctrine, recovering the concept of taxation based on police powers as a threshold point of the tax law doctrine and a starting point for a systematic analysis of state intervention through taxation. The second part is an attempt to draw a pertinent approach to the analysis of the taxation based on police powers by the economic law doctrine, questioning it under the lens of the Brazilian legal system, especially at the constitutional level. Therefore, we assume Eros Roberto Grau's categories about the state intervention in the economy, and Richard A. Musgrave's categories about the aims of fiscal policy, to further classify the phenomenon by its shape (induction), its techniques (overtax/ exonerate), its purposes (allocative/ distributive/ stabilizer) and its regime of competence. The third part is an overview of the historical evolution of the Brazilian tax system, its main laws and regulatory instruments, through a narrative that involves actors, interests, ideas, and institutional and legal models adopted by Brazil, particularly around fiscal federalism. Finally, we conclude that there is a tendency to a progressive separation between the legal regime of taxation based on revenues and of the legal regime of taxation based on police powers because of the economic, political, historical, normative and institutional trajectory of the Brazilian tax system. As a consequence of that, we believe that legal thought should, as technological knowhow, recognize this fact, understand it, deepen it and perform it.

Keywords: Taxation based on police powers, economic intervention, economic law, Brazilian fiscal federalism, Brazilian tax system, economic policy, tax policy. 


\title{
LISTA DE ABREVIATURAS
}

\author{
ADIN - Ação Direta de Inconstitucionalidade \\ CF - Constituição Federal
}

COFINS - Contribuição Social para Financiamento da Seguridade Social

CPMF - Contribuição Provisória sobre Movimentação ou Transmissão de Valores e de Créditos e Direitos de Natureza Financeira

CSLL - Contribuição Social sobre o Lucro Líquido

CTN - Código Tributário Nacional

FNE - Fundo de Constitucional de Financiamento do Nordeste

FNO - Fundo de Constitucional de Financiamento do Norte

FPE - Fundo de Participação dos Estados

FPM - Fundo de Participação dos Municípios

ICM - Imposto sobre a Circulação de Mercadorias

ICMS - Imposto sobre a Circulação de Mercadorias e Serviços e Prestação de Serviços de transportes Interestadual, Intermunicipal e de Comunicação

IE - Imposto sobre Exportações

IEE - Imposto sobre Energia Elétrica

IGF - Imposto sobre Grandes Fortunas

II - Imposto sobre Importações

IOF - Imposto sobre Operações Financeiras

IPI - Imposto sobre Produtos Industrializados

IPTU - Imposto sobre a Propriedade Predial e Territorial Urbana

IPVA - Imposto sobre a Propriedade de Veículos Automotores

IR - Imposto sobre a Renda e Proventos de Qualquer Natureza

IRPF - Imposto sobre a Renda e Proventos de Qualquer Natureza de Pessoa Física 
IRPJ - Imposto sobre a Renda e Proventos de Qualquer Natureza de Pessoa Jurídica ISS - Imposto sobre Serviços de Qualquer Natureza

ITBI - Imposto sobre Transmissão de Bens Imóveis

ITCMD - Imposto de Transmissão de Bens e Direitos Causa Mortis e Doação

ITR - Imposto sobre Propriedade Territorial Rural

ITR - Imposto sobre Transportes

IULCLG - Imposto Único sobre Lubrificantes e Combustíveis Líquidos e Gasosos

IUM - Imposto Único sobre Minerais

IVC - Imposto sobre Vendas e Consignações

PAES - Programa de Parcelamento Especial

PAEG - Plano de Ação Econômica do Governo

PASEP - Programa de Formação do Patrimônio do Funcionário Público

PEC - Proposta de Emenda à Constituição

PIS - Programa de Integração Social

REFIS - Programa de Recuperação Fiscal 


\section{SUMÁRIO}

INTRODUÇÃO

\section{AS PERSPECTIVAS DO DIREITO TRIBUTÁRIO E DO} DIREITO ECONÔMICO SOBRE A TRIBUTAÇÃO............................25

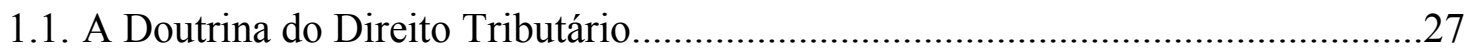

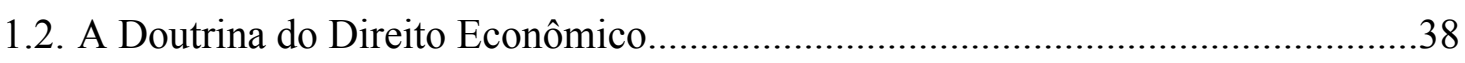

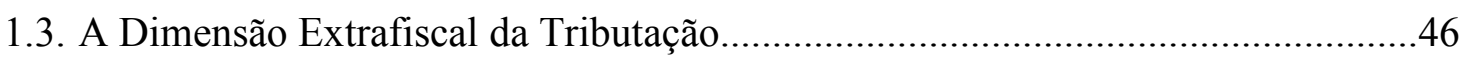

1.3.1. O Conceito de Extrafiscalidade no Direito Tributário..................................46

1.3.1.1. Externalidade e Extrafiscalidade................................................50

1.3.2. A Extrafiscalidade enquanto objeto do Direito Econômico...........................53

\section{DOGMÁTICA DA INTERVENÇÃO ECONÔMICA}

DO ESTADO PELA TRIBUTAÇÃO......................................................57

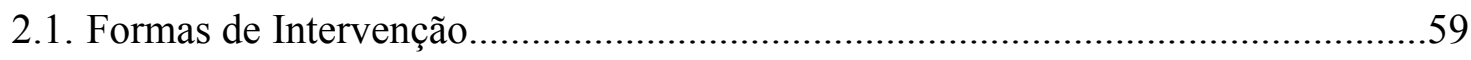

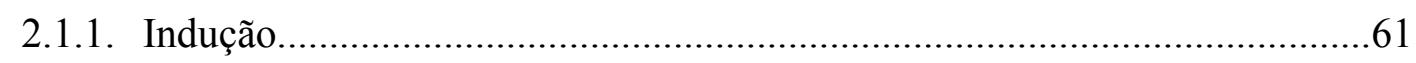

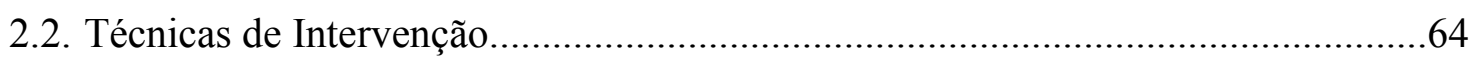

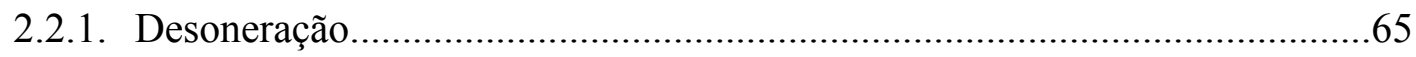

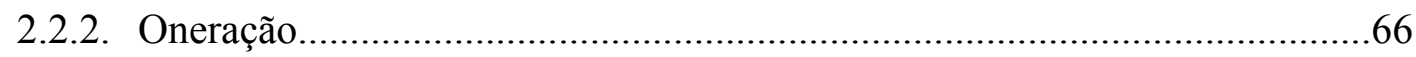

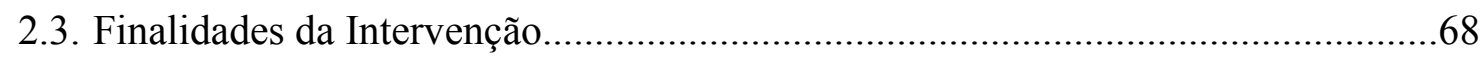

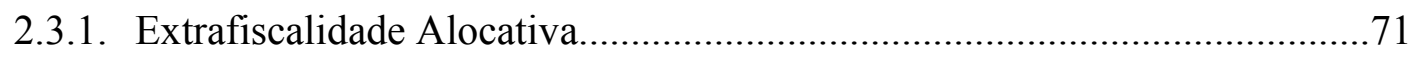

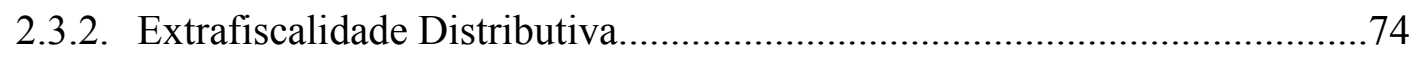

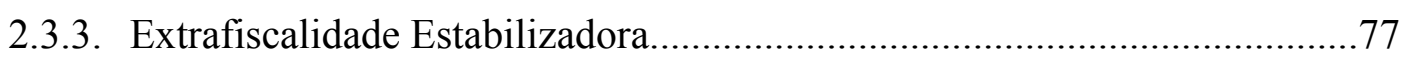

2.4. Competências para Tributar e Capacidade de Intervenção Extrafiscal....................80 


\section{ESTRUTURA JURÍDICA DO SISTEMA}

TRIBUTÁRIO BRASILEIRO_.................................................................887

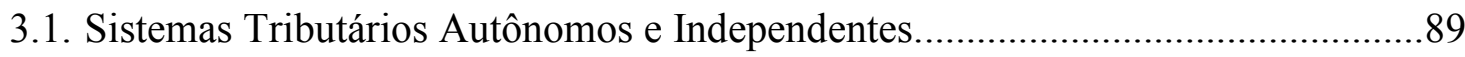

3.1.1. Evolução das Fontes de Financiamento.....................................................89

3.1.2. Evolução do Federalismo Fiscal..............................................................93

3.2. A Construção de um Sistema Tributário Nacional...............................................99

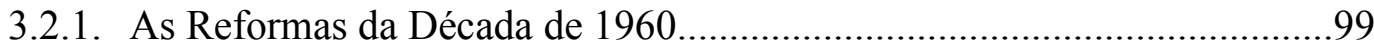

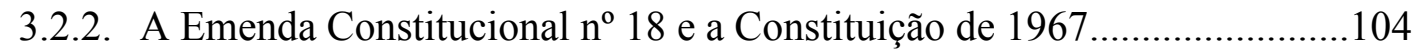

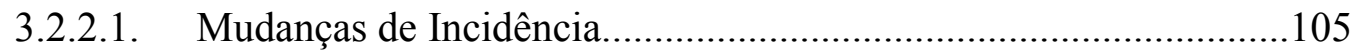

3.2.2.2. Mudanças de Competência..........................................................109

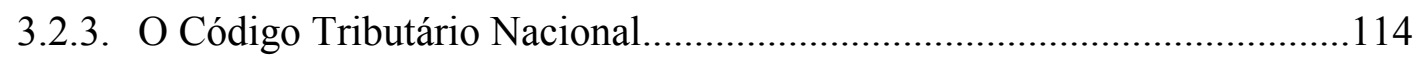

3.3. Reequilíbrio Federativo: Dependência Jurídica com Autonomia Econômica......117

3.3.1. Constituição de 1988 e Fragmentação do Sistema....................................117

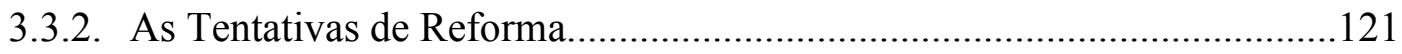

CONCLUSÃO_.......................................................................................130

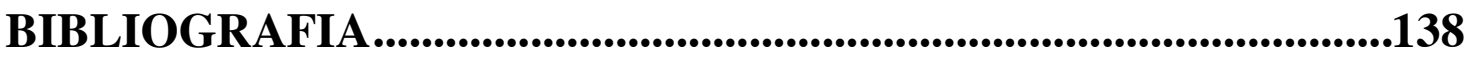


“Os tributos não só ajudaram a criar o Estado. Eles ajudaram a formá-lo. O sistema tributário foi o órgão cujo desenvolvimento estruturou os demais. Com a fatura tributária em mãos, o Estado penetrou as economias particulares $e$ ganhou crescente domínio sobre elas. (...) O tipo e o nível de tributos são determinados pela estrutura social, mas uma vez que eles existem tornam-se uma alça, por assim dizer, que as forças sociais podem agarrar a fim de mudar essa estrutura."

\section{( J. Schumpeter)}

"(...) a concurrent jurisdiction in the article of taxation was the only admissible substitute for an entire subordination, in respect to this branch of power, of state authority to that of the union. Any separation of the objects of revenue that could have been fallen upon, would have amounted to a sacrifice of the great interests of the union to the power of the individual states." 


\section{INTRODUÇÃO}

Antes de se mudar para os Estados Unidos em 1932, se estabelecer como professor de economia de prestígio em Harvard e um dos maiores economistas do século XX, Joseph Schumpeter viveu uma intensa vida acadêmica e política na Viena do início do século XX. ${ }^{2}$

Em 1918, Schumpeter escreve um de seus artigos mais importantes deste período, The Crises of the Tax State, em que se debruça sobre os problemas da economia austríaca após a primeira guerra mundial, refletindo a respeito do papel da política fiscal e da tributação no Estado moderno, bem como da economia de livre mercado. Para ele, o Estado moderno se caracterizava, justamente, pelo regime da livre iniciativa econômica e de financiamento tributário do Estado. ${ }^{3}$

$\mathrm{Na}$ visão de Schumpeter, a tributação seria a contra-face estatal de uma economia organizada pela iniciativa privada, o que imporia limites ao potencial fiscal do Estado que não poderia inverter a própria lógica da busca pelo interesse individual. ${ }^{4}$

Entretanto, para o autor, as tendências de uma economia totalmente administrada pelo Estado colocavam em questão a eventual superação desse Estado tributário. $\mathrm{O}$ financiamento do estatal já não estava limitado às receitas derivadas, sobretudo porque ele podia criar sua própria esfera econômica, assumindo a iniciativa pública empresarial em substituição à iniciativa privada. ${ }^{5}$ É diante dessa possível tendência, da intervenção direta do Estado na economia, assumindo a iniciativa econômica, que Schumpeter vê na defesa do "Estado Tributário" também uma defesa da economia de

\footnotetext{
${ }^{2}$ Em março de 1919 ele aceitou o convite para ser ministro das finanças do novo governo austríaco, liderado por Karl Renner e composto por uma coalisão entre do partido Social Democrata, o partido da Democracia Cristã e o partido Conservador Católico. Segundo Richard Swedberg, foi por sugestão dos marxistas Otto Bauer e Rudolf Hilferding, que conheciam Schumpeter da Universidade de Viena, que o convite foi feito. O governo de coalizão buscava um quadro técnico para assumir a pasta. A situação fisscal da Áustria era gravíssima. Seu plano para enfrentar a crise passava por importar capital, estabilizar a moeda e taxar o capital. A despeito das causas, há um razoável consenso de que seu ministério não foi bem sucedido. Vide: SCHUMPETER, Joseph Alois. The Economics and Sociology of Capitalism. Ed: Richard Swedberg. New Jersey: Princeton University Press, 1991, p. 15.

${ }^{3}$ Ibidem, p. 108.

${ }^{4}$ Ibidem, p. 112. "In this world the state lives as an economic parasite. It can withdraw from the private economy only as much as is consistent with the continued existence of this individual interest in every particular socio-psychological situation."

${ }^{5}$ Ibidem, p. 116.
} 
livre iniciativa em contraposição a uma economia amplamente administrada pelo Estado. ${ }^{6}$

Nesse sentido, Schumpeter aponta para a manipulação do instrumento tributário como alternativa de política econômica para a superação da crise austríaca, principalmente por seus efeitos sobre a estabilização da economia, atacando o problema do descompasso entre o valor da moeda e da riqueza nacional criado com a primeira guerra mundial. ${ }^{7}$ Para ele, apostar numa saída pela tributação era apostar em um modelo que mantinha as rédeas do processo econômico nas mãos da iniciativa privada de empresários racionais e maximizadores. ${ }^{8}$

Quase 20 anos após a publicação deste artigo, John Maynard Keynes, outro dos maiores economistas do século XX, publicou sua clássica obra Teoria Geral do Emprego do Juro e da Moeda. Olhando para a grande depressão econômica da época, ele asseverava que os maiores problemas da sociedade eram sua incapacidade de proporcionar o pleno emprego e uma divisão equitativa dos rendimentos. ${ }^{9}$

As causas do desemprego involuntário, a seu ver, muitas vezes residiam em uma deficiência de demanda que poderia ser combatida com políticas adotadas pelo governo que a elevassem, atuando direta e rapidamente sobre o desemprego involuntário. ${ }^{10} \mathrm{~A}$ desigualdade, por outro lado, poderia ser enfrentada com uma expansão da tributação direta sobre rendimentos e heranças, que por uma crença equivocada de que sua

\footnotetext{
${ }^{6}$ Ibidem, pp. 116 e 130.

${ }^{7}$ Ibidem, p. 123.

${ }^{8}$ Ibidem, p. 130. A esse respeito argumenta ainda: "It is not intended as an apotheosis of the free economy as the last word of wisdom. I am not in the habit of crowning our bourgeoisie with laurel wreaths. However, it can do exactly what is needed now. No recognition of its narrowness and cultural poverty detracts from this fact. Marx himself, if he lived today, could not be of a different opinion. And he would laugh grimly at those of his disciples who welcome the present administrative economy as the dawn of socialism-that administrative economy which is the most undemocratic thing there is, that step back to what preceded the competitive economy which alone can create the preconditions for true socialism and finally evolve socialism itself. The social form of the society of the future cannot grow out of an impoverished economy thrown backward in its development, nor out of instincts run wild. It has been the tragedy of all attempts to realize the new social order, most recently of the Russian one, that people could be won over only when whipped up by dire need and when a situation existed in which true success could not be hoped for-a situation which precisely the bourgeois businessman with precisely his mentality and precisely his experiences and methods could meet successfully."

9 KEYNES, John Maynard. A Teoria Geral do Emprego, do Juro e da Moeda. Trad. Mário R. da Cruz. São Paulo: Atlas, 1992, p. 339.

${ }^{10}$ KRUGMAN, Paul. Prefácio In: KEYNES, John Maynard. A Teoria Geral do Emprego, do Juro e da Moeda. Trad. Mário R. da Cruz. São Paulo: Atlas, 1992, p. X.
} 
utilização excessiva poderia reduzir os investimentos, acabavam por serem subutilizados. ${ }^{11}$

O Estado deverá exercer uma influência orientadora sobre a propensão ao consumo, em parte mediante o sistema de tributação, em parte por meio da fixação da taxa de juro e, em parte, eventualmente, por outros meios. (...)Não é a propriedade dos instrumentos de produção que importa ao Estado assumir. Se o Estado estiver em condições de determinar o montante agregado dos recursos destinados a aumentar esses instrumentos e a taxa básica de remuneração de seus detentores, terá realizado tudo o que é necessário. ${ }^{12}$

Nesse sentido, Avelãs Nunes comenta que Keynes via a necessidade de uma intervenção mais ampla e coordenada do Estado, por meio de uma política fiscal, como forma de estabilizar as flutuações da economia. ${ }^{13}$

Diante desses fragmentos dos trabalhos de dois dos maiores economistas do século XX, fica evidente que além das formas diretas de intervenção econômica, por meio de empresas estatais ou de normas de direção sobre o mercado, também está à disposição do Estado formas indiretas de intervenção econômica, como a manipulação de instrumentos com potencial de induzir o comportamento dos agentes no mercado, fazendo com que os interesses individuais convirjam para o interesse econômico do Estado.

Embora a utilização dos tributos como instrumento de uma intervenção indireta do Estado na economia não seja uma inovação do século XX, é inegável que ela só se tornou um traço central da gestão macroeconômica dos países nesse período. Longe de ser uma prática episódica, sua utilização passou a ser constante. O que deixa claro também como a condução de uma política tributária - uma ação orientada e planejada para a arrecadação do Estado - é um dos grandes instrumentos de política econômica de que dispõe os Estados. ${ }^{14}$

11 KEYNES, John Maynard. op. cit., p. 339.“Desde o fim do século XIX, conseguiu-se um significativo progresso na redução das grandes desigualdades de riqueza e de rendimento mediante a tributação direta impostos sobre o rendimento, imposto complementar e impostos sucessórios -, especialmente na GrãBretanha. Muitos desejariam que se levasse esse processo bastante mais longe, mas são dissuadidos por duas considerações. Em parte, pelo receio de tornar demasiado vantajosas certas hábeis evasões fiscais e, também, pelo medo de enfraquecer excessivamente as motivações para a tomada de riscos."

${ }^{12}$ Ibidem, p. 344.

${ }^{13}$ NUNES, Antonio José Avelãs. Uma Introdução À Economia Política. São Paulo: Quartier Latin, 2007, pp. 586-587.

${ }^{14}$ Nesse sentido que Paul Samuelson afirma que os principais instrumentos a serviço da política econômica são a política monetária e a política fiscal, que envolve a tributação e o gasto público. In: SAMUELSON, 
A tributação é meio de financiamento do Estado e de organização da atividade econômica. Sua dupla instrumentalidade é notória. ${ }^{15}$ Não por outra razão, a grande maioria dos sistemas tributários é dotada de tributos sobre distintas áreas da economia como o consumo, o comércio exterior, a renda e a propriedade. A pretexto de financiar suas atividades e políticas públicas essenciais, o Estado regula o funcionamento da economia de mercado, induzindo e incentivando setores e condutas, acumulando e redistribuindo renda, por meio da imposição de uma tributação mais onerosa ou mais branda.

A estrutura tributária de um país revela as fontes de financiamento e de formação do fundo público estatal, assim como a potencial renúncia fiscal revela um poderoso instrumento de intervenção econômica. ${ }^{16}$ A repercussão econômica dessas normas nos demonstra qual a divisão social do ônus fiscal, a repartição de competências entre os entes estatais e a extensão da presença ou da ausência do Estado em uma dada economia.

Geraldo Biasoto Jr. afirma que a análise da questão tributária se apresenta em diversas dimensões, dentre as quais a capacidade de extrair recursos da sociedade é apenas uma delas. No caso brasileiro, a seu ver, os desafios que se assentam sobre o sistema tributário atual se articulam em pelo menos quatro grandes tensões: a competitividade de sua economia no mercado interno e externo, a divisão de competências do federalismo brasileiro, as pressões sociais em torno do financiamento de direitos econômicos e, por fim, o papel regulador da inserção estatal na economia e sua capacidade de articular os setores dinâmicos, grupos e forças. ${ }^{17}$

Paul. A.; Nordhaus, William D. Economics. 18 ed. Boston; New York: McGraw-Hill, 2005, p. 411-414. Apud in: BERCOVICI, Gilberto. Política Econômica e direito econômico. In: Revista Fórum Direito Financeiro e Econômico - RFDFE I Belo Horizonte, ano I, n ${ }^{0}$ 1, mar/ago 2012, p. 199.

${ }_{15}$ Para o conceito de dupla instrumentalidade, originariamente formulado por Norbert Reich, ver: BERCOVICI, Gilberto. O Ainda Indispensável Direito Econômico. In: BENEVIDES, Maria Victoria de Mesquita; BERCOVICI, Gilberto; MELO, Claudineu de. Direitos Humanos, Democracia e República: Homenagem a Fabio Konder Comparato. São Paulo: Quartier Latin, 2009, p. 518.

${ }^{16}$ BIASOTO JÚNIOR, Geraldo. O Sistema Tributário Brasileiro: uma Trajetória de Fragmentação. In: BIASOTO JÚNIOR, Geraldo e PINTO, Márcio Percival Alves (orgs.). Política Fiscal e Desenvolvimento no Brasil. Campinas: Editora Unicamp, 2006, p. 45.

${ }^{17}$ Ibidem, pp. 41-42. 
De forma semelhante, Richard A. Musgrave sustenta que o papel fiscal do Estado deva ser compreendido em três grandes categorias: alocativa, distributiva e estabilizadora. ${ }^{18}$

A primeira corresponderia à provisão de bens público pelo Estado. As instituições, serviços e bens essenciais para a sociedade e a forma pela qual serão providos. Em sua opinião, as finanças públicas, e a tributação em particular, têm uma interface significativa nesse ponto, não apenas garantindo recursos para o Estado provê-los, mas também orientando o mercado a fazê-lo por meio de incentivos e desestímulos. ${ }^{19}$

A função distributiva se reportaria à maneira como a política fiscal pode influir na distribuição da riqueza e da renda para equilibrar a acumulação de ambas em uma sociedade, na busca de um ideal de justiça. Aqui reside a capacidade da tributação e do gasto público reverterem as desigualdades de renda por meio de políticas sociais típicas de um Estado de bem-estar social. ${ }^{20}$

Por fim, a função estabilizadora se caracterizaria pelo papel desempenhado pela política fiscal enquanto política macroeconômica, inspirado inegavelmente no modelo econômico keynesiano. ${ }^{21}$ A contribuição da política fiscal, entre outros, por meio da manipulação dos instrumentos tributários, na estabilização da política monetária, na busca pelo pleno emprego, na composição da balança comercial e em seu impacto sobre o crescimento econômico. O controle da demanda agregada e da diferença entre o consumo e o investimento social. ${ }^{22}$

Entretanto, a intervenção sobre o domínio econômico por meio da tributação talvez seja a seara mais intrincada juridicamente para a condução da política econômica. Isso porque tal prerrogativa estatal, de exigir uma prestação pecuniária compulsória que não constitui sanção de ato ilícito, ${ }^{23}$ é cercada de um emaranhado de normas que restringe o exercício desse poder.

\footnotetext{
${ }^{18}$ MUSGRAVE, Richard. A. Teoria das Finanças Públicas: Um Estudo de Economia Governamental. Trad: Auriphebo Berrance Simões. Vol 1. São Paulo: Atlas, 1973.

${ }^{19}$ Ibidem, p. 6. Ver também: BUCHANAN, James M. e MUSGRAVE, Richard A. Public Finance and Public Choice: Two Contrasting Visions of the State. Cambridge: MIT Press, 1999, pp. 37, 38 e 40.

${ }^{20}$ Ibidem, pp. 6. Ver também: Ibidem, pp. 43-46.

${ }^{21}$ Ibidem, pp. 6. Ver também: Ibidem, pp. 47.

${ }^{22}$ Ibidem, pp. 6. Ver também: Ibidem, pp. 49.

${ }^{23}$ Vide artigo $3^{\text {o }}$ do CTN. In: BRASIL. Lei n ${ }^{\circ} 5.172$, de 25 de outubro de 1966. Dispõe sobre o Sistema Tributário Nacional e institui norma gerais de direito tributário aplicáveis à União, Estados e Municípios. In: Vade Mecum Tributário e Financeiro. Florianópolis: Conceito, 2010. Organização do texto: João Batista Lazzari et al.
} 
Como alerta Rogério Leite Lobo, não se pode esquecer que no aspecto estrutural a execução da política tributária encontrará obstáculos intransponíveis fincados pelas regras jurídicas que controlam o exercício desse poder estatal. Especialmente, no caso brasileiro em que a Constituição estabelece um capítulo do Sistema Tributário Nacional, cuja rigidez é uma das principais características. ${ }^{24}$

De tal sorte, a condução de uma política tributária não pode prescindir de um conhecimento sólido dos limites impostos pelo direito tributário no momento de elaboração de seu planejamento. Um exemplo disso são as chamadas limitações ao poder de tributar, que vão desde a observância da estrita legalidade, de imunidades constitucionais, da anterioridade entre a promulgação da lei e sua produção de efeitos jurídicos, até a necessidade de precisa delimitação das condutas passíveis de tributação.

Todavia, embora componha parte essencial para a compreensão do quadro geral da tributação, o papel do direito não se resume a limitar o exercício do poder estatal de tributar, pois também lhe incumbe viabilizar e legitimar o seu exercício. De tal maneira que não apenas os meios utilizados pela política fiscal são regulados pelo direito, mas também os fins perseguidos e alcançados são por ele definidos e passíveis de análise jurídica.

Parece-nos claro, portanto, que o estudo da intervenção do Estado na economia, pela tributação, deva ser feito pelo Direito Econômico. Sobretudo porque envolve a utilização dos tributos como instrumentos de execução da política econômica. Nesse sentido, é pertinente resgatar a própria definição de Fábio Konder Comparato, para quem:

O nôvo direito econômico surge como o conjunto de técnicas de que lança mão o Estado contemporâneo na realização de sua política econômica. Êle constitui assim a disciplina normativa da ação estatal sôbre as estruturas do sistema econômico. $^{25}$

Tendo em vista esta observação, buscamos, nas páginas seguintes, efetuar uma análise do sistema tributário brasileiro sob a perspectiva do direito econômico,

\footnotetext{
${ }^{24}$ LOBO, Rogério Leite. Os Atos de Tributação Interventivos no Domínio Econômico: Proposta de Classificação e Considerações sobre o seu Regime Jurídico. In: Revista de Direito Administrativo, Vol. 232, Rio de Janeiro, 2003, p. 33.

${ }^{25}$ COMPARATO, Fábio Konder. O indispensável Direito Econômico. In: Revista dos Tribunais. Ano 54. Vol. 353, São Paulo, 1965, p. 22.
} 
considerando sua capacidade de ser instrumento de execução da política econômica do Estado brasileiro e as tensões que envolvem a política tributária no país.

Portanto, a rigor, o objeto desta pesquisa são as tensões entre as finalidades fiscais e extrafiscais $^{26}$ da tributação brasileira, inscritas nas normas tributárias. Trata-se de compreender como a tributação, enquanto instrumento de financiamento do gasto público e enquanto instrumento de política econômica, é regulada pelo direito.

Essa análise do direito tributário enquanto veículo de políticas econômicas, por sua vez, exigirá a sistematização das finalidades extrafiscais abarcadas pelo ordenamento jurídico brasileiro e do regime de competências para execução dessa manipulação instrumental dos tributos. Debates que nos levarão a problematizar os princípios e objetivos da intervenção econômica do Estado brasileiro, consagrados na constituição econômica dirigente de 1988, e as nuances de nosso pacto federativo, desde a sua formação, na constituinte de 1891, até o presente momento.

Um dos perigos que rondam a abordagem dessas questões é nos enveredarmos por um debate jurídico teórico e idealista, resultando numa espécie de "tratadismo" sem vínculo com a realidade. Alerta esse que Francisco de Oliveira bem registrou:

\begin{abstract}
A federação somente aparece em tratadistas, no campo do direito constitucional, do direito administrativo, e com mais força, no direito tributário. Mas tratadistas não elaboram ideologias hegemônicas, embora possam formalizá-las. Os economistas especializados em fiscalidade são as mais recentes incorporações à legião de "tratadistas."27
\end{abstract}

A perspectiva histórica, nesse ponto, será fundamental para evitar que tomemos esse desvio, pois ensejará uma compreensão ampla do direito positivo brasileiro, contextualizado como mais um elemento da realidade social. O que nos permitirá iluminar os caminhos particulares que foram seguidos na construção do nosso sistema tributário enquanto um instrumento de política econômica. Pois, como lembra Gilberto

\footnotetext{
${ }^{26}$ PAULSEN, Leandro. Direito Tributário: Constituição e Código Tributário à luz da Doutrina e da Jurisprudência. Porto Alegre: Esmafe, 2009, p. 15. É consagrada na doutrina jurídica a distinção conceitual de que toda norma tributária pode motivar-se por finalidades fiscais (a arrecadação de recursos) ou extrafiscais (efeitos diversos produzidos pela norma, de caráter econômico ou social). Embora no plano real jamais seja possível empreendermos esta clivagem com precisão, trata-se de uma distinção útil do ponto de vista jurídico, pois no permite separar duas dimensões da tributação - enquanto instrumento de arrecadação fiscal e de política econômica - e que, portanto, a tornam regulada pelos limites ao poder de tributar e pela ordem econômica.

27 OLIVEIRA, Francisco de, A Crise da Federação: da Oligarquia à Globalização. In: ÁLVAREZ AFFONSO, Rui Britto; e BARROS SILVA, Pedro Luiz. (orgs.). A Federação em Perspectiva: Ensaios Selecionados. São Paulo: Fundap, 1995, p. 78
} 
Bercovici, a política econômica no Brasil, e consequentemente seus instrumentos, necessariamente responde aos anseios de desenvolvimento do país, e não apenas aos de estabilização macroeconômica:

\begin{abstract}
No centro do sistema econômico mundial, o direito econômico substituiu, de certo modo, o direito privado e a lógica da codificação como instrumento jurídico garantidor da estabilidade do sistema (...). Já na periferia do sistema capitalista, o direito econômico se estabelece com o desenvolvimentismo e o início do processo de industrialização, na década de $1930 .^{28}$
\end{abstract}

A capacidade de execução de uma política tributária que assuma a sua tarefa de induzir o desenvolvimento, ao invés de reparos paliativos, exige a superação dos conflitos federativos e da coordenação da política econômica nacional. Portanto, também não nos furtaremos de um horizonte prospectivo de interpretação das alternativas para os impasses do sistema tributário brasileiro, estejam elas inscritas ou não no ordenamento nacional. Tarefa essa que foi sintetizada por Fábio Konder Comparato, para quem cumpre à reflexão jurídica a capacidade de escolher e de aprimorar as instituições existentes, ou de criar outras novas, em função de objetivos que lhe são propostos pelas necessidades da vida quotidiana. ${ }^{29}$

${ }^{28}$ BERCOVICI, Gilberto. op. cit. 2012, p. 210.

${ }^{29}$ COMPARATO, Fábio Konder., op. cit., p. 25. 


\section{AS PERSPECTIVAS DO DIREITO TRIBUTÁRIO E DO DIREITO ECONÔMICO SOBRE A TRIBUTAÇÃO}

A doutrina do direito tributário e a doutrina do direito econômico, especialmente no caso brasileiro, assumiram trajetórias de desenvolvimento diametralmente opostas. Enquanto a dogmática do direito tributário se voltou para a descrição formal das normas jurídicas tributárias, ${ }^{30}$ assumindo uma matriz marcadamente kelseniana de análise, a dogmática do direito econômico se voltou para a descrição do conteúdo econômico das normas jurídicas, assumindo uma matriz marcadamente funcional de análise.

Disso temos que embora ambas as disciplinas possam vir a se debruçar sobre o mesmo objeto - na análise de instrumentos tributários que veiculem políticas econômicas - suas diferenças de perspectiva e de método sempre serão abissais.

Porque se de um lado a doutrina do direito tributário se volta para a tipologia dos tributos e o regime jurídico das relações tributárias entre o Estado e o contribuinte, de outro, a doutrina do direito econômico estuda as formas de intervenção econômica estatal por meio da tributação pela análise das políticas econômicas por elas implementadas.

Mais do que isso, as duas disciplinas lidam com situações e relações jurídicas muito díspares. Enquanto a doutrina do direito tributário tende a se ocupar das relações jurídicas entre o Fisco e o cidadão, ${ }^{31}$ derivadas das normas tributárias, a doutrina do direito econômico tende a se ocupar das relações entre o Estado e toda comunidade econômica, derivadas das mesmas normas tributárias.

\footnotetext{
${ }^{30}$ CARVAlHO, Paulo de Barros. Curso de Direito Tributário. $23^{\mathrm{a}}$ ed. São Paulo: Saraiva, 2011, p. 47. Nas palavras de Paulo de Barros Carvalho: "Estamos em que o direito tributário positivo é o ramo didaticamente autônomo do direito, integrado pelo conjunto das proposições jurídico-normativas que correspondam, direta ou indiretamente, à instituição, arrecadação e fiscalização de tributos. Compete à Ciência do Direito Tributário descrever esse objeto, expedindo proposições declarativas que nos permitam conhecer as articulações lógicas e o conteúdo orgânico desse núcleo normativo, dentro de uma concepção unitária do sistema jurídico vigente."

${ }^{31}$ ATALIBA, Geraldo. Sistema Constitucional Tributário Brasileiro. São Paulo: Revista dos Tribunais, 1968, p. 41
} 
A dogmática jurídica tributária tradicional é de grande valia na proteção de direitos e garantias dos cidadãos perante o Estado, no exercício de seu poder de invadir as esferas patrimoniais para financiar atividades de interesse público. Entretanto, é insuficiente para lidar com as consequências jurídicas dos reflexos econômicos das normas tributárias, quando tal prerrogativa é lançada com o intuito de estimular ou coibir condutas, buscando finalidades mediatas que não a arrecadação de recursos.

Nesse momento é que a metodologia do direito econômico se revela útil e necessária, na análise das políticas implementadas pelas normas tributárias, no que foi classificado como a dimensão extrafiscal da tributação. Não apenas porque a manipulação instrumental da tributação constitui a execução da política econômica do Estado e, por conseguinte, manifestação do direito econômico, mas também porque a teoria jurídica tradicional não dá conta dessa manipulação instrumental. Faltam-lhe instrumentos metodológicos que a tornem apta a considerar variáveis de perfil funcional como a eficiência, o caráter distributivo e os efeitos gerados por essas normas. ${ }^{32}$

Acreditamos, porém, que essas diferenças, mais do que nos conduzir a um embate doutrinário infrutífero, abrem caminho para a complementaridade de análise de múltiplos aspectos das normas que fixam a tributação. A dogmática do direito tributário tratando o regime jurídico que regra as limitações ao exercício deste poder em relação aos contribuintes, e o direito econômico voltado para as formas de aplicação e finalidades do exercício deste poder em relação à economia. Ambas, evidentemente, sob o amparo dos ditames constitucionais.

Ao longo deste capítulo buscamos remontar historicamente o desenvolvimento dessas duas tradições jurídicas, suas abordagens, métodos, características e diferenças que as singularizaram. Posteriormente, passamos a uma análise mais detida do conceito da finalidade extrafiscal da tributação, seu tratamento pela doutrina do direito tributário e sua abordagem pelo direito econômico.

${ }^{32}$ CAMPOS, Dejalma de. A dimensão Jurídica do Tributo In: MARTINS, Ives Gandra (org.). Tributo uma Reflexão Multidisciplinar sobre sua Natureza. Rio de Janeiro: Forense, 2007, p. 252. Segundo Dejalma de Campos: "O Direito é um dogma. Temos que receber o mandamento jurídico sem discuti-lo. A obrigação do jurista, ante o Direito, é interpretá-lo, não de julgar a norma, de saber se a mesma é oportuna ou adequada." 


\section{1 - A Doutrina do Direito Tributário}

Segundo Ricardo Lobo Torres, a doutrina do direito tributário foi historicamente pautada pelas escolas de interpretação do direito, que projetaram para o campo físcal métodos próprios de compreensão do direito. ${ }^{33}$

A seu ver, de maneira esquemática, essas escolas podem ser divididas em três principais correntes, que marcam também três momentos históricos distintos da tributação: a corrente da Jurisprudência dos Conceitos, referente ao período do Estado Liberal; a corrente da Jurisprudência dos Interesses, referente ao período do Estado de Bem-Estar Social; e a corrente da Jurisprudência dos Valores, referente ao período atual, do Estado Democrático de Direito e da Sociedade de Risco. ${ }^{34}$

A primeira delas, de interpretação sistemática e conceitualista, atribuía às categorias e aos institutos jurídicos uma capacidade plena de expressar a realidade social e econômica regulada pelo direito. ${ }^{35}$ Nesse sentido, A. D. Giannini diferenciava a análise das normas de direito financeiro da análise das normas de direito tributário, buscando o significado jurídico específico destas. ${ }^{36}$

De modo que, ao privilegiar um tratamento sistemático e dogmático, consolidou um método interpretativo baseado na dedução de novos conceitos por meio de um arsenal lógico, abrindo caminho para o domínio do formalismo jurídico. ${ }^{37}$ Perspectiva essa que levou a doutrina do direito tributário, inspirada nessa corrente de interpretação, a sustentar a primazia do direito civil sobre o direito tributário, a legalidade cerrada, a ajuridicidade do princípio da capacidade contributiva e o caráter absoluto da propriedade privada. Entre seus expoentes se destacariam A. D. Giannini, Gilberto Ulhoa Canto e A. R. Sampaio Dória. ${ }^{38}$

A corrente da jurisprudência dos interesses, por sua vez, representaria uma reação à interpretação conceitualista, advogando a necessidade de uma interpretação econômica

\footnotetext{
${ }^{33}$ TORRES, Ricardo Lobo. A Chamada "Interpretação Econômica do Direito Tributário", A Lei Complementar 104 e os Limites Atuais do Planejamento Tributário. In: Revista Ciências Sociais, Vol. 7, $n^{\circ}$ 1, Rio de Janeiro, 2001, p. 30.

${ }^{34}$ Idem.

${ }^{35}$ Idem

${ }^{36}$ GIANNINI, A. D. Elementi di Diritto Finanziario, Milano, Dott. A. Giuffrè Editore, 1945, p. 4.

${ }^{37}$ ANDRADE, José Maria Arruda de. Interpretação da Norma Tributária. 1. Ed. São Paulo: MP Editora, 2006. v. 1.p. 98

${ }^{38}$ TORRES, Ricardo Lobo., op. cit., p. 30
} 
da realidade social subjacente à norma como, por exemplo, defendendo uma interpretação econômica do fato gerador do tributo. ${ }^{39}$ No campo tributário, embora tenha tido adeptos no Brasil, como Amílcar de Araújo Falcão, seu maior desenvolvimento ocorrera na Alemanha, principalmente pelo trabalho de Enno Becker, que marca também seu período áureo impulsionado pelas necessidades de receitas dos Estados devastados pela Primeira Guerra Mundial. ${ }^{40}$

Paralelamente, na Itália, se desenvolveu outra vertente inspirada nessa jurisprudência dos interesses, a chamada interpretação funcional da Escola de Pavia. Em seu legado mereceriam destaque as teses da intervenção sobre a propriedade, da autonomia do direito tributário frente ao direito civil, da função criadora do juiz e da preponderância da capacidade contributiva decorrente da realidade social dos fatos. ${ }^{41}$

Seus principais representantes foram Benvenuto Griziotti e Vanoni. Para Griziotti as abordagens política, sociológica e econômica da Ciência das Finanças deveriam andar juntas ao direito tributário, numa relação de complementariedade. ${ }^{42}$

La actividad financiera es objeto de estúdios por parte de laciencia de lasfinanzas y del derecho financeiro, que se complementan recíprocamente. La primera de estas disciplinas es la ciencia de la legislación y de la actividad finaciera, de lãs cuales estudia la esencia, las funciones y los efectos, mientras que el derecho explica la naturaleza de las normas legislativas que gobiernan la actividad financiera y los principios para su aplicación. (...) oferece conocimientos útiles para la formación de las leyes referentes a los recursos y también para su interpreteción y aplicación. ${ }^{43}$

Rubens Gomes de Souza, autor do anteprojeto do Código Tributário Nacional, embora tenha, posteriormente, manifestado uma predileção pelas posições formalistas, chegou a defender teses como a de que atos, fatos, contratos ou negócios previstos na lei tributária deveriam ser interpretados de acordo com seus efeitos econômicos e não

\footnotetext{
${ }^{39} \mathrm{Idem}$

${ }^{40}$ ANDRADE, José Maria Arruda de. Interpretação e Aplicação da Lei Tributária: da Consideração Econômica da Norma Tributária à Análise Econômica do Direito. In: Hugo de Brito Machado. (Org.). Interpretação e Aplicação da Lei Tributária. São Paulo: Editora Dialética, 2010, p. 202.

${ }^{41}$ TORRES, Ricardo Lobo., op. cit., pp. 31.

42 GRIZIOTTI, Benvenuto. Principios de Ciencia de las Finanzas. Trad. Dino Jarah, Ed. Roque Depalma, Buenos Aires, 1959, p. 13.

${ }^{43}$ Ibidem, pp. 13 e 14.
} 
de acordo com a sua forma jurídica. ${ }^{44}$ Da mesma forma, sustentou a importância de se reforçar a consideração teleológica da norma tributária no Brasil. ${ }^{45}$

A terceira escola de interpretação do direito a influenciar a doutrina do direito tributário seria a corrente de interpretação valorativa, ressurgida sob a forte influência de uma renovação kantiana da teoria geral do direito. De acordo com Ricardo Lobo Torres, a doutrina do direito tributário nela inspirada se caracterizaria por buscar harmonizar, por intermédio dos princípios gerais do direito, os conflitos entre forma e conteúdo, direito e economia, interpretação finalística e sistemática. ${ }^{46}$

Portanto, a inspiração mais recente da doutrina tributária assinalaria o afastamento do formalismo da jurisprudência dos conceitos e o sociologismo da jurisprudência dos interesses, abrindo-se para o pluralismo metodológico da jurisprudência dos valores. ${ }^{47}$ Nela os diversos métodos interpretativos - literal, histórico, lógico, sistemático e teleológico - se descortinariam conforme os casos concretos, na medida em que os valores inscritos nas normas aplicáveis a esses casos os apontarem como mais apropriados. $^{48}$

No âmbito nacional, contudo, a história da evolução da doutrina do direito tributário assume uma trajetória particular a partir da década de 1960. A despeito do quadro traçado, observa-se na doutrina brasileira o desenvolvimento de uma corrente voltada não para a construção de uma interpretação valorativa, mas para um resgate dos autores e das teses da jurisprudência dos conceitos.

Alfredo Augusto Becker, em sua Teoria Geral do Direito Tributário, publicada pela primeira vez em 1963, argumentava, de forma bastante eloquente, que o Direito

${ }^{44}$ SOUZA, Rubens Gomes de. Compêndio de Legislação Tributária: Parte Geral. $3^{\mathrm{a}}$ Ed. São Paulo, 1975, IBET, p. 79.

${ }^{45}$ ANDRADE, José Maria Arruda de. Interpretação e Aplicação da Lei Tributária: da Consideração Econômica da Norma Tributária à Análise Econômica do Direito. In: Hugo de Brito Machado. (Org.). Interpretação e Aplicação da Lei Tributária. São Paulo: Editora Dialética, 2010, p. 204.

${ }^{46}$ TORRES, Ricardo Lobo., op. cit., pp. 32-35.

${ }^{47}$ TORRES, Ricardo Lobo. Curso de Direito Financeiro e Tributário. $18^{\mathrm{a}}$ Ed. São Paulo: Renovar, 2011, p. 146.

${ }^{48}$ Ibidem, p. 151. Nesse ponto, talvez, a constatação de José Maria Arruda de Andrade se faça reveladora, ao demonstrar ser comum que os mesmos doutrinadores lancem mão da metodologia mais formalista e declaratória para verem declarada inválida uma norma tributária, e se travistam, com desenvoltura, para advogar uma hermenêutica relativizante, funcional e teleológica para verem a extensão de isenções ou imunidades. Vide: ANDRADE, José Maria Arruda de. Interpretação e Aplicação da Lei Tributária: da Consideração Econômica da Norma Tributária à Análise Econômica do Direito. In: Hugo de Brito Machado. (Org.). Interpretação e Aplicação da Lei Tributária. São Paulo: Editora Dialética, 2010, p. 204. e ANDRADE, José Maria Arruda de. Interpretação da Norma Tributária. 1. Ed. São Paulo: MP Editora, 2006. v. 1.p. 98. 
Tributário padecia de uma demência: na sanha por compreender o conteúdo tributário deste ramo do direito, os juristas perdiam de vista o aspecto jurídico da tributação e a identidade de sua reflexão.

Ao se debruçarem sobre características específicas do conteúdo tributário das normas jurídicas, as necessidades políticas e econômicas que as motivavam, perdiam os pontos de partida básicos sobre a natureza própria do direito, sua validade, vigência, eficácia e todos demais aspectos comuns a todas as normas estudados pela teoria geral do direito.

A imersão no conteúdo das normas tributárias conduzia a disciplina a uma infeliz mancebia com a Ciência das Finanças, ${ }^{49}$ confundindo os momentos de criação da lei com o da interpretação da mesma. ${ }^{50}$ Contaminando princípios e conceitos jurídicos com princípios e conceitos econômicos, financeiros, políticos e sociais. De maneira que a ciência do direito perderia sua capacidade de aplicação das normas jurídicas e resolução de problemas de ordem prática. A passagem a seguir é bastante ilustrativa dessa visão:

\begin{abstract}
A história do Direito Tributário na primeira metade deste século é a história da grande migração dos juristas para a realidade material das terras da Economia Política e Finanças Públicas.

Somente a partir de 1945, ao terminar a guerra, é que os especializados em Direito Tributário começaram a perceber que eles eram excelentes economistas e sábios financistas e hábeis político-fiscais, mas não juristas. ${ }^{51}$
\end{abstract}

Sua dureza impressiona ao criticar a escola da interpretação funcional do Direito Tributário. Alfredo Becker afirma que a proposta de uma abordagem realística e funcional do Direito Tributário, marcada por advogar uma compreensão do fenômeno financeiro pelo entrelaçamento entre os elementos político, econômico, jurídico e operativo, seria fonte de obscurantismos e equívocos típicos de tratamentos híbridos. ${ }^{52}$

\footnotetext{
${ }^{49}$ BECKER, Alfredo Augusto. Teoria Geral do Direito Tributário. $4^{\text {a }}$. Ed. São Paulo: Noses, 2007, p. 5

${ }^{50}$ Ibidem. p. 6.

${ }^{51}$ BECKER, Alfredo Augusto. Carnaval Tributário. São Paulo: Saraiva, 1989, p. 144.

${ }^{52}$ BECKER, Alfredo Augusto. Teoria Geral do Direito Tributário. 4a . Ed. São Paulo: Noses, 2007, pp. 114 e 115. Prossegue ainda afirmando: "Os quatro elementos constitutivos do ato financeiro de GRIZIOTTI são os Quatro Cavaleiros do Apocalipse que se coordenam e recompõem na sintesifinale: a destruição do Direito Tributário (destruição precisamente do que há de jurídico dentro do Direito Tributário) restando apenas o Tributário."
} 
No mesmo sentido, ao tratar da doutrina da interpretação econômica, ele repete seus brados contra o erro que seria a negação do aspecto jurídico do direito tributário. ${ }^{53}$

A saída para este manicômio tributário ${ }^{54}$ se daria, a seu ver, por meio de uma atitude mental jurídica. ${ }^{55}$ Era premente a necessidade de uma reeducação dos juristas, para um regresso aos fundamentos do direito tributário presentes na teoria geral do direito. $\mathrm{O}$ direito tributário, antes de tributário, era direito positivo, ${ }^{56}$ instrumental e sem objetivo próprio. Seu objetivo era servir a uma política e apenas esta possuiria objetivos econômicos e sociais. ${ }^{57}$

Qualquer similaridade desta perspectiva com a da Teoria Pura do Direito de Hans Kelsen não é mera coincidência. ${ }^{58} \mathrm{~A}$ inspiração é explícita, a ponto de o autor dedicar espaço, em sua Teoria Geral do Direito Tributário, para comentar as críticas recebidas pela clássica obra de Kelsen.

Para Alfredo Becker, o papel dos críticos de Kelsen deveria ter sido continuar a sua obra de purificação do direito, prosseguindo seu trabalho de esclarecimento dos conceitos fundamentais e de identificação, diferenciação e solução dos problemas. ${ }^{59}$ Sem esse horizonte, a ciência do direito acabaria por converter-se numa anárquica sociedade de tiranetes, preponentes e facciosos, cada um dos quais seguidos de seus poucos discípulos a partilhar suas pequenas descobertas. ${ }^{60}$

Paulo Caliendo argumenta que os estudos sobre direito tributário no Brasil receberam uma grande contribuição de Alfredo Augusto Becker, uma vez que este autor passou a estudar o tributo como uma espécie de norma jurídica, pelos pressupostos de Hans Kelsen e Pontes de Miranda. ${ }^{61}$ Em um segundo momento, a publicação da obra "Hipótese de Incidência Tributária”, de Geraldo Ataliba, teria dado um importante passo teórico a essa tradição, combinando a teoria de A. D. Giannini com a de Alfredo Augusto Becker.

\footnotetext{
${ }^{53}$ Ibidem, p.138

${ }^{54}$ Ibidem, p. 1 e 11.

55 Ibidem, p. 15.

${ }^{56}$ Ibidem, p. 44.

${ }^{57}$ Ibidem, p. 632.

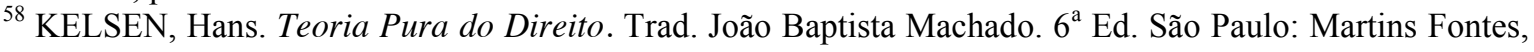
1988.

${ }^{59}$ BECKER, Alfredo Augusto, op. cit., pp. 64 e 65.

${ }^{60}$ Ibidem, p. 65.

${ }^{61}$ CALIENDO, Paulo. Direito Tributário e Análise Econômica do Direito: Uma Visão Crítica. Rio de Janeiro: Elsevier, 2009, p. 86.
} 
Nesse trabalho, Geraldo Ataliba se volta para o estudo da categoria de fato gerador e propõe uma distinção entre hipótese de incidência do tributo, a descrição hipotética e abstrata de um fato, ${ }^{62}$ e o fato imponível, fato concreto e material, cuja realização efetiva a descrição da hipótese de incidência. ${ }^{63}$

Dessa maneira, o autor rivalizava com a tese que ficou conhecida como a interpretação econômica do fato gerador, vertente surgida na Alemanha com apoio na jurisprudência dos interesses, que teve alguma receptividade no Brasil, no período da Constituição de 1946, após a $2^{\mathrm{a}}$ Guerra, nos trabalhos de Aliomar Baleeiro e Amílcar Falcão. ${ }^{64}$

Essa reconstrução do fato gerador leva Geraldo Ataliba a reafirmar a não especificidade do conteúdo do direito tributário, uma vez que o mesmo consiste em um mandamento comportamental hipotético como as demais normas jurídicas. ${ }^{65} \mathrm{O}$ seu mandamento específico, de levar dinheiro ao Estado, não singularizaria o direito tributário, pois o direito não se ocuparia do fato de o dinheiro ser levado ou não aos cofres públicos, mas sim da obrigação comportamental de levar o dinheiro. ${ }^{66}$

Embora possa parecer trivial, a mudança de perspectiva operada é profunda, pois disso decorre que o objeto da relação tributária passa a ser o comportamento consistente em levar dinheiro aos cofres públicos. Tal visão induz o autor a definir o escopo do direito tributário da seguinte maneira:

9.7 O objeto do direito tributário é o estudo do direito tributário positivo ou objetivo. O instituto jurídico central desse estudo é o tributo.

Como conceito básico, definimos tributo, instituto nuclear do direito tributário (entendido como sub-ramo do direito administrativo), como obrigação (relação jurídica). ${ }^{67}$

Se o tributo é obrigação jurídica, a tributação, para o direito tributário, passa a ser o conjunto de relações obrigacionais, decorrentes de lei, pecuniárias, que não constituem

${ }^{62}$ ATALIBA, Geraldo. Hipótese de Incidência Tributária. $6^{\text {a }}$. Ed. 13 ${ }^{\mathrm{a}}$ Tiragem. São Paulo: Malheiros, 1999 , p. 66.

${ }^{63}$ Ibidem, p. 67.

${ }^{64}$ TORRES, Ricardo Lobo. Interpretação e Integração da Lei Tributária. In: Hugo de Brito Machado. (Org.). Interpretação e Aplicação da Lei Tributária. São Paulo: Editora Dialética, 2010, p. 354.

${ }^{65}$ ATALIBA, Geraldo, op. cit., p. 21.

${ }^{66}$ Ibidem, p. 23.

${ }^{67}$ ATALIBA, Geraldo, op. cit., p. 34. 
sanção de ato ilícito, e cujos sujeitos ativos e passivos são designados pela lei, sob o amparo da constituição. ${ }^{68}$

12.7 Em torno dessa noção, se construiu a ciência do direito tributário, com autonomia didática, a qual tem por objeto o estudo do direito tributário objetivo, que se compõe das normas que regulam a tributação (ação tributária, privativamente estatal), o tributo e as relações jurídicas entre tributantes e tributados, em razão da tributação. ${ }^{69}$

Com esse movimento teórico, todas as repercussões decorrentes das normas tributárias passam a constituir objeto alheio ao direito tributário, como demarca Geraldo Ataliba:

“11.9 O tributo é, juridicamente, um instituto criado pela ordenação jurídica. Pode ou não ser semelhante aos conceitos extrajurídicos designados pela mesma palavra, em outros setores do conhecimento.

11.10 Não pode o jurista estudar as características e propriedades do tributo, senão tais como configuradas pelo direito positivo (no Brasil, constitucional). (...) Uma entidade do mundo do direito não pode ter propriedades não jurídicas. A confusão entre o pré-jurídico e o jurídico só pode conduzir a perplexidades e terríveis erronias."70

Ainda, segundo Paulo Caliendo, um derradeiro avanço significativo para o aprofundamento dessa corrente no direito tributário brasileiro ocorrera com os estudos de Paulo de Barros Carvalho. Ao publicar a "Teoria da Norma Tributária”, o autor teria mesclado o modelo de Kelsen, Becker e Ataliba com as contribuições da linguística e da semiótica, desembocando na ideia de regra matriz de incidência. ${ }^{71}$

Para Paulo de Barros Carvalho, as normas tributárias podem ser classificadas de acordo com a sua finalidade enquanto normas funcionais (definidoras de princípios), normas de incidência (demarcadoras dos elementos da relação tributária obrigacional) e normas operativas (que fixam providências administrativas e instrumentais). ${ }^{72}$

As três categorias podem ser consideradas normas tributárias em sentido amplo, mas apenas as normas de incidência possuem regras especialíssimas que demarcam o

${ }^{68}$ Idem.

${ }^{69}$ Ibidem, p. 41.

${ }^{70}$ Ibidem, p. 39

${ }^{71}$ CALIENDO, Paulo, op. cit., pp. 86 e 87.

${ }^{72}$ CARVALHO, Paulo de Barros. Curso de Direito Tributário. $23^{\text {a }}$ Ed. São Paulo: Saraiva, 2011, p. 293. 
núcleo do tributo, a chamada regra-matriz de incidência, que podem ser designadas por normas tributárias em sentido estrito. ${ }^{73}$

A regra-matriz de incidência, no entanto, não corresponde a uma norma tributária específica, mas a um construto teórico que pode ser realizado para cada tributo. ${ }^{74}$ Tratase de buscar extrair, hermeneuticamente, das normas tributárias, os elementos nucleares da incidência tributária, como dispostos no organograma abaixo:

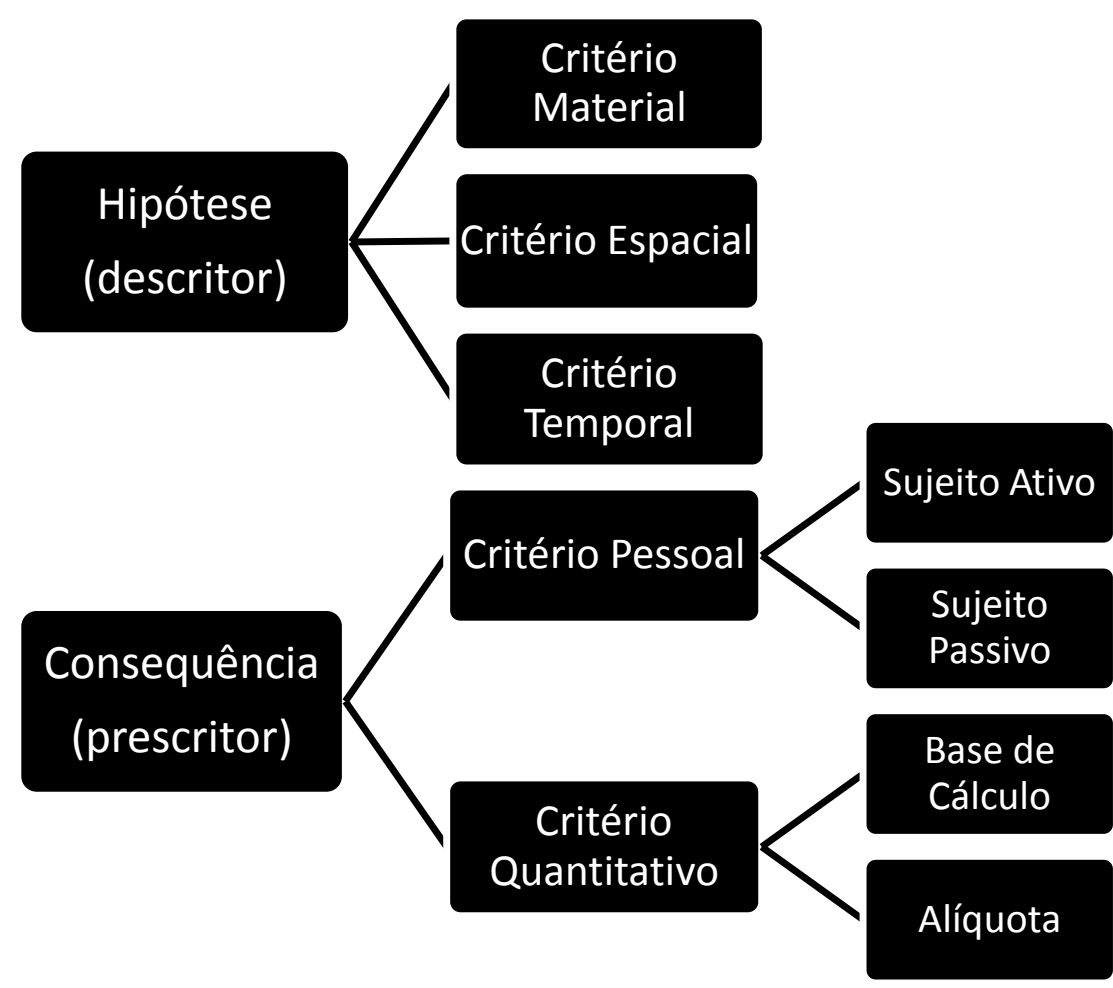

Vide: CARVALHO, Paulo de Barros. Curso de Direito Tributário, pg. 295

Identificar e preencher os fatores da regra-matriz de incidência torna-se o objetivo da doutrina do direito tributário, como se nota na própria explicação de Paulo de Barros:

Redizemos que as leis não trazem normas jurídicas organicamente agregadas, de tal modo que nos seja lícito desenhar, com facilidade, a indigitada regra-matriz de incidência, que todo o tributo hospeda, como centro catalisador de seu plexo normativo. Pelo contrário, sem arranjo algum, os preceitos se dispersam pelo corpo do estatuto, compelindo o jurista a um penoso trabalho de composição.

${ }^{73}$ Ibidem, p. 294.

${ }^{74}$ Idem. 
Visto por esse prisma, o labor científico aparece como árduo esforço de procura, isolamento de dados, montagem e construção final do arquétipo da norma jurídica. ${ }^{75}$

Diante desse quadro teórico, percebemos que a doutrina brasileira do direito tributário migrou, progressivamente, da crítica à presença de elementos econômicos, políticos e sociais na compreensão jurídica dos tributos, para a formatação de uma regra abstrata de análise subsumível a qualquer tributo.

\begin{abstract}
A figura jurídica do tributo tem merecido alentada e profunda atenção da doutrina especializada. (...) Cumpre distinguir duas espécies de conceitos: a) aqueles que foram construídos com o auxílio de categorias e raciocínios da Economia e da Ciência das Finanças, contra os quais se insurgiram, entre outros, Giannini e Berlini, na Itália, e Sainz de Bujanda, na Espanha, e que sofreram as críticas veementes de Becker e Geraldo Ataliba, no Brasil; b) aqueles outros que os sucederam (...)

Os primeiros, mutilados por críticas certeiras, totalmente esbatidos, são hoje apenas imagem pálida de uma época obscura e sem inspiração da ciência do direito tributário, de modo que se faz despiciendo reconsiderá-los. Os últimos, porém, engendrados por uma doutrina mais consciente e esclarecida (...) estão em pleno vigor, recebendo a cada passo as loas incondicionais de reputados cientistas. $^{76}$
\end{abstract}

Em paralelo a esse movimento, o objeto de análise do direito tributário foi também migrando do tributo e das normas jurídicas, que têm por conteúdo a tributação, para a relação jurídica obrigacional, entre sujeito ativo e sujeito passivo, derivada das normas jurídicas.

Paulo de Barros Carvalho, em prefácio escrito à $4^{\mathrm{a}}$ edição da Teoria Geral do Direito Tributário de Alfredo Augusto Becker, argumenta que de todos os atributos que possam ser conferidos à sua obra, um em especial é suficiente para comprovar seu caráter inestimável: o de ter feito escola, de haver influenciado gerações. ${ }^{77}$

Influência essa que pode ser observada na própria obra de Paulo de Barros Carvalho:

\footnotetext{
${ }^{75}$ Ibidem, p. 296.

${ }^{76}$ CARVALHO, Paulo de Barros. Teoria da Norma Tributária, Max Limonad, $3^{\text {a }}$ ed. São Paulo, 1998, pp. 86 e 87.

${ }^{77}$ BECKER, Alfredo Augusto, op. cit., prefácio.
} 
Em princípio, cumpriria a todos os autores que, deliberadamente ou não, cuidam de fazer ciência do Direito Tributário, debruçar-se sobre esse processo de reflexão, numa tentativa estrênue de apurar o método dessa matéria científica. (...) Se a forma com que enfocamos a norma jurídica tributária vier a demonstrar a preocupação com o método, a necessidade ingente de desatarmos os incontornáveis problemas desse campo jurídico com instrumentos tomados na sede da Teoria Geral do Direito, de certo que haveremos de ter atingido os nossos objetivos.",78

Fato é que, independentemente do papel da obra de Alfredo Augusto Becker na constituição de toda uma inspiração doutrinaria tributária brasileira, fortemente marcada pelo resgate de uma matriz kelseniana de análise, não resta dúvida de que a mesma prosperou e se consolidou até os dias de hoje. Uma tradição voltada para a teoria da norma tributária em seus aspectos semânticos, sintáticos e pragmáticos. ${ }^{79}$

Seria equivocado assumir que tal caminho fora fruto tão somente de uma opção doutrinária ou de uma predileção metodológica. As causas deste processo são diversas e dificilmente poderiam ser esgotadas neste espaço. ${ }^{80}$

Entretanto, partilhamos do diagnóstico de José Maria Arruda de Andrade, quando ele diz que as teorias de interpretação funcionalista e econômica não consolidaram muitos elementos à hermenêutica tributária brasileira, sendo muito mais significativos para sua compreensão os legados das escolas formalistas. ${ }^{81}$ Fato tal que o próprio magistério de Ricardo Lobo Torres também reconhece. Em seu esforço por propagar uma corrente de interpretação valorativa, o autor revela que os ranços de uma crença na capacidade de fechamento dos conceitos jurídicos seguem sendo o norte da majoritária produção literário-tributária brasileira ainda hoje. ${ }^{82}$

(...) a influência dos brilhantes tributaristas italianos das décadas de 30 e 40 sobre a geração contemporânea à elaboração do Código Tributário Nacional teve extraordinária importância para o desenvolvimento do direito tributário brasileiro, que não seria, hoje, melhor se recepcionados outros modelos estrangeiros. A insistência, todavia, no século XXI, em repetir as velhas ideias italianas daquela fase representa atraso considerável, posto que se torna

${ }^{78}$ CARVALHO, Paulo de Barros. Teoria da Norma Tributária, Max Limonad, $3^{\mathrm{a}}$ ed. São Paulo, 1998, p. 115.

${ }^{79}$ CALIENDO, Paulo, op. cit., p. 87.

${ }^{80}$ José Maria Arruda de Andrade, por exemplo, destaca que, no Brasil, o estudo da relação tributária tendo a relação obrigacional do direito civil como modelo sempre teve muito eco. Em parte, reputa o autor, pela forte influência liberal decorrente do formalismo italiano que logrou conquistar muitos adeptos no Brasil e, em parte, pelo próprio engajamento profissional de boa parte dos doutrinadores. In: ANDRADE, José Maria Arruda de. Interpretação da Norma Tributária. 1. Ed. São Paulo: MP Editora, 2006. v. 1. p. 78.

${ }^{81}$ Ibidem, p. 103.

${ }^{82}$ Ibidem, p. 96. 
necessário o estudo do direito tributário sob a perspectiva dos direitos humanos e da justiça, orientação que os atuais juristas italianos vêm adotando, com pouca repercussão no Brasil. ${ }^{83}$

Tendo esse panorama da história das ideias do direito tributário como pano de fundo, podemos perceber, sobretudo no caso brasileiro, que - independentemente das causas que conduziram a esse quadro - o desenvolvimento histórico da dogmática jurídica do direito tributário se deu sob forte inspiração de uma matriz kelseniana. Caminhou no sentido da teoria geral, da pureza do direito e da análise da sua forma em detrimento de seu conteúdo e sua especificidade. ${ }^{84}$

Ainda que se admita o quadro de Ricardo Lobo Torres, de uma tendência progressiva rumo a uma doutrina valorativa do direito tributário no Brasil, a teoria da norma jurídico-tributária segue sendo o ponto de partida hermenêutico para a sua compreensão.

É importante esclarecer que por matriz kelseniana de análise não objetivamos fazer um juízo de valor, mas, por meio de uma metáfora, apontar um movimento orientador da dogmática tributária no sentido do formalismo, da constituição de uma doutrina positivista sobre o direito tributário, de exclusão dos elementos políticos, econômicos e sociais do foco de análise da disciplina.

Essa constatação nos interessa, também, porque tal caminho é justamente o inverso do trilhado pelo desenvolvimento da doutrina e da dogmática jurídica do direito econômico brasileiro.

${ }^{83}$ TORRES, Ricardo Lobo. As influências italianas no direito tributário brasileiro. In: Revista de Direito Tributário, v. 84, São Paulo, Malheiros, 2002, p. 80.

84، Importa acentuar que as diversas propostas cognoscentes do direito positivo (História do Direito, Sociologia Jurídica, Antropologia Cultural do Direito, Dogmática Jurídica etc.) têm, todas elas, a mesma dignidade científica, descabendo privilegiar uma, em detrimento das demais. Mas há um ponto que não deve ser esquecido: a cada uma das ciências jurídicas corresponde um método de investigação, com suas técnicas especiais de focalizar o objeto. (...) Quanto à dogmática, ou Ciência do Direito stricto sensu, que se ocupa de descrever o direito positivo tal como ele se apresenta, (...) Vale para Ciência do Direito, exclusivamente, a ordem jurídica posta, isto é, o direito positivo considerado hic et nunc.” In: CARVALHO, Paulo de Barros. op. cit. 2011, p. 45. 


\title{
1.2 - A Doutrina do Direito Econômico
}

O reconhecimento da necessidade do pensamento jurídico se debruçar sobre o conjunto de técnicas - de direito público e privado - utilizadas pelo Estado para conformar uma dada economia, só foi possível após um longo período de resistência da academia tradicional de direito. ${ }^{85}$ A função econômica das normas jurídicas não era encarada como uma questão pertinente à ciência do direito, a qual caberia refletir somente sobre o conteúdo e o significado das mesmas.

Gilberto Bercovici lembra que a teoria jurídica europeia do final do século XIX é estatalista e liberal, inspirada na transposição do método jurídico de Savigny e da Pandectística do direito privado para o direito público. ${ }^{86}$ Segundo Alberto Venâncio Filho, o direito econômico surge, especialmente, em face da incapacidade da dogmática jurídica tradicional lidar com as progressivas alterações e aperfeiçoamentos das técnicas jurídicas de intervenção do Estado na economia. ${ }^{87}$

Todavia, na medida em que se intensificavam a presença e o controle do Estado sobre o funcionamento do mercado, sobretudo com o esforço de guerra, ${ }^{88}$ vislumbravase a complexificação da regulação jurídica da economia, por meio da positivação de princípios teleológicos, direcionadores de fins e objetivos econômicos, e regras jurídicas de competência, disciplinadoras e organizadoras do exercício destas funções estatais.

\begin{abstract}
A partir do século XX, portanto, as constituições passam a conter normas atribuidoras de competência para elaboração e a implementação da política econômica e estabelecem o fundamento jurídico para que os Estados tomem as medidas econômicas necessárias. A efetividade da política econômica torna-se, assim, também uma tarefa do direito. ${ }^{89}$
\end{abstract}

\footnotetext{
${ }^{85}$ “O jurista, acostumado às velhas técnicas do Direito Público, distribuído entre as rubricas da organização dos Poderes do Estado, a das relações entre este e os indivíduos e entidades jurídicas, à delimitação dos campos clássicos de atuação estatal, recebe com maiores preconceitos as inovações. Estas, formuladas sob a pressão de necessidades instantes, não se revestem sempre de forma de pureza e nitidez jurídica. Cria-se, assim, uma atitude preconceitual do jurista a esse novo atuar do Estado, e ele, ao invés de colaborar no aperfeiçoamento das fórmulas, concorre, não raro, para a perda de nitidez e substância das soluções propostas.” In: VENÂNCIO FILHO, Alberto. A intervenção do Estado no domínio econômico: o Direito público econômico no Brasil. Rio de Janeiro: Renovar, 1998, p. 73.

${ }^{86}$ BERCOVICI, Gilberto. op. cit. 2009, pp. 506 e 507.

${ }^{87}$ VENÂNCIO FILHO, Alberto. op. cit, p. 69.

${ }^{88}$ Para uma visão mais aprofundada deste período ver: BERCOVICI, Gilberto. op. cit. 2009, pp. 508-512.

${ }^{89}$ BERCOVICI, Gilberto. op. cit. 2012, p. 208
} 
Em um primeiro momento, a denominação direito econômico é justamente uma decorrência natural da assimilação desse processo por uma doutrina enraizada na cultura do liberalismo econômico. Considerava-se econômico esse direito público e cogente que surgia com a função social da propriedade, a disciplina do crédito, a organização de mercados e a regulação da concorrência, principalmente porque se considerava que todo o "outro" direito não era econômico. ${ }^{90}$

No Estado Liberal não haveria regulação jurídica da atividade econômica, existindo, quando muito, regras dispositivas que não se sobrepunham à liberdade contratual, ao direito civil e comercial. ${ }^{91}$

De toda sorte, o despertar tardio do pensamento jurídico para a reflexão sobre o papel desempenhado pelo Estado na economia não altera o fato de que ele sempre o tenha exercido, ainda que de diferentes formas. ${ }^{92}$

A esse respeito é elucidativo que a sociologia jurídica de Max Weber já se voltasse, no século XIX, para a relação entre o ordenamento jurídico e a economia, seus efeitos e implicações, e apontasse a centralidade de um direito racional para o funcionamento do capitalismo liberal, ${ }^{93}$ bem como a presença de institutos jurídicos pressupostos no próprio tipo ideal de um mercado autorregulado, como o direito de propriedade privada e o contrato. ${ }^{94}$

\footnotetext{
${ }^{90}$ COMPARATO, Fabio Konder. op. cit., pp. 16 e 17.

${ }^{91}$ VIDIGAL, Geraldo de Camargo. Teoria Geral do Direito Econômico. São Paulo: Revista dos Tribunais, 1977, p. 24

${ }^{92}$ BERCOVICI, Gilberto. Constituição econômica e desenvolvimento - Uma leitura a partir da constituição de 1988. São Paulo: Malheiros, 2005, p. 32

93،“(...) para os interessados no mercado de bens, a racionalização e a sistematização do direito significaram, em termos gerais e com a reserva de uma limitação posterior, a calculabilidade crescente do funcionamento da justiça - uma das condições prévias mais importantes para empresas econômicas permanentes, especialmente aquelas de tipo capitalista, que precisam de "segurança de tráfico" jurídica." In: WEBER, Max. Economia e Sociedade. Trad. Regis Barbosa e Karen Barbosa. Vol. 2. Brasília: Editora UNB, 1999, p. 144.

94“'De forma conceitual o Estado não é indispensável a qualquer atividade econômica. Todavia, um sistema econômico, especialmente o moderno, poderia certamente não existir sem uma ordem jurídica com características especiais; características essas que poderiam apenas ser desenvolvidas tendo como referência uma ordem jurídica "estatuída". A vida econômica atual depende inteiramente das oportunidades adquiridas por meio de contratos. Ainda são consideráveis os interesses privados nas obrigações contratuais e o interesse comum de todos os detentores de bens na proteção mútua de seus bens." In: WEBER, Max. O Direito na Economia e na Sociedade. Trad. Marsely De Marco Martins Dantas. 1 ${ }^{\text {a }}$ Ed. São Paulo: Ícone, 2011, pp. 53 e 54.
} 
Em um segundo momento, a inadequação da terminologia econômico abriu caminho para uma tentativa de classificar esse novo direito por meio de uma detalhada rede de novos ramos.

Geraldo Camargo Vidigal propôs separá-lo entre o Direito do Planejamento, o Direito Administrativo Econômico e o Direito da Administração dos Mercados. ${ }^{95}$ Alberto Venâncio Filho, sugeriu a nomenclatura de Direito Público Econômico, subdividido em Direito Regulamentar e Direito Institucional. ${ }^{96}$

Embora tenham aberto importantes flancos no esclarecimento das áreas de atuação do Estado sobre o espaço econômico, tais tentativas não lograram abarcar toda complexidade desse campo. Isso porque, mais do que um ramo, os desafios da nova ordem econômica do pós-guerra impunham uma nova compreensão metodológica da análise do direito, particularmente para abordar as políticas públicas do Estado, principalmente suas políticas econômicas.

A análise jurídica das políticas públicas, no entanto, sempre se apresentou como um grande desafio. Elas não se constituem como uma categoria definida pelo direito, mas como arranjos complexos de atividades governamentais. ${ }^{97}$

Políticas Públicas são programas de ação governamental visando coordenar os meios à disposição do Estado e as atividades privadas, para a realização de objetivos socialmente relevantes e politicamente determinados. ${ }^{98}$

Maria Paula Bucci Dallari afirma que embora não haja um conceito jurídico de políticas públicas, deve haver uma metodologia jurídica para abordá-las, ${ }^{99}$ pois incumbe aos juristas descrevê-las, compreendê-las e analisá-las de modo a conceber as formas e processos jurídicos a elas correspondentes. ${ }^{100}$ Uma abordagem que necessariamente ensejará a combinação de elementos multidisciplinares, capazes de apreender a forma, o conteúdo e as finalidades das políticas públicas na economia.

\footnotetext{
${ }^{95}$ VIDIGAL, Geraldo de Camargo. op. cit., p. 33.

${ }^{96}$ VENÂNCIO FILHO, Alberto. op. cit, p. 77.

97 DALlARI BUCCI, Maria Paula. O Conceito de Política Pública em Direito. In: DALLARI BUCCI, Maria Paula (org.). Políticas Públicas: Reflexões sobre o Conceito Jurídico. São Paulo: Saraiva, 2006, p. 31.

${ }^{98}$ Ibidem, p. 38.

${ }^{99}$ Ibidem, p. 47

${ }^{100}$ Idem.
} 
Na mesma linha de raciocínio, Fábio Konder Comparato alerta para o fato de que a análise jurídica das políticas públicas, enquanto arranjos complexos que são, há que se voltar tanto para a adequação de seus fins quanto dos seus meios. Ser capaz de olhar a parte e o todo.

\begin{abstract}
A primeira distinção a ser feita, no que diz respeito à política como programa de ação, é de ordem negativa. Ela não é uma norma, ou seja, ela se distingue nitidamente dos elementos da realidade jurídica, sobre os quais os juristas desenvolveram a maior parte de suas reflexões, desde os primórdios da iurisprudentia romana. (...)

Mas se a política deve ser claramente distinguida das normas e dos atos, é preciso reconhecer que ela acaba por englobá-los como seus componentes. É que a política aparece, antes de tudo, como uma atividade, isto é, um conjunto organizado de normas e atos tendentes à realização de um objetivo determinado. (...)

A política como conjunto de normas e atos, é unificada pela sua finalidade. Os atos, decisões ou normas que a compõem, tomados isoladamente, são de natureza heterogênea e submetem-se a um regime jurídico que lhes é próprio.

De onde se segue que o juízo de validade de uma política - seja ela empresarial ou governamental - não se confunde nunca com o juízo de validade das normas e dos atos que a compõem. Uma lei editada no quadro de determinada política pública, por exemplo, pode ser inconstitucional sem que esta última o seja. Inversamente, determinada política governamental, em razão da finalidade por ela perseguida, pode ser julgada incompatível com os objetivos constitucionais que vinculam a ação do Estado sem que nenhum dos atos administrativos, ou nenhuma das normas que a regem, sejam, em si mesmos, inconstitucionais. ${ }^{101}$
\end{abstract}

A aplicação da função econômica das normas jurídicas e da estrutura jurídica da economia não poderia ser feita a contento por meio de uma metodologia caracterizada pelo estudo descritivo e classificatório do conteúdo formal das normas jurídicas. ${ }^{102}$ Haja vista o que foi primeiramente destacado por Norbert Reich como uma das características preponderantes do direito econômico: sua dupla instrumentalidade. ${ }^{103} \mathrm{Se}$ de um lado ele permite a organização da economia de mercado pelo Estado, também permite que o Estado a manipule e transforme em busca de determinadas finalidades políticas. $^{104}$

${ }^{101}$ COMPARATO, Fabio Konder. Ensaio sobre o juízo de constitucionalidade de políticas públicas. In: BANDEIRA DE MELLO, Celso Antônio. Estudo em Homenagem a Geraldo Ataliba. São Paulo: Malheiros, 1997 , v. 2, pp. 353 e 354.

${ }^{102}$ COMPARATO, Fabio Konder. op. cit. 1965, p. 25. Ver também: SOUZA, Washington Peluso Albino de. Direito Econômico. São Paulo: Saraiva, 1980, p. 54

${ }^{103}$ REICH, Norbert. Markt und Recht: Theorie und Praxis des Wirtschaftsrecht in der Bundesrepublik Deutschland, Neuwied/Darmstadt, Luchterhand, 1977, pp. 29-64. Apud: BERCOVICI, Gilberto. op. cit. 2009, p. 504.

${ }^{104}$ Idem. 
A organização do processo econômico, necessariamente, encerra um conflito político, e a compreensão acerca do direito que instrumentaliza essa organização não poderia ignorar essa dimensão.

Assim, fica clara a importância de uma cultura jurídica reformulada, receptiva a um maior sincretismo analítico que abriria caminho para a ideia de um direito econômico, entendido também enquanto um método de compreensão e interpretação do direito, ${ }^{105}$ voltado para a análise substancial e crítica da utilidade funcional de todo o direito positivo. $^{106}$

Por essas razões que na doutrina brasileira do direito econômico esse sincretismo prosperou, justamente, por meio de uma demarcação funcional do campo e do objeto de estudo. A definição de Washington Peluso Albino de Souza é elucidativa disso. Em suas palavras, o direito econômico é:

(...) o ramo do direito composto por um conjunto de normas de conteúdo econômico que objetivam regulamentar a política econômica harmonizando os interesses individuais e coletivos, harmonizando-as - pelo princípio da "economicidade" - com a ideologia adotada na ordem jurídica. ${ }^{107}$

Nota-se, portanto, que para o clássico autor o conteúdo econômico não é causa suficiente para classificar a norma como objeto de estudo do direito econômico, devendo haver nela o objetivo de regulamentar uma política econômica. Dessa maneira, a finalidade social da norma, dos efeitos decorrentes de sua eficácia, passa a ser definidora da classificação enquanto objeto de estudo do direito econômico.

A consequência disso é que a natureza econômica de uma norma, ou o princípio da economicidade, ${ }^{108}$ se caracterizaria não pelo seu conteúdo, mas pela sua finalidade. $\mathrm{O}$ direito econômico seria, por definição, um direito funcional.

Dessa feita, não apenas normas deliberadamente voltadas para o regramento da economia são dotadas de economicidade (que coloca em prática medidas de política econômica), ${ }^{109}$ já que normas de outros ramos como o direito civil, o direito comercial,

\footnotetext{
${ }^{105}$ GRAU, Eros Roberto. A ordem econômica na constituição de 1988: Interpretação e Crítica. $8^{\text {a }}$ ed.São Paulo: Malheiros, 2003, p.152.

${ }^{106}$ Ibidem, p. 153.

${ }^{107}$ SOUZA, Washington Peluso Albino de. op. cit., p. 3. Ver também: GRAU, Eros Roberto. op. cit., p. 154.

${ }^{108}$ SOUZA, Washington Peluso Albino de. op. cit., p. 32.

${ }^{109}$ Idem.
} 
o direito administrativo, o direito penal e o direito constitucional também podem ser instrumentos para a realização da política econômica do Estado.

De tal maneira que o estudo do conteúdo econômico e da política econômica presente nas normas jurídicas pode-se estender a praticamente qualquer ramo do direito. Vai ao encontro desse quadro, por exemplo, a posição do tributarista Klaus Tipke, para quem as normas tributárias com finalidade social, que procuram direcionar o comportamento econômico ou a estrutura social, não pertencem ao direito tributário, mas, sim, ao direito econômico. ${ }^{110}$

Nesse sentido, as lições de Eros Grau demarcam com precisão para doutrina brasileira que o direito econômico, muito além de um "novo" ramo específico do direito, previsto nos artigos 24, 173 e 174 da constituição de 1988, atinente à regulação e à "intervenção" do Estado sobre a atividade econômica - que "outrora" fora exercida sem restrições pela liberdade de iniciativa privada - se constitui também como um método de compreensão de todos os ramos do direito quando exercidos em busca de determinados fins econômicos. ${ }^{111}$ Um método de análise da atuação do Estado, por meio do direito, sobre o espaço econômico (por indução ou direção) e no espaço econômico (por absorção ou participação). ${ }^{112} \mathrm{O}$ direito econômico, portanto, enquanto disciplina, estuda o papel do Estado na organização da estrutura do modo de produção econômica. É o direito das políticas econômicas. ${ }^{113}$

Gilberto Bercovici lembra que o estudo da política econômica também pode ser definido como o estudo das formas e efeitos da intervenção do Estado na vida econômica, visando a atingir determinados fins. ${ }^{114}$ As origens da política econômica remontam justamente ao processo de nacionalização da moeda, das finanças e do crédito e a criação de um sistema tributário nacional. ${ }^{115}$ Razão pela qual autores como Reiner Schmidt procuraram defini-la, em termos jurídicos, enquanto o conjunto de medidas soberanas por meio das quais se determinam as condições que estão

\footnotetext{
${ }^{110}$ Vide: SHOUERI, Luís Eduardo. Normas Tributárias Indutoras e Intervenção Econômica. Rio de Janeiro: Forense, 2005, p. 228.

${ }^{111}$ GRAU, Eros Roberto. op. cit., p.152.

112 Ibidem, p. 148.

${ }^{113}$ COMPARATO, Fábio Konder. op. cit. 1965, p. 22.

114 Ainda que para o autor essa definição esteja embebida por uma visão neoclássica da teoria econômica. Vide: BERCOVICI, Gilberto. op. cit. 2012, p. 200.

${ }^{115}$ Ibidem, p. 201.
} 
submetidas as atividades econômicas privadas e se determinam fins a serem alcançados. $^{116}$

Cada período histórico possui sua própria consciência das estreitas relações entre direito e economia. ${ }^{117}$ Nesse sentido, a historicidade é marca não apenas do direito econômico, mas também do conhecimento sobre ele. Principalmente, na medida em que ele se caracteriza por ser um direito dinâmico, fundado na mediação pelo Estado da liberdade individual e do conflito coletivo no processo econômico, que pode se afigurar de diferentes formas. ${ }^{118}$

Em verdade, essa compreensão funcional do direito positivo reúne uma razoável variedade de métodos e abordagens possíveis e está longe de constituir um campo consolidado teoricamente e ausente de disputas.

A despeito das muitas polêmicas e definições que ainda concorrem o debate sobre os limites e conceitos comuns desta disciplina, os trabalhos, a doutrina e a dogmática do direito econômico, nos dizeres de Fábio Konder Comparato, se desenvolveram da análise do conteúdo, da finalidade e dos traços específicos das normas de direito econômico.

Pode-se dizer hoje em dia que fugindo não só ao esplêndido idealismo das doutrinas puras do direito, como ao desprêzo sistemático pelas categorias jurídicas formais manifestado pelos práticos, a cultura jurídica tende a encaminhar-se no sentido de uma compreensão global do mundo do Direito: não só o estudo das relações jurídicas segundo o aspecto formal, mas também a análise de sua evolução histórica e utilidade funcional. ${ }^{119}$

De tal maneira que a dogmática jurídica do direito econômico brasileiro caminhou no sentido da "impureza" do direito, em detrimento de uma investigação exclusivamente lógico-formal sobre a interpretação dessas normas, ${ }^{120}$ enquanto

\footnotetext{
${ }^{116}$ Ibidem, p. 209.

${ }^{117}$ BERCOVICI, Gilberto. op. cit. 2009, p. 504.

${ }^{118}$ Ibidem, p. 515.

${ }^{119}$ COMPARATO, Fabio Konder. op. cit. 1965, p. 25.

${ }^{120}$ Nas palavras de Fábio Konder Comparato: "Até agora a doutrina jurídica tem-se preocupado quase que exclusivamente com o direito formal (...). Não seria tempo de se admitir modestamente o que outras ciências sociais já admitiram desde a primeira hora: que ao lado de uma análise de conceitos e de categorias, existe um estudo de técnicas? Que ao lado de um direito formal deve haver lugar para um direito aplicado? O direito econômico aparece assim como um dos ramos dêste direito aplicado (...)." In: COMPARATO, Fabio Konder. op. cit. 1965, p. 25.
} 
análises dos aspectos jurídicos da estrutura do modo de produção econômica. ${ }^{121}$ Uma ciência social aplicada, ${ }^{122}$ o conjunto de técnicas jurídicas de que lança mão o Estado na execução de sua política econômica. ${ }^{123}$

${ }^{121}$ AGUILLAR, Fernando Herren. Direito Econômico: Do Direito Nacional ao Direito Supranacional. $2^{\text {a }}$ ed. São Paulo: Atlas, 2009, p. 30.

${ }_{122}$ COMPARATO, Fabio Konder. op. cit. 1965, p. 21.

${ }^{123}$ Ibidem, p. 22. 


\section{3 - A Dimensão Extrafiscal da Tributação.}

\subsection{1. - O Conceito de Extrafiscalidade na Doutrina Tributária}

Aliomar Baleeiro, em seu Manual de Introdução à Ciência das Finanças, assevera que a doutrina norte-americana, inspirada pelas decisões de seus tribunais, construíra uma distinção quanto à fundamentação dos tributos. Poderiam eles ser exigidos com base no poder de tributar do Estado, ou com base em seu poder de polícia (under the police power) ${ }^{124}$ No primeiro caso, tratar-se-ia de tributos com finalidades puramente fiscais, enquanto no segundo de tributos com finalidades extrafiscais ou regulatórias. ${ }^{125}$

Seguindo a mesma trilha, Ruy Barbosa Nogueira definiu a extrafiscalidade como a intervenção estatal por meio da tributação, de forma a estimular ou desestimular condutas. ${ }^{126}$ Misabel Derzi caracterizou a tributação que não tende, prioritariamente, prover o Estado de meios para seu custeio, mas ordenar a propriedade de acordo com a sua função social ou intervir em dados conjunturais e estruturais da economia. ${ }^{127}$

Abordando o conceito, não enquanto uma característica da tributação, mas de sua utilização, Geraldo Ataliba classificou a extrafiscalidade como o emprego deliberado, não apenas de tributos, mas de instrumentos tributários para finalidades regulatórias de comportamentos sociais, em matéria econômica, social e política. ${ }^{128}$ No mesmo sentido, Paulo de Barros Carvalho chama de extrafiscal a forma de manejar elementos jurídicos usados na configuração dos tributos, perseguindo objetivos e metas outros à arrecadação. ${ }^{129}$

Sintetizando o debate à sua época, a despeito de eventuais imprecisões, ${ }^{130}$ fica o entendimento de Walter Barbosa Corrêa, para quem:

\footnotetext{
124 Muito embora o autor aponte a crítica recebida pela distinção. Vide: BALEEIRO, Aliomar. Uma Introdução à Ciência das Finanças. 14 ${ }^{\mathrm{a}}$ ed. Rio de Janeiro: Forense, 1984, p. 176.

${ }^{125}$ BALEEIRO, Aliomar. op. cit. 1984, p. 177.

${ }^{126}$ NOGUEIRA, Ruy Barbosa. Curso de Direito Tributário. São Paulo: Saraiva, 1986, p. 197.

${ }^{127}$ BALEEIRO, Aliomar. Direito Tributário Brasileiro. Rio de Janeiro: Forense, 1970, pp. 233 e 234.

${ }^{128}$ ATALIBA, Geraldo. Apontamentos de Ciência das Finanças: Direito Financeiro e Tributário. $2^{\mathrm{a}}$ Ed. São Paulo: Revista dos Tribunais, 1969, p. 137.

${ }^{129}$ CARVALHO, Paulo de Barros. op. cit. 2011, pp. 287 e 288.

${ }^{130}$ Como a restrição do fenômeno as leis, sendo que hoje é bastante claro que a extrafiscalidade se dá por meio de diversas espécies normativas, muitas delas infra-legais.
} 
Extrafiscalidade é o fenômeno manifestado em algumas leis relativas à entrada derivada, que lhes confere características de consciente estímulo ao comportamento das pessoas e de não ter por fundamento precípuo arrecadar recursos pecuniários a ente público. ${ }^{131}$

Muito embora a utilização do instrumento tributário com finalidades outras, que não a financeira, possa ser encontrada desde a antiguidade, não há dúvida de que o contexto da revolução teórica keynesiana contribuiu para aclarar esse fato ao multiplicar os exemplos de aplicações extrafiscais da tributação. Foi a partir da década de 1930 que sua aplicação consciente ganhou volume e intensidade, demonstrando que os mesmos não constituíam um fenômeno excepcional, mas uma nova tendência que imperaria sob a construção do direito tributário. ${ }^{132}$

É no debate acerca da extrafiscalidade em que o direito tributário registra os impactos sofridos pela tributação em face das transformações do padrão normativo do Estado Liberal ao Estado Social ao longo do século XX.

Não passou despercebido o forte abalo sofrido pela doutrina do período do Estado Liberal diante dessas mudanças. Alberto Deodato remonta com riqueza de detalhes os primórdios do debate acerca da existência de funções extrafiscais nos impostos ou da neutralidade inerente à tributação. ${ }^{133}$ Num primeiro momento, não houve apenas quem se opusesse às mesmas, como muitos chegaram a negar a sua efetividade ${ }^{134}$ e sua juridicidade. ${ }^{135}$

Assim também, Walter Barbosa Corrêa apontou mudanças sofridas pela doutrina por efeito dos estudos da extrafiscalidade. Segundo ele, por exemplo, a definição de tributo deixou de apegar-se a ideia de destinação do produto à cobertura dos fins

${ }^{131}$ CORRÊA, Walter Barbosa. Contribuição ao Estudo da Extrafiscalidade. São Paulo: Faculdade de Direito da USP. Tese de Livre Docência, 1964, p. 54.

${ }^{132}$ BECKER, Alfredo Augusto, op. cit., pp. 622 e 623.

${ }^{133}$ Nesse sentido, conclui: “O pensamento de que o impôsto tem funções econômicas, sociais e políticas, data da criação dos primeiros tributos. Nunca houve tributo neutro. Se êsse pensamento teve opositores, deve-se aos escritores do liberalismo antigo que defendiam a própria neutralidade do Estado diante da vida social. (...) Todos os impostos têm função social, econômica e política, porque os próprios impostos chamados de pura fiscalidade são transferidores de riquezas de uma para outra classe ou criadores de novas fontes de produção para o bem-estar social.” In: DEODATO, Alberto. As Funções Extra-Fiscais do Imposto. Belo Horizonte: Faculdade de Direito da Minas Gerais. Tese para o Concurso de Professor Catedrático de Ciência das Finanças, 1949, pp. 147 e 148.

${ }^{134}$ Nesse sentido, segundo Alberto Deodato, argumentava o economista francês Henry Laufenburger: "O verdadeiro motor do intervencionismo econômico e social é, sem dúvida, a despesa pública, ato político por definição. (...) o impôsto, na medida em que revela uma intenção extra-fiscal, é nitidamente inferior à despesa pública.” In: Ibidem, pp. 50 e 51.

${ }^{135}$ A esse respeito ver: ATALIBA, Geraldo, Sistema Constitucional Tributário Brasileiro. Ed. Revista dos Tribunais, 1968, p. 152. 
estabelecidos pelo Estado; ${ }^{136}$ a noção de evasão fiscal foi apurada, distinguindo-se a fraude fiscal da evasão lícita ${ }^{137}$ e a própria noção de que a atividade financeira não se limitava a ser instrumental, mas de que era também política e cumpria diretamente os objetivos e funções do Estado, foram legados da extrafiscalidade para a dogmática tributária. $^{138}$

A abordagem da extrafiscalidade pelo direito tributário sempre foi tema controverso. Sobretudo, porque a finalidade da tributação não é intrínseca aos institutos tributários, mas depende sempre do contexto em que é lançada. Comumente temos exemplos de utilização de tributos com vocação regulatória para aumentar ou equilibrar as receitas do Estado, assim como de utilização de tributos com vocação arrecadatória como forma de coibir condutas e regular comportamentos.

Em casos concretos, as pretensões fiscais e extrafiscais da tributação raramente se manifestam isoladamente em determinados tributos, ou institutos tributários. A esse respeito, nos parece pertinente a advertência de Marcus de Freitas Gouvêa, de que fiscalidade e extrafiscalidade separam-se apenas hipoteticamente para fins didáticos. ${ }^{139}$ Como lembra Alberto Deodato: "Todos os impostos exercem função social, econômica e política. Uns, conforme afirmamos, a exercem imediatamente, outros, mediatamente, e outros das duas maneiras. "140

Provém daí a afirmação de Alfredo Augusto Becker de que o finalismo fiscal e extrafiscal coexistem nos institutos do direito tributário como faces de uma mesma moeda, ${ }^{141}$ na medida em que a política fiscal implementada os instrumentaliza em um sentido ou em outro. ${ }^{142}$ Para Ricardo Lobo Torres, a extrafiscalidade como forma de intervenção estatal na economia, se deixa absorver pela fiscalidade por um lado e por outro permanece como categoria autônoma de ingressos públicos. ${ }^{143}$

Luís Eduardo Schoueri observa que o enfoque mais apropriado para a questão seria uma análise pragmática do efeito das normas tributárias - no plano da eficácia - ao invés da tentativa de identificação da finalidade arrecadatória, indutora, distributiva

\footnotetext{
${ }^{136}$ CORRÊA, Walter Barbosa. op. cit., p. 73.

${ }^{137}$ Ibidem, p. 74

${ }^{138}$ Ibidem, p. 76.

${ }^{139}$ GOUVÊA, Marcus de Freitas. A Extrafiscalidade no Direito Tributário. Belo Horizonte: Del Rey, 2006, p. 47.

${ }_{140}$ DEODATO, Alberto. op. cit. 1949, p. 67.

${ }^{141}$ BECKER, Alfredo Augusto, op. cit. 1989, p. 633.

${ }^{142}$ Ibidem, p. 632.

${ }^{143}$ TORRES, Ricardo Lobo, op. cit. 2011, p. 167.
} 
inscrita na norma. Isso porque, além da dificuldade em definir critérios objetivos e subjetivos para classificar a finalidade da norma tributária, nada impede que uma mesma norma desempenhe várias funções.

Ademais, não há rivalidade necessária entre uma norma tributária ter finalidade de arrecadação e de regular comportamentos simultaneamente. ${ }^{144} \mathrm{O}$ verdadeiro contraste existiria em efeitos econômicos diversos contrapostos, como uma norma tributária com a finalidade de distribuir riqueza e de inibir condutas ao mesmo tempo. ${ }^{145}$

Para o autor, a expressão extrafiscalidade padeceria de pouca precisão técnica, uma vez que ora é empregada enquanto o gênero - toda tributação orientada para outros fins que não a arrecadação - e ora é empregada enquanto espécie - a função indutora da tributação, a função distributiva da tributação etc. ${ }^{146}$

Também crítica é a visão de Heleno Taveira Torres, que entende ser mais apropriado falar em uma fiscalidade vinculada a motivos constitucionais, enquanto uma competência tributária, do que em extrafiscalidade enquanto uma finalidade da tributação. $^{147}$

Entretanto, se a distinção concerne apenas à finalidade empregada ao instrumento tributário, sem maiores consequências jurídicas, uma primeira constatação inevitável é o caráter meramente classificatório e doutrinário do conceito. Ainda que simplesmente teórica, nos cumpre indagar: qual o papel desta distinção doutrinária para própria teoria do direito tributário?

${ }^{144}$ SHOUERI, Luís Eduardo. op. cit., p. 29

145 Ibidem, p. 27

146 Ibidem, p. 33/34

${ }^{147}$ TORRES, Heleno Taveira. Incentivos Fiscais na Constituição e o "crédito prêmio de IPI". Revista Fórum de Direito Tributário - RFTD, ano 3, n. 14, 2005, p. 26. Para uma crítica da leitura de Heleno Torres ver : GOUVÊA, Marcus de Freitas. op. cit., pp. 49, 50 e 51. 


\subsubsection{1. - Externalidade e Extrafiscalidade}

Em regra, a pertinência de classificações teóricas se mede pelo quanto as mesmas organizam e sistematizam de maneira mais apropriada o conhecimento acerca de um objeto de análise. Nesse sentido, segue a conhecida afirmação de que não existem classificações certas ou erradas, mas úteis e menos úteis.

Portanto, a classificação de um ato tributário, enquanto extrafiscal, se revelará útil na medida em que facilite a compreensão da tributação, ainda que não se verifique isoladamente em situações reais.

Uma aproximação possível para demonstrarmos a utilidade do conceito de extrafiscalidade é traçarmos um paralelismo com o conceito de externalidade e o papel por ele desempenhado na ciência econômica.

Michel Callon, um dos representantes da nova sociologia econômica, afirma que nenhum conceito é mais útil para compreender o funcionamento de um mercado do que o de externalidade. ${ }^{148}$

Por definição, externalidade significa o efeito gerado por uma relação econômica para terceiros que dela não participam. Por exemplo, imaginemos o dano gerado a uma eventual plantação de laranjas pela poluição produzida por uma indústria que venha a se instalar em suas proximidades. A atividade econômica da indústria gerará efeitos sobre a atividade econômica da agricultura, a despeito desta última permanecer completamente externa à relação econômica produtiva da primeira. ${ }^{149}$

Segundo Callon, o conceito de externalidade cumpre, para o método da economia, o papel de designar todos os efeitos decorrentes de uma relação de mercado que os agentes que dela participam não levam em conta ao realizarem-na:

It is for these relations which remain outside the frame that economists reserve the term externalities. The later denotes everything which the agents do not take into account and which enables them to conclude their calculations. ${ }^{150}$

148 CALLON, Michel. An Essay on Framing and Overflowing: Economic Externalities Revisited by Sociology. In: CALLON, Michel (ed). The Laws of the Markets. Oxford: Blackwell Publishers, 1998, p. 244. ${ }^{149}$ Ibidem, p. 245.

${ }^{150}$ CALLON, Michel. Actor-network Theory - the Market Test. In: LAW, John; and HASSARD, John (ed). Actor Network Theory: and After. Oxford: Blackwell Publishers, 1999, p. 188. 
Argumenta o autor que a delimitação das variáveis existentes é uma condição indispensável para que a teoria econômica ortodoxa possa, por meio de seus cálculos, apontar uma solução como a mais eficiente. ${ }^{151}$

Sem buscarmos nos aprofundar em maiores desdobramentos da sociologia de Callon, ou mesmo nas vertentes da sociologia econômica e sua contribuição para compreensão do mercado, acreditamos que essa exposição esquemática já é suficiente para, voltando ao debate da teoria jurídica, apontarmos algumas semelhanças entre os conceitos de externalidade e extrafiscalidade e o papel por eles desempenhado.

Nesse sentido, nos parece que o conceito de extrafiscalidade cumpre semelhante função na compreensão da tributação. Revela os limites de uma teoria normativa sobre o direito tributário - entendido aqui enquanto direito positivo.

Primeiramente, porque a despeito das mudanças incorporadas pela doutrina - e ainda que nos marcos de uma doutrina valorativa de interpretação, a extrafiscalidade possa ser encarada enquanto um princípio orientador da aplicação do direito tributário $^{152}$ - o conceito de finalidade extrafiscal da tributação sempre serviu como um ponto fronteiriço e limítrofe para o direito tributário, apontando efeitos da tributação sobre o comportamento de terceiros.

Paulo de Barros Carvalho afirma categoricamente que a extrafiscalidade não corresponde à entidade jurídica, mas a um acontecimento que cabe melhor nas categorias da Política Tributária ou Economia Tributária correspondentes às Ciências das Finanças. ${ }^{153}$

Em parte, porque, assim como o conceito de externalidade para a teoria econômica ortodoxa, a extrafiscalidade remete a um conjunto de relações e efeitos que não fazem parte da relação tributária entre o Fisco e o contribuinte. A dogmática e a doutrina do direito tributário, voltados a produzir soluções para conflitos entre o Estado e o cidadão recolhedor de tributos, necessitava delimitar a análise da tributação à análise do regime jurídico desta relação.

Walter Barbosa Corrêa, em 1964, constatava:

${ }^{151}$ CALLON, Michel. Introduction: The Embeddedness of Economic Markets in Economics. In: CALLON, Michel (ed). The Laws of the Markets. Oxford: Blackwell Publishers, 1998, pp. 6-12.

${ }^{152}$ Vide: GOUVÊA, Marcus de Freitas. op. cit., p. 42.

${ }^{153}$ CARVALHO, Paulo de Barros. O Instituto da Isenção como Instrumento de Extrafiscalidade, Projeção: Revista Brasileira de Tributação e Economia, ano I, nº 11, out/1976, pp. 32-38. 
Mas, se hoje, entre os recentes autores da matéria de finanças, predomina a idéia da importância de extrafiscalidade, impressiona a circunstância de que tal fenômeno financeiro ainda não mereceu uma definição. Estendem-se uns autores em considerações sôbre os efeitos dos tributos extrafiscais; outros, sôbre as formas de aplicá-los; outros, ainda, nos modelos existentes no direito positivo, dando todos êles, é certo, uma idéia do que seja o fenômeno, sem, contudo, se importarem com a sua essência. ${ }^{154}$

É curioso, no entanto, que a classificação proposta pelo autor também não foi capaz de ir além da apreensão formal do fenômeno. ${ }^{155}$ Percebe-se do quadro que as finalidades políticas que dão conteúdo à extrafiscalidade, as causas possíveis de motivar o incentivo ou o desincentivo de comportamentos, não são cogitadas.

Não por outro motivo, Gustavo do Amaral Martins reitera a constatação, mais de 40 anos depois: a grande maioria dos tributaristas brasileiros passam ao largo das relações entre a ordem tributária e a ordem econômica ${ }^{156}$ e que, no plano geral, a extrafiscalidade é tratada como um tema marginal. ${ }^{157} \mathrm{Na}$ mesma linha, Marcus de Freitas Gouvêa afirma que poucos são os livros de Direito Tributário que fazem menção à questão da extrafiscalidade, mas, da mesma forma, poucos são os que se aprofundam no tema. ${ }^{158}$

A extrafiscalidade, portanto, é um importante ponto de referência para o sistema, e embora tenha despertado grande interesse acadêmico ${ }^{159}$ seu tratamento nunca pôde ir muito além de sua conceituação. Um recurso para realizar o recorte analítico da doutrina, reservando como além do alcance da disciplina as utilizações da tributação relativas às relações entre o regulador e o mercado. De tal maneira que o poder estatal de regular a atividade econômica por meio da indução tributária passou como uma

\footnotetext{
${ }^{154}$ CORREAA, Walter Barbosa. op. cit., p. 46.

${ }^{155}$ Walter Barbosa Corrêa propunha classificar a extrafiscalidade com base em dois elementos: a forma e a intensidade de manifestar-se. Nesse sentido, a extrafiscalidade poderia ser explícita (quando manifestada em imunidades, isenções ou reduções) ou implícita (quando manifestada em tributos e empréstimos compulsórios). Quanto à intensidade, essa poderia ser total ou parcial nos casos de extrafiscalidade explícita, e preponderante, média ou não preponderante nos casos de extrafiscalidade implícita. In: CORRÊA, Walter Barbosa. op. cit., pp. 68-70.

156 AMARAL MARTINS, Gustavo do. Mercado e Tributação: Os Tributos, sua relação com a Ordem Econômica e a Necessidade de Considerá-la na Interpretação e Aplicação do Direito Tributários. In: DOMINGUES, José Marcos (coord.). Direito Tributário e Políticas Públicas. Belo Horizonte: MP. 2008, p. 137.

${ }^{157}$ Ibidem, p. 138.

${ }^{158}$ GOUVÊA, Marcus de Freitas. op. cit., p. 1

${ }^{159}$ Para um panorama substancial sobre os principais autores que se debruçaram sobre o tema ver: A esse respeito ver: SHOUERI, Luís Eduardo. op. cit. 2005, p. 32.
} 
dimensão econômica da tributação não pertinente ao direito tributário e tida, muitas vezes, como ajurídica.

\subsection{2. - A Extrafiscalidade enquanto objeto do Direito Econômico}

Retomando o argumento de Michel Callon, outra característica do conceito de externalidade é que ao se situar em uma zona cinzenta entre a teoria econômica e a sociologia, se revela um promissor ponto de cooperação entre ambas. ${ }^{160}$ Porque ao mesmo tempo em que impõe um recorte da realidade necessário para o método da ciência econômica, deixa um rastro do que "sobrou" desse recorte, os retalhos da realidade que não foram tratados, revelando uma porta para a sociologia descrever todo contexto que circunda e enraíza essas relações de mercado. ${ }^{161}$

Dessa maneira, a sociologia poderia complementar o quadro traçado pela economia tradicional esmiuçando as diversas relações sociais que compõem as externalidades e permitindo a construção de saídas para as falhas de mercado de uma perspectiva mais ampla do que a dos agentes envolvidos naquele mercado.

Em análise, se a extrafiscalidade aponta para um recorte e um limite da doutrina do direito tributário, a questão que fica é: como solucionar os conflitos existentes na tributação com finalidades regulatórias? É nesse ponto, em particular, que a análise do direito econômico se demonstra pertinente e promissora.

O estudo da extrafiscalidade abre caminho para que o direito econômico, por meio de uma abordagem pluridisciplinar, cuide dessa dimensão que foi preterida pelo direito tributário; permitindo, assim, que se possa auferir a política econômica veiculada pela norma e reconstruir as relações tributárias, observando os efeitos extrafiscais por ela produzidos, até mesmo limitando-as.

Principalmente, na medida em que a finalidade extrafiscal da norma tributária corresponde, justamente, ao princípio da economicidade - vocação deliberada para intervir no espaço econômico - e, dessa forma, apresentando-se como verdadeiro ponto de contato entre as duas disciplinas.

160 CALLON, Michel. An Essay on Framing and Overflowing: Economic Externalities Revisited by Sociology. In: CALLON, Michel (ed). The Laws of the Markets. Oxford: Blackwell Publishers, 1998, p. 244.

${ }^{161}$ Ibidem, pp. 247 e 248. 
Isso porque, se para o direito tributário a extrafiscalidade remete ao emprego excepcional de instrumentos tributários com finalidades não arrecadatórias, para o direito econômico a dimensão extrafiscal da tributação é uma das formas mais comuns de intervenção estatal sobre o espaço econômico que pode, eventualmente, visar apenas à arrecadação de recursos.

Nesse sentido, partilhamos do diagnóstico de Marcus de Freitas Gouvêa de que o método a ser empreendido da análise da extrafiscalidade é o do direito econômico:

\begin{abstract}
O Direito Tributário adota a metodologia pura do Direito, sobremodo afeita à compreensão da fiscalidade, dos institutos que lhe são próprios e da conformação da norma tributária. Não obstante, quando suas preocupações dirigem-se às finalidades extrafiscais e a sua eficácia, o enfoque deve ser pluridisciplinar.

(...)

Dessa forma, o método se aproxima daquele apontado por Washington Peluso Albino de Souza, para quem o Direito Econômico adota o método Analítico Substancial, que conjuga, em metodologia pluridisciplinar, a análise econômica e a análise jurídica, com prevalência do princípio da economicidade. ${ }^{162}$
\end{abstract}

Esse desafio se dá em dois momentos: na análise das finalidades extrafiscais das próprias normas do sistema tributário brasileiro e na análise dos instrumentos jurídicos para atuação conjuntural e dinâmica do Estado, balizada por essas normas. Porque se é verdade que no próprio desenho estático do sistema tributário já se está veiculando, em certa medida, uma política tributária, também é verdade que os atos de tributação extrafiscais do Estado podem ser executados por meio de inúmeros instrumentos e em busca de diversos objetivos. ${ }^{163}$

A constituição brasileira, ao dispor os contornos básicos, os princípios fundantes e legitimadores da tributação, encerra uma dimensão política e econômica da tributação. Da mesma forma que as decisões, muitas vezes infralegais, de alteração de alíquotas, isenção de tributos, criação de contribuições entre outras medidas, também compõem o quadro geral da dimensão extrafiscal da tributação brasileira.

A intervenção estatal na economia em um Estado de Direito se dá sob a égide de uma constituição econômica. De tal modo, que a dimensão extrafiscal da tributação

${ }^{162}$ GOUVÊA, Marcus de Freitas. op. cit., p. 14/15.

${ }^{163} \mathrm{LOBO}$, Rogério Leite. Os Atos de Tributação Interventivos no Domínio Econômico: Proposta de Classificação e Considerações sobre o seu Regime Jurídico. In: Revista de Direito Administrativo, Vol. 232, Rio de Janeiro, 2003, pp. 33-35. 
toma a forma de valores constitucionais positivados. ${ }^{164}$ Não apenas enquanto fundamentos da mesma, mas enquanto finalidades constitucionalmente abrigadas ou não.

$\mathrm{Na}$ medida em que princípios, valores e objetivos constituem as finalidades da intervenção econômica do Estado, se faz necessário que a utilização da tributação, voltada a produzir efeitos na economia, seja interpretada à luz de suas consequências, dos efeitos que procura produzir. Tal tarefa é parte do controle de constitucionalidade das leis: averiguar se a atuação estatal pretendida encontra-se de acordo com os princípios da ordem econômica e com a repartição de competências estabelecidas na constituição.

A extrafiscalidade é o campo de desenvolvimento da política fiscal do Estado por meio da tributação. Política esta que se caracteriza por ser dinâmica e conjuntural. ${ }^{165}$ Como assevera Fábio Konder Comparato, o direito econômico tem por missão compreender e analisar a política econômica do Estado. ${ }^{166}$

Incentivos e desincentivos tributários são técnicas para desempenhar a política industrial, a política monetária, o controle de capitais, a distribuição de renda, o crescimento econômico, a procura pelo pleno emprego, a concorrência e todos demais objetivos constitucionalmente buscados pela política econômica.

Nesse sentido, a análise da extrafiscalidade da tributação se revela um ponto privilegiado para o direito econômico na análise da tributação. Por meio dela, ele pode contribuir - enquanto técnica de análise da política econômica veiculada pela dimensão extrafiscal da tributação - para crítica e posterior proposição de saídas para as próprias soluções encontradas pela legislação tributária, tendo em vista a sua capacidade de concretizar, por meio de políticas públicas, a constituição econômica. ${ }^{167}$

Em certa medida, essa perspectiva se assemelha à complementaridade com o que a doutrina tributária convencionou chamar de "Ciência das Finanças". Um estudo dos aspectos políticos, econômicos, institucionais e sociais que envolvem a atividade tributária e sua legislação. ${ }^{168}$ Entretanto, buscamos fugir desta designação por algumas razões. Primeiramente, porque passa a ideia de que a dimensão política, econômica,

${ }^{164}$ GOUVÊA, Marcus de Freitas. op. cit., p. 274.

${ }^{165}$ LOBO, Rogério Leite. op. cit., p. 33.

${ }^{166}$ COMPARATO, Fábio Konder., op. cit., p. 22.

${ }^{167}$ BERCOVICI, Gilberto. op. cit., p. 41.

${ }^{168}$ BALEEIRO, Aliomar. op. cit. 1970, p. 4. 
institucional e social da tributação não é jurídica. ${ }^{169}$ Além disso, porque o que se consagrou como "Ciência das Finanças" foi, de fato, uma abordagem que se caracterizava por tratar de forma normativa e teórica as alternativas e técnicas de condução da política físcal. ${ }^{170}$

A esse respeito Geraldo Ataliba assevera que:

\begin{abstract}
É incontroverso - desde a afirmação da ciência das finanças como autônoma, relativamente à economia política - que a questão central e nuclear do seu complexo objeto é o como, quando, por que processos e com que meios e critérios, repartir entre os membros da sociedade os encargos sociais de natureza material. ${ }^{171}$
\end{abstract}

Por direito econômico da tributação, não buscamos desenhar modelos ideais de como deveria ser a tributação, ainda que possamos opinar criticamente sobre como solucionar impasses da regulação jurídica da tributação com alternativas de lege ferenda.

Procuramos, de um lado, abordar e classificar a estrutura constitucional tributária e sua legislação sobre o prisma das finalidades econômicas. De outro lado, buscamos analisar a estrutura jurídica e o regime de competências da atuação concreta do Estado, pelos mais diversos instrumentos, na execução de políticas fiscais. Partindo da interpretação do direito para a definição da política econômica como uma via de mão dupla, e não apenas da compreensão das alternativas sociais, institucionais, políticas e econômicas como fontes de reformulação do direito positivo ou inspiração interpretativa.

\footnotetext{
${ }^{169}$ Alberto Deodato, que escreveu um dos principais manuais de Ciência das Finanças assim a classificava: A Ciência das Finanças não é uma ciência jurídica. Não é ramo do Direito. Está dentro do quadro das Ciências Políticas. (...) Assim, a Ciência das Finanças mais se entrosa com a Economia Política, com a História, com a Estatística, com a Contabilidade. In: DEODATO, Alberto. op. cit. 1973, p. 12/13.

${ }^{170} \mathrm{Na}$ definição de Aliomar Baleeiro: a Ciência das Finanças observa e descreve fatos e instituições ou investiga causas e efeitos, e, quando aplicada, indica meios para alcançar determinado fim no campo da atividade financeira do Estado ou de outras pessoas de direito político, quer para provimento dos cofres públicos, quer para intervenção governamental na sociedade, isto é, sua utilização extrafiscal. In: BALEEIRO, Aliomar. op. cit. 1984, p 8.

${ }^{171}$ ATALIBA, Geraldo. op. cit. 1969, p. 9.
} 


\section{DOGMÁTICA JURÍDICA DA INTERVENÇÃO ECONÔMICA DO ESTADO PELA TRIBUTAÇÃO}

Uma das facetas do pensamento jurídico, independentemente da forma com que se dê a sua abordagem, é oferecer instrumentos para a superação dos conflitos e a operacionalização das próprias decisões que performam as instituições do Estado. É o papel que Tércio Sampaio Ferraz Jr. designa como a função social da dogmática jurídica: oferecer caminhos e saídas para a decidibilidade de conflitos. ${ }^{172} \mathrm{Um}$ saber tecnológico capaz de limitar e reduzir possibilidades contingentes de ações. ${ }^{173}$

Como argumenta Fernando Aguilar, é inevitável que os trabalhos jurídicos sejam instados a manifestar sua opinião sobre como os fatos deveriam ser. Independente da tradição de pensamento jurídico a que o autor se aproxime, ele terá que lidar com a consequência de que seu enquadramento jurídico dos conflitos sociais ensejará uma solução jurídica para o mesmo, o que, por sua vez, manifestará uma opinião de como esses conflitos deveriam ser superados. ${ }^{174}$

Assim, uma análise funcional do direito tributário positivo, que visa a problematizar a regulação econômica realizada pelo Estado brasileiro por meio da tributação, não pode se furtar a constituir uma dogmática própria de classificação e enquadramento das formas, técnicas, finalidades e competências da intervenção do Estado na economia por meio da tributação. Pois sem uma reflexão interna ao direito, dogmática, dificilmente será possível apontar as eventuais saídas jurídicas para os impasses institucionais encontrados - sejam elas externas, por meio da alteração do próprio direito positivo, ou internas, por meio de novas interpretações possíveis dentro do quadro normativo já constituído por esse direito positivo.

Tendo isso em vista que esse capítulo se arroga a tarefa de debruçar-se sobre o ordenamento constitucional brasileiro e as normas que tratam da instituição,

\footnotetext{
${ }^{172}$ FERRAZ JR., Tercio Sampaio. Função Social da Dogmática Jurídica. São Paulo: Max Limonad, 1998, p. 89-91.

${ }^{173}$ Idem.

${ }^{174}$ AGUILLAR, Fernando Herren. Metodologia da Ciência do Direito. São Paulo: Atlas, 2009, p. 121.
} 
arrecadação e fiscalização dos tributos, classificando-as por uma perspectiva funcional, enquanto meios para consecução de determinados fins, ${ }^{175}$ a análise envolverá, também, uma classificação com base na atuação potencial do Estado na economia por meio das normas jurídicas tributárias. Sua dogmática e seus conceitos se darão na medida em que as mesmas viabilizem, restrinjam ou possibilitem a adoção de determinadas políticas tributárias cujas finalidades estão constitucionalmente estabelecidas.

175 Para um panorama sobre essa abordagem ver: BOBBIO, Norberto. Da Estrutura à Função: Novos Estudos de Teoria do Direito. Trad. Daniela Beccaccia Versiani. Barueri: Manole, 2007, p. 81-113. 


\section{1 - Formas de Intervenção}

As formas de atuação do Estado na economia previstas na constituição brasileira de 1988 foram objeto de grande esforço classificatório por Eros Grau. Em seu trabalho, A Ordem Econômica na Constituição de $1988,{ }^{176}$ o professor buscou exaustivamente uma interpretação uníssona do conjunto de dispositivos constitucionais que versam sobre a forma de atuação do Estado em relação ao processo econômico para, posteriormente, classificá-la em um arcabouço dogmático do direito econômico.

Uma primeira constatação de Eros Grau é que a constituição de 1988 se refere à expressão atividade econômica com sentidos diversos. Em determinados momentos, reportando-se ao termo em sentido amplo, enquanto gênero - o que inclui atividades econômicas ilícitas, atividades econômicas estritas, típicas do setor privado, e o serviço público, típico do setor público. Em outras passagens, a constituição se reporta ao termo enquanto espécie - somente às atividades econômicas em sentido estrito, típicas do setor privado. ${ }^{177}$

Tendo isso em vista, ele propõe referir-se à atuação- em substituição ao vocábulo intervenção - do Estado na economia quando se mencione as atividades econômicas em sentido amplo (incluídas aqui as atividades ilícitas e o serviço público), reservandose a ideia de intervenção do Estado na economia para designar apenas a atuação estatal referente à atividade econômica em sentido estrito, pois o termo intervenção remete à atuação estatal no domínio de outrem, logo, na esfera do privado. ${ }^{178}$

Seguindo essa trilha Eros Grau classifica em duas formas a intervenção do Estado no domínio econômico e em quatro modalidades possíveis.

Quanto à forma, ela pode ocorrer "no" domínio econômico ou "sobre" o domínio econômico. Ela se dá "no" domínio econômico quando o Estado atua no campo da atividade econômica como se agente econômico fosse, desempenhando ações como um partícipe do mercado. ${ }^{179}$ Ela se dá "sobre” o domínio econômico quando o Estado atua

${ }^{176}$ GRAU, Eros Roberto. op.cit.

${ }^{177}$ Ibidem, pp. 103 e 104.

${ }^{178}$ Ibidem, p. 148.

${ }^{179}$ Idem. 
no campo da atividade econômica enquanto regulador, alterando as variáveis do próprio mercado. ${ }^{180}$

Quanto às modalidades, a intervenção "no" domínio econômico pode se dar por absorção ou por participação, respectivamente, quando o Estado assume uma determinada atividade econômica e passa a exercê-la sob regime de monopólio (absorção), ou quando o Estado assume parte de uma determinada atividade econômica e passa a exercê-la em regime de competição com empresas privadas (participação). ${ }^{181}$

A intervenção "sobre" o domínio econômico pode se dar por direção ou por indução, respectivamente, quando o Estado estabelece normas de comportamento compulsórias, imperativas, aos agentes que exercem uma dada atividade econômica (direção), ou quando o Estado manipula os instrumentos de intervenção, em consonância e conformidade com as regras que regem o funcionamento do mercado, de forma a levar os agentes que exercem uma dada atividade econômica a optarem por um determinado comportamento em detrimento de outro (indução). ${ }^{182}$

É nessa última categoria que se enquadra a dimensão extrafiscal das normas tributárias. Pela própria natureza da tributação, não há dúvida de que a capacidade de intervenção estatal por meio delas ocorre "sobre" o domínio econômico. A competência tributária é uma prerrogativa exclusivamente estatal e sempre será utilizada pelo mesmo como forma de atuação enquanto regulador e jamais enquanto agente de mercado.

A própria definição da finalidade extrafiscal da tributação já a consagra como a sua utilização com finalidade regulatória, no exercício de seu poder de polícia, de limitar a liberdade privada em razão do interesse coletivo.

180 Idem.

181 Idem.

182 Ibidem, pp. 149 e 150. 


\title{
2.1.1 - Indução
}

Essa regulação econômica do Estado pela tributação é uma regulação indutora, que acena uma vantagem ou uma desvantagem ao contribuinte diante de uma determinada conduta. ${ }^{183}$

A indução é a forma que caracteriza a utilização do instrumento tributário para intervir sobre o espaço econômico, principalmente porque a tributação pressupõe a possibilidade do sujeito passivo incorrer ou não no fato gerador do tributo. ${ }^{184} \mathrm{~A}$ ação ou a omissão gravada de maior ou menor ônus tributário não significa que a conduta desincentivada seja ilícita. Muito pelo contrário, é certo que ela seja lícita. Não há sanção ao agente por não se conduzir de acordo com a indução tributária, mas, sim, incidência de ônus tributário.

Admitir a possibilidade de uma intervenção tributária por indução significaria admitir a obrigação de o sujeito passivo incorrer no fato gerador do tributo, o que seria um paradoxo. ${ }^{185}$

Nesse sentido, a intervenção indutora visa, pela gramática de incentivos, a levar o próprio mercado a escolher o quanto e de que maneira adotará o comportamento almejado pela regulação estatal. Dessa forma, atua em consonância com as próprias regras e lógica de funcionamento do próprio mercado. A esse respeito, pondera Eros Grau:

\begin{abstract}
A sedução à adesão ao comportamento sugerido é, todavia, extremamente vigorosa, dado que os agentes econômicos por ela não tangidos passam a ocupar posição desprivilegiada nos mercados. Seus concorrentes gozam, porque aderiram a esse comportamento, de uma situação de donatário de um determinado bem (redução ou isenção de tributo, preferência à obtenção de crédito, subsídio, v.g.), o que lhes confere melhores condições de participação naqueles mercados. ${ }^{186}$
\end{abstract}

Apesar de a majoração do ônus tributário ser, na maioria das vezes, de natureza econômica, a economicidade que afeta o instrumento tributário está na finalidade

${ }^{183}$ CORRÊA, Walter Barbosa. op. cit., p. 29

${ }^{184}$ SHOUERI, Luís Eduardo. op. cit., p. 46.

${ }^{185} \mathrm{Idem}$

${ }^{186}$ GRAU, Eros Roberto. op.cit., p. 150. 
econômica da desoneração e não no benefício econômico auferido pelo contribuinte. Fato esse que merece destaque, pois por vezes a intervenção estatal sobre o domínio econômico por indução tributária, desoneradora ou oneradora, não implica na concessão de vantagens econômicas ou pecuniárias aos contribuintes.

É o caso da simplificação de obrigações tributárias acessórias, como estabelecido na Lei Complementar $\mathrm{n}^{\circ} 123$ de 2006. O regime do SIMPLES nacional, instituído por ela, estabelece normas gerais relativas ao tratamento diferenciado e favorecido a ser dispensado às microempresas e empresas de pequeno porte no âmbito dos poderes da União, dos estados, do Distrito Federal e dos municípios. Nota-se que tal regime representa uma significativa redução de custo para o pequeno empresário, todavia grande parte do incentivo reside na facilitação para o cumprimento das obrigações acessórias da tributação.

Embora seja descabido elucubrar uma intervenção tributária sobre o domínio econômico por direção - por normas de comportamento compulsório, comandos imperativos, dotados de cogência e impositivos de determinados comportamentos a serem necessariamente cumpridos pelos agentes ${ }^{187}$ - alguns exemplos de intervenção estatal sobre o espaço econômico pela tributação chegam a se aproximar desse arquétipo. São as chamadas finalidades extrafiscais distributivas da tributação, que permitem uma margem muito estreita aos sujeitos passivos de não realizarem os seus fatos geradores.

É o caso, por exemplo, da tributação progressiva da renda, da sobretaxação de bens de consumo supérfluo, ou da subtaxação de bens essenciais. Embora haja uma clara intervenção econômica do Estado nos três casos, que objetiva produzir efeitos específicos na economia antes de elevar a arrecadação de recursos financeiros, não podemos dizer que o Estado pretenda, com essa tributação, que o contribuinte aufira uma renda menor, consuma menos bens supérfluos ou mais bens essenciais.

Ainda que essa intervenção possa promover um incentivo ao investimento da renda em atividades dedutíveis - como no incentivo à cultura, previsto na Lei 8.313/91, a chamada lei Rouanet - um desincentivo à produção de bens supérfluos e um incentivo à produção de bens essenciais, seu objetivo claro é atuar redistributivamente nessas três

${ }^{187}$ Ibidem, p. 149. 
hipóteses, atenuando a concentração de renda e a regressividade de todo o sistema tributário.

A indução, nas três hipóteses, se vier a ocorrer, é mediata. Sobretudo porque a capacidade do contribuinte esquivar-se de realizar os fatos geradores, embora exista, é baixíssima e, mais do que isso, não é propriamente o objetivo da regulação estatal promovida pela tributação. A tributação municipal do IPTU ajuda a tornar esse fato ainda mais claro.

A constituição brasileira prevê três hipóteses de aplicação de alíquotas progressivas de IPTU pelo município. Pode ele vir a ser cobrado com alíquotas progressivas no tempo, caso o proprietário do solo urbano - não edificado, subutilizado ou não utilizado - não promova seu adequado aproveitamento (art. 182, $\S 4^{\circ}$, inciso II); poderá ter a progressividade exigida conforme a localização e o uso do imóvel $\left(156, \S 1^{\circ}\right.$, inciso II) e poderá ser progressivo em razão do valor do imóvel (156, $\S 1^{\circ}$, inciso I).

Embora seja bastante claro que as primeiras duas hipóteses representam uma intervenção indutora do Estado no espaço econômico, tendo em vista que o município possa incentivar, por meio do agravamento do ônus fiscal, o proprietário a promover o adequado aproveitamento da propriedade, ou que possa incentivar a ocupação urbana de determinadas regiões com determinadas atividades econômicas, também é claro que a progressividade do IPTU em razão do valor do imóvel não consiste em um incentivo à desvalorização imobiliária. A progressividade, aqui, visa a cumprir com o princípio da capacidade contributiva, redistribuir a renda, e não induzir a venda de imóveis de valores mais baixos, ainda que venha a gerar esse efeito.

Nesses casos, a intervenção econômica do Estado chega a se assemelhar à intervenção por direção, imputando o ônus tributário a determinadas atividades e condutas como forma de regular a distribuição da renda na sociedade. Entretanto, mesmo nesses casos, ainda há margem de escolha para o contribuinte, pois mesmo que o prejuízo econômico decorrente de não realizar o fato gerador do tributo seja superior ao desincentivo de realizá-lo, ainda existe a opção. Caso não houvesse a mesma, estaríamos diante de uma hipótese de confisco, o que descaracterizaria a tributação e cujo efeito não é permitido por nossa ordem constitucional (art. 150, inciso IV). 


\section{2 - Técnicas de Intervenção}

As técnicas de intervenção tributária podem ser diversas, a depender do critério a que sua análise se pautar. Partindo-se das vias de realizá-la, por exemplo, seria infindável o trabalho de classificação.

Por se tratar de uma intervenção por indução, em que o Estado manipula os instrumentos de intervenção em consonância das leis que regem o mercado, ${ }^{188}$ a possibilidade de meios para incentivá-lo é enorme. Pode acontecer pela criação de novos tributos ou pela sua isenção, pela alteração de alíquotas, pela concessão de moratória, pela criação de regimes especiais de parcelamento, pela concessão de créditos fiscais, pela remissão, entre outras formas a serem vislumbradas pela autoridade estatal.

Tendo isso em vista, da perspectiva do direito econômico, nos parece mais pertinente uma classificação que parta da perspectiva da ação do Estado, sem a pretensão de esgotar as inúmeras técnicas possíveis de serem adotadas para reduzir o ônus tributário. Uma definição abrangente que possa abarcá-las conjuntamente.

Nesse sentido, se partirmos dos efeitos que essas técnicas visam produzir na conduta de agentes econômicos racionais as técnicas de indução tributária podem ser divididas em basicamente duas: a desoneração e a oneração. A esse respeito Aliomar Baleeiro já advertia:

Quando pretende uma intervenção através de processos tributários, o Estado ora usa dos efeitos drásticos que uma imposição produz sobre os preços e o valor, conforme vimos a propósito dos fenômenos de repercussão, absorção e transformação, ora afasta esses efeitos através de imunidades e isenções, discriminando, para esse fim, as coisas, fatos ou atividades, que deseja preservar ou encorajar. ${ }^{189}$

Ambas pretendem induzir o comportamento dos agentes proporcionando-lhes vantagens econômicas em decorrência de uma evasão fiscal lícita, ${ }^{190}$ ou seja, da adoção

\footnotetext{
${ }^{188}$ Ibidem, p. 149.

${ }^{189}$ BALEEIRO, Aliomar. op. cit. 1984, p. 177.

${ }^{190}$ Ibidem, p. 152.
} 
de um comportamento que lhe enseje um menor ônus tributário, seja evitando uma determinada conduta ou condição, seja optando por ela.

\subsection{1 - Desoneração}

Por técnicas desoneratórias, ou de fomento, podemos elencar todas as medidas que reduzem o ônus tributário diante de determinadas condutas adotadas pelos contribuintes. São técnicas que concedem vantagens aos contribuintes que adotarem o comportamento por ela previsto, levando o contribuinte a conduzir-se nesse sentido.

Sacha Calmon Navarro Coelho abordou o tema sob uma perspectiva da teoria da norma tributária desoneradora, buscando classificar o que chamou de técnicas exoneratórias, tomando como critério a norma que estabelece a relação obrigacional tributária. Ao fazê-lo, separou-as em técnicas internas ou externas às normas tributárias impositivas. ${ }^{191}$ As internas poderiam ser subdividas entre técnicas qualitativas ou quantitativas. As primeiras, presentes na hipótese normativa, seriam os casos das isenções e imunidades. As segundas, presentes na consequência normativa, seriam os casos de concessão de créditos presumidos ou reduções de alíquotas ou alterações de base de cálculo. ${ }^{192}$ As técnicas exoneratórias externas seriam as decorrentes de novas normas específicas criando, por exemplo, a remissão ou a devolução de tributos já recolhidos. $^{193}$

As formas de fomentar condutas por desoneração tributária são diversas. Exemplificativamente, podem ocorrer pelas modalidades de suspensão da exigibilidade do crédito tributário, previstas no art. 151 do CTN (como no caso dos parcelamentos do REFIS e do PAES), ${ }^{194}$ pelas modalidades de extinção do crédito tributário, previstas no art. 156 do CTN (como na remissão), pelas modalidades de exclusão do crédito tributário, previstas no art. 175 do CTN (como na hipótese de isenção ou anistia), pela redução de alíquotas de tributos (como no caso de incentivos fiscais para determinadas

\footnotetext{
${ }^{191}$ NAVARRO COELHO, Sacha Calmon. Teoria Geral do Tributo e da Exoneração Tributária. $2^{\text {a }}$. Ed. Belo Horizonte: Del Rey, 1999, p. 143-232. Ver também: GOUVÊA, Marcus de Freitas. op. cit., pp. 214 e 215.

${ }^{192}$ NAVARRO COELHO, Sacha Calmon. op. cit., pp. 143 e 232.

${ }^{193}$ Idem.

${ }^{194}$ A esse respeito ver: GOUVÊA, Marcus de Freitas. op. cit., pp. 243, 244 e 281.
} 
atividades) ou até pela não tributação de uma atividade constitucionalmente ressalvada (como no caso de observância de uma imunidade constitucional).

Dessa forma, temos que a desoneração consiste na utilização do instrumento tributário para incentivar determinadas condutas, por meio da redução do ônus tributário, pela diminuição do valor a ser recolhido pelo contribuinte ou de seus deveres instrumentais, com vistas a alcançar objetivos da política econômica do Estado. ${ }^{195}$

\subsection{2 - Oneração}

Quanto às técnicas oneratórias, ou de inibição, podemos elencar todas as medidas que agravam o ônus tributário diante de determinadas condutas adotadas pelos contribuintes. São técnicas que geralmente procuram desestimular condutas, aumentando o custo para o contribuinte que adotar o comportamento previsto por elas, induzindo-o a conduzir-se de forma alternativa.

De uma perspectiva normativa, podemos nos valer do quadro traçado por Sacha Calmon para as técnicas exoneratórias e reproduzi-lo, apenas invertendo o seu sinal.

Como técnicas internas e qualitativas, temos a criação de tributos sobre determinadas atividades antes isentas, por exemplo, por meio de uma Contribuição de Intervenção no Domínio Econômico, ou mesmo a revogação de isenções. Como técnicas internas e quantitativas, a elevação de alíquota ou da base de cálculo. No caso das técnicas oneratórias externas, no entanto, nos parece que as mesmas seriam incompatíveis com os princípios da estrita legalidade e da irretroatividade, previstos na constituição no art. $5^{\circ}$, inciso XXXVI e no art. 150, inciso III, alínea "a" e no CTN nos arts. 105 e 106. Ademais, não haveria como agravarem-se tributos já recolhidos ou já remitidos.

Como podemos extrair do quadro, o rol de técnicas oneratórias de indução tributária parece ser bem mais restrito que o de técnicas desoneratórias. Ainda assim, podemos elencar inúmeras hipóteses de técnicas oneratórias: a majoração de alíquotas progressivas sobre imóveis rurais e urbanos improdutivos (art. XX da CF). A elevação

${ }^{195}$ SOUZA, Washington Peluso Albino de. op. cit., p. 3. 
de alíquotas seletivas sobre bens supérfluos, a criação de contribuições interventivas, a redução de atividades dedutíveis do imposto de renda etc.

A oneração, portanto, consiste na utilização do instrumento tributário para desincentivar determinadas condutas, por intermédio do aumento do ônus tributário, pela elevação do valor a ser recolhido pelo contribuinte ou de seus deveres instrumentais, com vistas a alcançar objetivos da política econômica do Estado. ${ }^{196}$ Nesse sentido, a revogação de benefícios fiscais também pode ser uma técnica oneratória de indução tributária.

${ }^{196}$ Idem. 


\title{
2.3 - Finalidades da Intervenção
}

É na classificação das finalidades da intervenção estatal sobre o domínio econômico por indução tributária, por técnicas oneratórias ou desoneratórias, que cumpre retomar o debate acerca da categoria da extrafiscalidade. ${ }^{197}$

As motivações para tributação extrafiscal também podem ser variadas. Entretanto, como qualquer intervenção do Estado no domínio econômico, não pode se furtar a ter escopo na constituição. A esse respeito, pondera Marcus de Freitas Gouvêa:

\begin{abstract}
10 - Entre os objetivos constitucionais que justificam o manejo do instrumento tributário destacam-se, entre outros, o desenvolvimento econômico, que detalha na acumulação de capital, na busca pelo pleno emprego, na distribuição da renda e riqueza, na geração de tecnologia, na preservação do meio ambiente, no desenvolvimento urbano, no desenvolvimento rural e na reforma agrária, além do desenvolvimento sociocultural, representado pela proteção da família, pela promoção da seguridade social e pelo incentivo à cultura, à educação, e ao desporto. Não basta, para justificar a constitucionalidade de uma norma, a mera alegação de extrafiscalidade. É necessário que a extrafiscalidade coincida com o valor (objetivo) constitucional e que este seja suficiente para legitimar a norma extrafiscal. $^{198}$
\end{abstract}

A constituição brasileira de 1988 é uma constituição dirigente, pois além de estabelecer as regras do jogo econômico, incorpora um programa de transformações sociais e econômicas que devem orientar o processo econômico. ${ }^{199}$

Como em regra a todas as constituições, ela não possui uma definição organizada de todos os fundamentos para ação econômica do Estado, contudo prevê seus fundamentos de forma esparsa pelo seu texto. De outra banda, a intervenção sobre o domínio econômico por indução tributária nunca se dá de forma isolada, atendendo apenas a um desses fundamentos, mas é fruto de uma ponderação de todo o sistema e almeja múltiplos objetivos.

\footnotetext{
197 “Quando os impostos são empregados como instrumento de intervenção ou regulação pública, a função fiscal propriamente dita, ou "puramente fiscal", é sobrepujada pelas funções "extrafiscais". A sua técnica é, e então, adaptada ao desenvolvimento de determinada política ou diretriz." In: BALEEIRO, Aliomar. op. cit. 1984, p. 176.

${ }^{198}$ GOUVÊA, Marcus de Freitas. op. cit., pp. 279 e 280.

199 BERCOVICI, Gilberto. Direito Econômico do Petróleo e dos Recursos Minerais. São Paulo: Quartier Latin, 2011, pp. 208 - 211
} 
Para Gilberto Bercovici, em uma perspectiva finalística, a constituição econômica tem por funções a ordenação da atividade econômica, a satisfação das necessidades sociais, a direção do processo econômico e a transformação da estrutura social. ${ }^{200}$

\begin{abstract}
A função de ordenação da atividade econômica diz respeito à instituição da ordem pública econômica, ou seja, das regras do jogo econômico, especialmente as limitações à liberdade econômica (artigos 170, II, III, IV, V, VI e IX, 172, $173, \S 4^{\circ}, 174,179$ da Constituição de 1988 , entre outros). A satisfação das necessidades sociais aparece de forma explícita na previsão de direitos sociais e econômicos e nos dispositivos relativos aos serviços públicos (artigos $6^{\circ}, 7^{\circ}, 8^{\circ}$, $9^{\circ}, 21$, X, XI e XII, 175, 178, 194, 196, 199, 201, 203, 205, entre outros). A política econômica constitucional está incluída na função de direção do processo econômico geral, como nos dispositivos relativos ao desenvolvimento, pleno emprego, política monetária e distribuição de renda (artigos $3^{\circ}$, II e III, 21, VII, VIII e IX, 164, 170, VII e VIII, 176, 177, 192, entre outros). Finalmente, a função transformadora da constituição econômica está prevista nos objetivos da República (artigo $3^{\circ}$ ), na reforma urbana e na reforma agrária (artigos 182 a 191), entre outras disposições espalhadas pelo texto constitucional. ${ }^{201}$
\end{abstract}

Nesse sentido, cabe à doutrina do direito econômico, de perfil funcional, simultaneamente expor o ordenamento constitucional da economia e traduzir juridicamente a economia. ${ }^{202}$ Realizar um esforço de classificação dogmática dessas motivações constitucionais da extrafiscalidade, de forma a apurar o juízo acerca das mesmas.

Centrados nesse contexto, buscamos inspiração na obra do economista de Richard A. Musgrave, para classificarmos em três categorias distintas a intervenção sobre o domínio econômico por indução tributária.

Em sua principal obra, Teoria das Finanças Públicas, Musgrave se propunha a desenvolver uma teoria robusta para o setor público da economia. Um trabalho que abordasse a questão mais da perspectiva normativa, estabelecendo regras e princípios de uma gestão eficiente da economia pública, do que de uma perspectiva sociológica, que pudesse explicar o porquê de certas políticas serem seguidas e outras não. ${ }^{203}$

Nosso modelo normativo de economia pública não tem a intenção de ser
realístico, no sentido de descrever o que se passa nas capitais do mundo. Ao
invés, destina-se a demonstrar o que aconteceria se fosse atingido um resultado

${ }^{200}$ BERCOVICI, Gilberto. op. cit., p. 210.

${ }^{201}$ Idem.

202 COMPARATO, Fabio Konder. op. cit., 1965 p. 20.

${ }^{203}$ MUSGRAVE, Richard A. op. cit, p. 24. 
ótimo. Não obstante, nosso modelo não deixa de estar em relação íntima com as instituições econômicas e sociais. ${ }^{204}$

Seguindo essa trilha, Musgrave envereda pelas questões econômicas da política fiscal e a interação entre tributação e gasto orçamentário sobre as diversas áreas da economia, problematizando e prescrevendo modelos econômicos para determinação das melhores soluções para os ajustamentos entre o trabalho e a produção, o consumo e o investimento, a acumulação de capital e a distribuição de renda, o crescimento e a estabilidade.

Para ele, em um Estado ideal, de planejamento eficiente, as finalidades da política fiscal poderiam ser agrupadas em três ramos: a utilização de instrumentos fiscais para alocação de recursos na sociedade; a utilização de instrumentos fiscais para promover ajustes na distribuição de renda e riqueza; e a utilização de instrumentos fiscais para garantir a estabilização econômica. ${ }^{205}$

Sob esse enquadramento, os tipos e formas dos tributos são ponderados e avaliados diante dos resultados potenciais que poderão proporcionar em cada divisão. A questão da tributação proporcional ou progressiva da renda; a seletividade da tributação do consumo e sua realização por impostos unitários ou ad valorem; e a tributação dos investimentos e da propriedade e sua interação com os demais.

Musgrave reconhece a pertinência de alguns tributos com finalidades regulatórias mais destacadas que a finalidade arrecadatória.

Da mesma forma que a sociedade pode desejar encorajar a utilização de certos recursos e prover subsídios para realiza-la, pode também desencorajar outros usos e impor penalidades para coibi-los. (...)

O economista só pode observar que ambos interferem na soberania do consumidor, porém não lhe compete dizer que tais interferências são sempre ineficientes se consideradas na estrutura mais ampla dos valores sociais. (...)

Devemos apenas observar que a utilização regulatória da tributação acarreta um custo social, sob a forma de diminuição da equidade na estrutura tributária; e devemos levar em conta este custo quando escolhermos entre impostos e outros tipos de controle. ${ }^{206}$

\footnotetext{
${ }^{204}$ Ibidem, p. 24 e 25

${ }^{205}$ Ibidem, p. 25.

${ }^{206}$ Ibidem, p. 228.
} 
Apesar de o foco de seu modelo ser a organização de um sistema fiscal ideal de bem-estar, em que a função precípua dos tributos se destina a melhor financiar os gastos orçamentários com base nas necessidades das divisões alocativa, distributiva e estabilizadora da política fiscal, buscamos analisar as funções extrafiscais da tributação e da intervenção extrafiscal regulatória do Estado, com base nos três planos finalísticos estabelecidos pelo autor.

\subsection{1 - Extrafiscalidade Alocativa}

A extrafiscalidade alocativa concerne à capacidade do Estado de intervir sobre o domínio econômico, por meio da indução tributária, com a finalidade de satisfazer necessidades coletivas por meio de bens e serviços. Trata-se da intervenção corretiva do mercado visando a garantir e estimular a produção de determinados bens e serviços e inibir o consumo de certas mercadorias.

Em síntese, é o papel econômico da tributação na alocação de recursos em determinadas atividades, em detrimento de outras, com a finalidade direta de estimulálas ou desestimulá-las.

Musgrave aborda a questão ao tratar da chamada Divisão de Alocação da Política Fiscal, que em termos mais amplos envolve também o gasto público. ${ }^{207}$ Para ele, a provisão de bens por uma economia envolve a coordenação da ação do Estado e do mercado para torná-los fruíveis. ${ }^{208}$ Nesse sentido, é qualificando os tipos de necessidades públicas que se encontrará a ação estatal mais adequada a cada caso. ${ }^{209}$

A primeira questão que se coloca é a satisfação das necessidades sociais que serão atendidas pela provisão de bens e serviços públicos. ${ }^{210}$ Aqueles cuja fruição ou consumo é não rival, indivisível, e não excluível. Exemplos deles são as ruas, a iluminação pública, a justiça e a segurança pública. ${ }^{211}$ Para teoria econômica

\footnotetext{
${ }^{207}$ Ibidem, p. 26.

${ }^{208}$ BUCHANAN, James M. e MUSGRAVE, Richard A. op. cit. p. 37.

${ }^{209}$ MUSGRAVE, Richard A. op. cit. p. 26.

${ }^{210}$ Ibidem, p. 30

${ }^{211}$ GIAMBIAGI, Fabio e ALÉM, Ana Cláudia. Finanças Públicas: Teoria e Prática no Brasil. $2^{\mathrm{a}}$ Ed. Rio de Janeiro: Elsevier, 2000, pp. 4 e 5.
} 
tradicional, a alocação de recursos para prover esses bens pelo mecanismo de preços no mercado é ineficiente e, portanto, devem os mesmos ser providos pelo Estado. ${ }^{212}$

Um segundo passo é a satisfação de necessidades meritórias que são atendidas por bens e serviços semipúblicos. ${ }^{213}$ Bens que, apesar de excluíveis, geram altos benefícios sociais e externalidades positivas que justificam sua provisão total ou parcial pelo Estado. $^{214}$ Exemplos deles são os serviços de saúde, educação, moradia e o desencorajamento da produção de bens como cigarros. ${ }^{215}$ Nesses casos, a razão para intervenção estatal não seria a ineficiência da alocação de recursos para prover esses bens pelo mecanismo de preços no mercado, mas a correção das escolhas individuais realizadas no mercado, tendo em vista o interesse coletivo.

Por fim, caberia à ação estatal a satisfação de necessidades privadas que serão atendidas por bens privados e atividade econômica. ${ }^{216}$ Bens excluíveis, divisíveis e rivais. A intervenção estatal nesses casos ocorrerá sempre que houver falhas de mercado que levem o mecanismo de preços a funcionar de forma ineficiente. Exemplos disso são externalidades, os monopólios naturais, os mercados incompletos e a assimetria de informação. ${ }^{217}$

Diante desse quadro, focando nossa análise sobre o aspecto extrafiscal da tributação, temos que ela terá distintos papéis em cada um dos tipos de situações acima elencadas.

Na provisão de bens públicos, a função alocativa da tributação é basicamente a própria finalidade fiscal dos tributos: prover o Estado de recursos para provisionar esses bens. Por se tratar de financiamento de serviço público geral e indivisível, é a hipótese típica de destinação da arrecadação de tributos não vinculados, como os impostos. No caso de bens semipúblicos e privados, no entanto, o caráter extrafiscal é mais sobressalente, pois, por meio de estímulos e desestímulos, a política fiscal buscará coordenar a ação do Estado e do mercado na provisão desses bens.

${ }^{212}$ GIAMBIAGI, Fabio e ALÉM, Ana Cláudia. op. cit., p. 12. MUSGRAVE, Richard A. op. cit., p. 27.

${ }^{213}$ MUSGRAVE, Richard A. op. cit., pp. 30-34. Ver também: GIAMBIAGI, Fabio e ALÉM, Ana Cláudia. op. cit., p. 13.

${ }_{214}^{214}$ GIAMBIAGI, Fabio e ALÉM, Ana Cláudia. op. cit., p. 13.

${ }^{215}$ MUSGRAVE, Richard A. op. cit., p. 34.

${ }^{216}$ Ibidem, p. 27/28. GIAMBIAGI, Fabio e ALÉM, Ana Cláudia. op. cit., p. 13.

${ }^{217}$ MUSGRAVE, Richard A. op. cit., p. 28. GIAMBIAGI, Fabio e ALÉM, Ana Cláudia. op. cit., pp. 7 e 8. 
No entanto, a intervenção estatal por extrafiscalidade alocativa sempre precisa ter fundamento na constituição. Isso porque, como já frisamos, a extrafiscalidade toma a forma de valores constitucionais. ${ }^{218}$

No caso brasileiro, a extrafiscalidade alocativa é a intervenção estatal sobre o domínio econômico por indução tributária, que encarna os objetivos do desenvolvimento econômico, elencado no art. $3^{\circ}$, inciso II da constituição federal. Entre eles o incentivo à cultura (art. 216, $\S 3^{\circ}$ ), ao esporte (art. 217, inciso IV e $\S 3^{\circ}$ ), à educação (art. 205), à saúde (art. 196), à ciência e tecnologia (art. 218), ao mercado interno (art. 219), ao meio ambiente ecologicamente equilibrado (art. 225) e à proteção da criança, do adolescente e do idoso (art. $227, \S 3^{\circ}$, inciso VI).

Muitos são os possíveis exemplos concretos de exercício da extrafíscalidade alocativa. Entre eles podemos citar os incentivos previstos na Lei 11.196/2005, conhecida como Lei do Bem, que estabelece, entre outros, benefícios de IRPJ, CSLL e IPI para pessoas jurídicas que realizem pesquisa tecnológica e desenvolvam inovação tecnológica.

Em direção oposta, mas no mesmo sentido, também é exemplo de extrafiscalidade alocativa a tributação de cigarros, que estabelece uma sistemática de cálculo de onde se aufere uma alíquota de $45 \%$ de IPI sobre o preço de mercado. ${ }^{219}$

Apesar de grande parte da doutrina tributária tratar as imunidades sob a perspectiva de limitação da competência tributária, enquanto normas demarcadoras de áreas de não incidência tributária, ${ }^{220}$ da perspectiva de sua finalidade, as imunidades constitucionais também podem ser compreendidas como formas de intervenção sobre o domínio econômico por indução tributária definidas na constituição.

Parte significativa delas representa verdadeiras necessidades meritórias que delimitam o campo da fiscalidade no intuito de preservar a alocação de recursos em

\footnotetext{
${ }^{218}$ GOUVÊA, Marcus de Freitas. op. cit., p. 274.

${ }^{219}$ A atual sistemática de tributação do IPI incidente sobre os cigarros, em vigor a partir de 10 de dezembro de 2011, foi instituída originalmente pelos artigos 14 a 19 da Medida Provisória no 540, de 2 de agosto de 2011, posteriormente convertida na Lei no 12.546, de 14 de dezembro de 2011, e regulamentada pelo Decreto no 7.555, de 19 de agosto de 2011. A regra geral de tributação do IPI estabelece que o mesmo será calculado utilizando-se de uma alíquota ad valorem de $300 \%$ aplicada sobre $15 \%$ do preço de venda a varejo dos cigarros, resultando em uma alíquota efetiva de $45 \%$ sobre o preço de venda a varejo dos cigarros. Disponível em:

http://www.receita.fazenda.gov.br/DestinacaoMercadorias/ProgramaNacCombCigarrollegal/TribCigarro.htm . Acesso em 17/01/2013.

${ }^{220}$ CARRAZA, Antonio Roque. Curso de Direito Constitucional Tributário. $28^{\mathrm{a}}$ ed. São Paulo: Malheiros, 2012, p. 806.
} 
determinadas atividades. São determinações constitucionais de extrafiscalidade alocativa.

São diversas as hipóteses de imunidade na constituição que constituem exemplos de extrafiscalidade alocativa. As mais célebres, no entanto, são as imunidades de impostos previstas no art. 150, inciso VI, sobre pessoas políticas, templos, partidos políticos, entidades sindicais de trabalhadores, instituições de educação, assistência social e livros. $^{221}$

Entretanto, outros exemplos também se encontram dispersos no texto constitucional, como a imunidade de contribuição para seguridade social das entidades beneficentes de assistência social, prevista no art. 195, $\S 7^{\circ}$, a imunidade de impostos das operações de transferência de imóveis desapropriados para fins de reforma agrária, prevista no art.184, $\S 5^{\circ}$, ou a imunidade de taxas para exercício do direito de petição ou obtenção de certidões para defesa de direitos, prevista no art. $5^{\circ}$, inciso XXXIV. ${ }^{222}$

\subsection{2 - Extrafiscalidade Distributiva}

A extrafiscalidade distributiva é a capacidade estatal de intervir sobre o domínio econômico, com o objetivo de redistribuir a renda, ajustando e equilibrando a apropriação do excedente entre o capital e o trabalho. Trata-se de determinar e assegurar um estado apropriado de distribuição na sociedade, por meio da tributação.

É a utilização instrumental da tributação visando ao reajuste da distribuição da renda, dando tratamento igual a pessoas que ocupem a mesma posição, independentemente de como auferem essa renda, a chamada igualdade horizontal, e dando tratamento diferente para os que ocupem posição distinta, a chamada igualdade vertical. $^{223}$

A definição deste equilíbrio é uma questão de natureza política e que a teoria das finanças públicas de Musgrave não se atreve a solucionar. O fato de reconhecer a necessidade de ajustes distributivos é importante, uma vez que alguns poderiam

${ }^{221}$ BRASIL. Constituição (1988). Constituição da República Federativa do Brasil: promulgada em 5 de outubro de 1988. Organização do texto: Juarez de Oliveira.

${ }^{222}$ Idem.

${ }^{223}$ MUSGRAVE, Richard A. op. cit, p. 43. 
considerar a distribuição ótima uma decorrência natural de uma função alocativa e estabilizadora eficiente da política fiscal.

Isso porque, ainda que a alocação de recursos seja eficiente, ela pode estar produzindo uma distribuição de renda indesejável, da perspectiva social. ${ }^{24}$ Inegavelmente, contudo, ocorre alguma sobreposição entre a extrafiscalidade alocativa e distributiva, sobretudo se atentarmos para a satisfação das chamadas necessidades meritórias, que por vezes incluem bens e serviços de caráter distributivo. ${ }^{225}$ Porém, de forma inversa, a extrafiscalidade alocativa também pode vir a representar uma piora na distribuição de riqueza do sistema, tornando-o mais regressivo, apontando para um conflito entre as duas intervenções.

A principal técnica de exercício da extrafiscalidade distributiva é a majoração de alíquotas progressivas ${ }^{226}$ e seletivas. Os efeitos redistributivos da tributação podem se dar através de uma tributação mais progressiva da renda, permitindo que posteriormente o Estado a redistribua, por meio de gastos sociais, transferência e subsídios para os cidadãos de menor renda, os valores retirados daqueles de renda mais elevada. Por outro lado, a tributação seletiva mais alta de bens de consumo supérfluo, por intermédio da aplicação de alíquotas que variem na razão inversa da essencialidade do bem, pode significar também uma forma de extrafiscalidade distributiva.

Nesse sentido, no caso brasileiro, a extrafiscalidade distributiva é a intervenção estatal sobre o domínio econômico por indução tributária que encarna os objetivos de desenvolver uma sociedade livre, justa e solidária e erradicar a pobreza e a marginalização, além de reduzir as desigualdades sociais e regionais, elencados, respectivamente, no art. $3^{\circ}$, incisos I e III, da constituição federal.

Trata-se da finalidade inscrita nos princípios constitucionais da isonomia, previsto genericamente no caput do art. $5^{\circ}$ e no art. 150, inciso II, e da capacidade contributiva, previsto no art. $145, \S 1^{\circ}$. Na redação do próprio dispositivo constitucional, todos os

${ }^{224}$ GIAMBIAGI, Fabio e ALÉM, Ana Cláudia. op. cit., p. 10.

${ }^{225}$ MUSGRAVE, Richard A. op. cit, p. 45.

${ }^{226}$ Há que se registrar, no entanto, o posicionamento sumulado do STF, ao entender inconstitucional a lei que estabeleça alíquotas progressivas de ITBI, de que a progressividade exige previsão constitucional explícita. BRASIL. Supremo Tribunal Federal. Súmula $\mathrm{n}^{\circ}$ 656. In: Vade Mecum Tributário e Financeiro. Florianópolis: Conceito, 2010. Organização do texto: João Batista Lazzari et al. 
$\operatorname{tributos}^{227}$ deverão ter caráter pessoal e graduação econômica de acordo com a capacidade do contribuinte, sempre que possível. ${ }^{228}$

Exemplos concretos de intervenção sobre o domínio econômico por extrafiscalidade distributiva é a progressividade do Imposto de Renda, prevista no art. $153 \S 2^{\circ}$, e a progressividade do IPTU em razão do valor do imóvel, prevista no art. $156, \S 1^{\mathrm{o}}$, inciso I.

A isenção de tributos federais dos produtos da cesta básica, que recentemente foi objeto de apreciação pelo congresso nacional, no bojo da Lei 12.715/2012, mas que acabou recebendo o veto presidencial, também poderia constituir um exemplo de extrafiscalidade distributiva. No mesmo sentido, caso houvesse alíquotas elevadas na tributação das heranças no Brasil, seria esse outro exemplo de extrafiscalidade distributiva. Contudo, no caso brasileiro, a Resolução do Senado Federal nº/1992 fixou em $8 \%$ a alíquota máxima de ITCMD a ser estabelecida pelos estados, o que de certa forma limita essa extrafiscalidade distributiva que em outros países chega a atingir valores bem maiores.

Além disso, o tratamento diferenciado para pequenas empresas, como o estabelecido na Lei Complementar 123 de 2006, conhecido como Simples Nacional, é também um exemplo de extrafiscalidade distributiva. Isso porque, ao estabelecer tratamento favorecido às pequenas empresas, acaba por incentivar a distribuição da acumulação de riquezas.

Quanto a imunidades que encerram extrafiscalidade distributiva, podemos citar a imunidade de ITR para pequenas glebas rurais, em que o proprietário não possui outro imóvel, prevista no art. $153, \S 4^{\circ}$, inciso II.

Como já abordamos anteriormente, ao tratarmos das formas de intervenção econômica pela tributação, a extrafiscalidade distributiva é a finalidade a que a intervenção estatal assume uma forma híbrida de indução. Caracterizada dessa forma porque não chega a ser uma intervenção compulsória por direção, forçando os agentes a realizarem os fatos geradores dos tributos. Porém, também não visa propriamente a

\footnotetext{
${ }^{227}$ Embora o texto da constituição se refira somente a impostos, o STF, ao analisar a questão decidiu que o $\S$ $1^{\circ}$ do artigo 145 estende-se a todas espécies tributárias. Vide: BRASIL. Supremo Tribunal Federal. Adin 948/GO, pleno, rel. Min. Francisco Rezek, j. 09-11-1995.

${ }^{228}$ BRASIL. Constituição (1988). Constituição da República Federativa do Brasil: promulgada em 5 de outubro de 1988. Organização do texto: Juarez de Oliveira.
} 
induzir seu comportamento, mas designar um ônus tributário maior ou menor a determinados contribuintes.

Dá-se, portanto, por meio de uma indução desvantajosa, em que o custo de se esquivar do ônus tributário imposto pela extrafiscalidade distributiva é superior ao próprio ônus tributário.

\subsection{3 - Extrafiscalidade Estabilizadora}

A extrafiscalidade estabilizadora diz respeito à capacidade de intervenção do Estado, pela tributação, em busca de manter um alto nível de utilização dos recursos e de valorização da moeda. Trata-se da utilização dos instrumentos tributários para garantir os níveis de emprego, de preços e de estabilidade macroeconômica. ${ }^{229}$

Essa função da tributação tem direta ligação com a teoria keynesiana, na qual o Estado deve se valer da política fiscal e monetária para garantir o nível de emprego na economia. ${ }^{230}$ A esse respeito, a passagem de Giambiagi é elucidativa:

\footnotetext{
A política fiscal pode se manifestar (...) indiretamente, pela redução das alíquotas de impostos, que eleva a renda disponível do setor privado. Por exemplo, em uma situação recessiva, o governo pode (...) reduzir as alíquotas de impostos, aumentando, desta forma, o multiplicador de renda da economia.

No caso da existência de um alto nível de inflação, por sua vez, decorrente de um excesso de demanda agregada na economia, o governo pode agir de forma inversa ao caso anterior, promovendo uma redução da demanda agregada, através (...) do aumento das alíquotas dos impostos - que reduziria a renda disponível e, consequentemente, o nível de consumo da economia. ${ }^{231}$
}

Pela sua própria natureza percebe-se que a extrafiscalidade estabilizadora concerne a uma finalidade indireta, que é almejada enquanto efeito no agregado da economia.

No caso brasileiro, a extrafiscalidade estabilizadora é a intervenção estatal sobre o domínio econômico por indução tributária, que encarna os princípios gerais da atividade econômica elencados no art. 170, incisos I, IV, V e VIII, da constituição

\footnotetext{
${ }^{229}$ MUSGRAVE, Richard A. op. cit, p. 46.

${ }^{230}$ BUCHANAN, James M. e MUSGRAVE, Richard A. op. cit.,pp.48 e 49.

${ }^{231}$ GIAMBIAGI, Fabio e ALÉM, Ana Cláudia. op. cit., p. 15.
} 
federal. Ou seja, respectivamente: a soberania nacional, a livre concorrência, a defesa do consumidor e a busca do pleno emprego.

É o caso, por exemplo, da redução de IPI e IOF promovida pelos decretos 7.725/2012 e 7726/2012, para a compra de automóveis, concedidas como forma de combate à crise econômica. Embora tenham impacto direto na alocação de recursos, incentivando a produção de automóveis, os efeitos buscados são: manter o nível de emprego da economia e não privilegiar o transporte individual, muito embora acabe por fazê-lo.

É garantia do exercício da extrafiscalidade estabilizadora a possibilidade de a União alterar as alíquotas dos impostos de importação e de exportação sem observar os princípios da legalidade e da anterioridade que regem o regime jurídico da grande maioria dos tributos. Essa faculdade, prevista no art. $150, \S 1^{\circ}$, da CF, cria condições para que a União proteja o equilíbrio da balança comercial brasileira, atuando diretamente sobre a estabilidade macroeconômica do país.

Na mesma trilha, a faculdade da União de majorar ou minorar as alíquotas de IOF, também excetuada pelo art. $150, \S 1^{\circ}$, da CF, de observar os princípios da legalidade e anterioridade, responde a essa mesma capacidade de intervenção sobre o domínio econômico por extrafiscalidade estabilizadora. Trata-se de poder intervir sobre a circulação financeira de investimentos, inibindo-a ou incentivando-a de forma a garantir a estabilidade macroeconômica brasileira.

Algumas imunidades também podem ser compreendidas como formas de intervenção por extrafiscalidade estabilizadora. É exemplo a imunidade do ouro quando ativo financeiro ou instrumento cambial, que somente admite a incidência de IOF e não de ICMS, por definição do art. $153, \S 5^{\circ}$, e do art. $155, \S 2^{\circ}$, inciso X, alínea "c". Assim como a imunidade de ITBI em operações de realização de capital ou de incorporação, fusão, cisão ou extinção de pessoa jurídica, prevista no art.156, $\S 2^{\circ}$, inciso I. É, também, a extrafiscalidade estabilizadora que se encerra na imunidade de IPI e ICMS para produtos destinados à exportação, prevista, respectivamente, no art. $153, \S 3^{\circ}$, inciso III, e no art. $155, \S 2^{\circ}$, inciso X, alínea "a".

Quanto ao ICMS, aliás, uma série de imunidades específicas foram sendo introduzidas como forma de harmonizar os efeitos indiretos decorrentes de sua 
cobrança. É o caso da imunidade sobre operações que destinem petróleo, derivados ou energia elétrica para outros Estados (art. 155, $\S 2^{\circ}$, inciso X, alínea “b”).

Além desses exemplos acima elencados, compõe a extrafiscalidade estabilizadora o exercício das competências excepcionais federativas com o intuito de estabilizar as repercussões econômicas de tributos estaduais ou municipais. Exemplificativamente, é o caso das limitações ao poder de tributar dos estados e do Distrito Federal na instituição de seus impostos, como nas hipóteses de definição de alíquotas por resolução do Senado Federal (art. 155, $\S 1^{\circ}$, inciso IV; art. 155, $\S 2^{\circ}$, incisos IV e V; art. $155, \S 6^{\circ}$, inciso I) ou na previsão de lei complementar para regular diversas nuances da cobrança de ICMS, como a forma de deliberação sobre isenções e benefícios fiscais (art. 155, $\S 2^{\circ}$, inciso XII). Também é o caso da previsão de lei complementar para regular a cobrança municipal do ISSQN.

Trata-se de mecanismos para se evitar que eventuais efeitos macroeconômicos decorrentes de uma ação descoordenada dos estados ou municípios, em vista de seus interesses fiscais ou extrafiscais particulares, gere efeitos indesejáveis ao conjunto da economia brasileira nacional. A esse respeito, assevera o próprio Musgrave, ao tratar de governos federativos:

\begin{abstract}
O cerne do federalismo fiscal repousa, assim, na proposição de que as políticas da Divisão de Alocação devem ter permissão para diferir entre os Estados, dependendo sempre das preferências de seus cidadãos. Os objetivos das Divisões de Distribuição e de Estabilização requerem, entretanto, que a responsabilidade maior recaia sobre o governo central. ${ }^{232}$
\end{abstract}

Percebe-se, que sob ângulo da racionalidade econômica, a coordenação da política fiscal é um imperativo que tende, invariavelmente, à centralização da função estabilizadora e também da função distributiva.

${ }^{232}$ MUSGRAVE, Richard A. op. cit, p. 231 e 232. Ver também: BUCHANAN, James M. e MUSGRAVE, Richard A. op. cit.,pp.162-175. 


\section{4 - Competências para Tributar e Capacidade de \\ Intervenção Extrafiscal}

Geraldo Ataliba foi um dos primeiros doutrinadores a chamar a atenção para o fato de que uma das principais características do sistema tributário brasileiro reside em sua constitucionalização. ${ }^{233}$

Diferentemente do que ocorre na maioria dos sistemas latino-americanos e europeus, a ordem tributária brasileira está contida em detalhes na constituição federal e suas lacunas são por ela expressamente reservadas à figura da lei complementar. ${ }^{234} \mathrm{~A}$ rigidez é a marca do sistema tributário brasileiro, sendo muito restrita a possibilidade de alterações por meio de legislação ordinária, ou mesmo de atos administrativos e decretos do poder executivo. ${ }^{235}$

Em certa medida, essa constitucionalização do sistema tributário é um traço presente nas constituições brasileiras desde 1891, porém, não resta dúvida de que o processo de constitucionalização do sistema foi se ampliando progressivamente até 1988.

34 - Quer isto dizer que, em contraste com os sistemas constitucionais tributários francês, italiano ou norte-americano, por exemplo, o constituinte brasileiro esgotou a disciplina da matéria tributária, deixando à lei, simplesmente, a função de regulamentar. Nenhum arbítrio e limitadíssima esfera de discrição foi outorgada ao legislador ordinário. ${ }^{236}$

Essa característica impõe limitações ao exercício do poder de tributar e, consequentemente, também à capacidade regulatória do Estado pela tributação.

Embora esses limites envolvam também garantias dos contribuintes alçadas à condição de princípios constitucionais, como as zonas de não tributação - no caso das imunidades - ou como a necessária adoção de procedimentos formais para que se possa

\footnotetext{
${ }^{233}$ ATALIBA, Geraldo. Sistema Constitucional Tributário Brasileiro. São Paulo: Revista dos Tribunais: 1968.

${ }^{234}$ A esse respeito, lembra Marçal Justen que mesmo as constituições portuguesas e espanholas - que são mais recentes e de perfil mais detalhista - não se aproximam de consagrar tantos dispositivos como a constituição brasileira. JUSTEN FILHO, Marçal. Sistema Constitucional Tributário: Uma Aproximação Ideológica. Curitiba. Revista da Faculdade de Direito da UFPR. Ano 30. N 30, 1998, p. 217.

${ }^{235}$ Ibidem.

${ }^{236}$ ATALIBA, Geraldo. op. cit.1968, p. 18
} 
tributar - no caso da observância da anterioridade da lei e da estrita legalidade tributária - eles também demarcam a repartição de competências tributárias essencial à estrutura federal.

A capacidade de indução extrafiscal de União, Estados, Distrito Federal e Municípios sempre foi vista pela dogmática tributária como a outra face da repartição de suas competências tributárias fiscais. Como argumenta Roque Antonio Carraza, quem pode tributar pode também aumentar sua alíquota, minorá-la, parcelar seu pagamento, isentá-lo, remi-lo, anistiar as infrações fiscais ou mesmo não tributá-lo. ${ }^{237}$

A esse respeito, o entendimento de Geraldo Ataliba sobre a lógica do sistema tributário brasileiro na constituição de 1946 era o seguinte:

\begin{abstract}
Deve-se entender que a rigidez referida é tão sòmente jurídica. Vinculado aos padrões hirtos da Constituição está o legislador ordinário, só juridicamente. Sob a perspectiva econômica, entretanto, a mais ampla liberdade é conferida ao legislador ordinário, para atualizar-se com as conquistas da ciência econômica e acompanhar o progresso das especulações financeiras, adaptando-se às

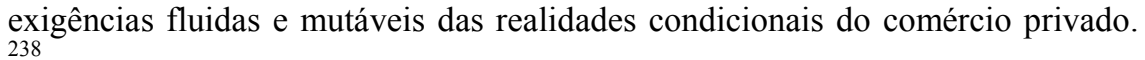

A rigidez jurídica das competências tributárias brasileiras se contrastaria com a flexibilidade econômica do sistema que, a seu ver, concedia ampla capacidade de modificação pela pessoa política competente. ${ }^{239}$ Incorporados os preceitos básicos dos impostos ali determinados, sua regulamentação seria praticamente livre. O que de certa forma apontaria que a tradição constitucional brasileira vislumbrava a utilização extrafiscal dos tributos como decorrência direta de sua competência fiscal.

Em posição isolada, Theotônio Monteiro de Barros argumentava que o regime jurídico das taxas, relativas aos serviços públicos em que a finalidade fiscal é secundária, não poderiam ser os mesmos das relativas a serviços de finalidade físcal exclusiva. $^{240}$

Geraldo Ataliba, em linha oposta, dizia que apesar de lícita a utilização extrafiscal da tributação, ela seria apenas uma peculiaridade interpretativa que não autorizava sua

${ }^{237}$ CARRAZA, Antonio Roque. op. cit., p.569.

${ }^{238}$ ATALIBA, Geraldo. op. cit.1968, p. 38.

${ }^{239}$ Ibidem, p. 30.

${ }^{240}$ MONTEIRO DE BARROS, Theotônio M. B. Filho. As taxas e seus problemas teóricos. São Paulo: Revista dos Tribunais, 1941, p. 78. Apud em: ATALIBA, Geraldo. op. cit.1968, p. 156. 
não submissão ao mesmo regime imposto aos tributos. ${ }^{241}$ Qualquer entendimento diverso seria franquear ao legislador um arbítrio ilimitado. ${ }^{242}$

\begin{abstract}
(...) lembramos somente que hoje não há tributo que, de certa forma, não se preste a alguma finalidade extrafiscal. Na verdade não é mais possível discernir, principalmente quanto aos impostos, até onde e quando vão os institutos fiscais e até onde os ordinatórios, do legislador. (...)

Isto considerado, vê-se quão perigosa e irreal é a tese da insubmissão da extrafiscalidade ao regime tributário. (...) Diante da resistência do contribuinte a qualquer exigência tributária inconstitucional, responderia o fisco que se trata de tributação extrafiscal. ${ }^{243}$
\end{abstract}

Nesse sentido, não haveria nenhuma diferença jurídica entre os tributos fiscais e os extrafiscais, cabendo ao direito tributário apenas oferecer ao legislador tábua especificada de instrumentos jurídico-tributários, na qual aquele político possa escolher os elementos que bem lhe convenham para o bom resultado de sua função regulatória. $^{244}$

Assim sendo, parece claro que, para uma boa parte da doutrina tributária, a capacidade de exercício da extrafiscalidade se confunde com as competências para instituir e cobrar tributos. Seriam as competências tributárias, outorgadas pela constituição a cada ente, na forma ali indicada, que melhor definiriam o escopo de seu potencial de intervenção extrafiscal.

Portanto, da repartição constitucional das competências tributárias se teria a capacidade de intervenção extrafiscal das pessoas políticas. Isso porque a tônica do federalismo fiscal brasileiro foi a repartição de competências exclusivas entre as pessoas políticas. ${ }^{245} \mathrm{Ou}$ seja, os tributos que competem a uma pessoa política instituir, não competem às demais.

Assumindo esse quadro, é na repartição dos tributos elencada a partir do artigo 145 da constituição de 1988 que se podem observar as competências tributárias e extrafiscais da União, dos Estados, do Distrito Federal e dos Municípios.

\footnotetext{
${ }^{241}$ ATALIBA, Geraldo. op. cit.1968, p. 156.

242 Idem.

${ }^{243}$ Idem.

${ }^{244}$ CARVALHO, Paulo de Barros. op. cit. 1976, pp. 32-38.

${ }^{245}$ A esse respeito observava Geraldo Ataliba: "A regra geral no direito constitucional tributário brasileiro, em matéria de impostos, é a privatividade - ou exclusividade - da competência das pessoas políticas, para instituí-los e arrecadá-los.” In: ATALIBA, Geraldo. op. cit.1968, p. 210. Ver também: CARRAZA, Antonio Roque. op. cit., p. 584.
} 
As únicas espécies tributárias que são comuns a União, Estados, Distrito Federal e Municípios são as taxas - exigidas pelo exercício do poder de polícia ou pela utilização de serviços públicos específicos e divisíveis - e as contribuições de melhoria, decorrentes de obras públicas. ${ }^{246}$

Disso decorre que no exercício da capacidade tributária relativa a esses tributos, do ponto de vista da competência federativa, os entes federados terão ampla liberdade para exercerem o poder de indução extrafiscal. Entretanto, sua instituição é vinculada a uma contraprestação e não pode coincidir com fatos geradores de impostos. ${ }^{247}$

À União é reservado um poder mais amplo de indução extrafiscal. Os impostos sob sua tutela incluem o ITR, IOF, IR, IE, II e IPI. Além disso, ela possui competência para instituir impostos não previstos na constituição, desde que não cumulativos e com fatos geradores e base de cálculo distintos dos já existentes, bem como impostos extraordinários no caso de guerra. ${ }^{248}$ Some-se a isso a faculdade de instituir o IGF que, embora previsto na constituição, nunca foi regulamentado.

Também compete apenas à União a capacidade de instituir empréstimos compulsórios, contribuições de intervenção no domínio econômico e contribuições sociais e de interesse de categorias profissionais ou econômicas. ${ }^{249}$ As exceções a esse quadro, de contribuições de competência de estados e municípios, são expressas na própria constituição. ${ }^{250}$

Aos Estados, a competência para instituir impostos fica adstrita ao ICMS, ao IPVA e ao ITCMD. ${ }^{251}$

Aos Municípios a competência para instituir o IPTU, ITBI e ISS. ${ }^{252}$ Ao Distrito Federal cabem tanto as competências dos Estados quanto as dos Municípios. ${ }^{253}$

Todavia, algumas objeções merecem ser colocadas a essa interpretação. Não porque as limitações ao poder de tributar não se apliquem à capacidade de intervenção no domínio econômico pela tributação, excetuando seu regime jurídico em função de sua

\footnotetext{
${ }^{246}$ BRASIL. Constituição (1988). Constituição da República Federativa do Brasil: promulgada em 5 de outubro de 1988. Organização do texto: Juarez de Oliveira, art. 145.

${ }^{247}$ Idem, art. 145, Caput e $\S 2^{\circ}$.

${ }^{248}$ Idem, arts. 153 e 154.

${ }^{249}$ Idem, arts. 148 e 149.

${ }^{250}$ Frise-se, no entanto, que não são poucas.

${ }^{251}$ Idem, art. 155 .

252 Idem, art. 156.

${ }^{253}$ Idem, art. 147.
} 
finalidade, como temiam muitos doutrinadores, ${ }^{254}$ mas porque as limitações constitucionais ao poder regulatório do Estado também se aplicam a ela.

Nesse sentido, sobre a tributação extrafiscal incidem as limitações e regramentos decorrentes tanto de seu instrumento, o regime jurídico tributário, quanto de sua finalidade, a intervenção indutora sobre o espaço econômico com intuito alocativo, distributivo ou estabilizador.

A capacidade de intervenção extrafiscal dos tributos, se tomada como discricionária da pessoa política competente para instituir os tributos, ignora que a constituição estabeleceu limites, finalidades, objetivos e formas para qualquer intervenção econômica do Estado brasileiro e expressamente sobre a intervenção econômica por meio de alguns impostos.

Como poderia, por exemplo, que um município ou estado instituísse discricionariamente benefícios fiscais de ISS ou ICMS, se a constituição prevê que a forma e as condições para a concessão dos mesmos deverá ser estabelecida por lei complementar (art. 156, $\S 3^{\circ}$, inciso III e art. 155, $\S 2^{\circ}$, inciso XII, alínea “g”) e as respectivas leis estão vigentes (Lei Complementar 116/2003 e Lei Complementar 24/1975)?

Seria discricionário à União, estados e municípios intervir sobre o espaço econômico por indução tributária sem observar os princípios em que se fundam a ordem econômica brasileira, estabelecidos no art. 170 da CF? Reduzindo progressivamente, por exemplo, a alíquota de IPTU da propriedade improdutiva ao longo do tempo, em franca contraposição aos art. 170, inciso III e art. 182, $\S 4^{\circ}$, inciso II?

A própria jurisprudência do Supremo Tribunal Federal é alvo de preocupação, na medida em se esquiva, assim como a doutrina tributária, de analisar tais repercussões. Ao mesmo tempo em que o STF reconhece a validade da distinção e da utilização da tributação com finalidades extrafiscais, não costuma considerar se os reflexos que esta utilização gerará sobre a economia se chocam com os princípios da ordem econômica estabelecidos na constituição. $^{255}$

\footnotetext{
${ }^{254}$ Entre eles Geraldo Ataliba. Vide: ATALIBA, Geraldo. op. cit.1968.

${ }^{255}$ Gustavo do Amaral Martins aponta alguns julgados exemplificativos desta postura, como o RE n ${ }^{\circ} 158.834$ e a ADI no 3.401. Para maiores detalhes ver: AMARAL MARTINS, Gustavo do. op. cit., p. 138 e 139.
} 
A quantidade de julgados pelo Supremo Tribunal Federal é diminuta no que se refere ao controle do exercício da extrafiscalidade. Na década de 1990, a Corte evitou o tema, afirmando serem atos discricionários do Poder Público, embora reconhecesse a necessidade de motivação constitucionalmente legítima. ${ }^{256}$ Mais recentemente, pronunciou-se sobre o tema, reconhecendo a dimensão extrafiscal inibidora da tributação no caso do aumento de IPI dos cigarros, e avalizando os fins empregados para ela no caso. ${ }^{257}$

Mas ainda que nos restrinjamos ao debate formal sobre competências, a competência para intervir sobre o espaço econômico enquanto regulador não condiz, necessariamente, com as competências tributárias estabelecidas pela constituição. Exemplo claro disso é o fato de o artigo 22, inciso VIII, da CF, estabelecer a competência privativa da União para legislar sobre o comércio exterior e interestadual a despeito de o ICMS, imposto estadual, incidir sobre a circulação de mercadorias importadas, exportadas ${ }^{258}$ e destinadas a outros estados.

Poderiam os estados regular o comércio exterior e interestadual por meio de incentivos de ICMS, sem invadir a competência legislativa privativa da União de regular o tema?

Luís Eduardo Schoueri remonta esse debate na doutrina tributária brasileira demonstrando que, apesar de inconclusivo, muitos entendem ser necessária a cumulação da competência tributária com a competência reguladora do tema para que se possa intervir por indução tributária no domínio econômico. Entre eles, Ricardo Lobo Torres, Sampaio Dória, Ruy Barbosa Nogueira e Alcides Jorge da Costa. ${ }^{259}$ Levando-o a concluir que:

(...) as normas tributárias indutoras são reflexo do poder de regular, não do poder de tributar (...).

\footnotetext{
${ }^{256} \mathrm{Na}$ análise do Recurso Extraordinário n. ${ }^{\circ}$ 149.659, julgado em 1995, o tribunal entendeu que a isenção "decorre do implemento de política fiscal e econômica, pelo Estado, tendo em vista determinado interesse social; envolve, assim, um juízo de conveniência e oportunidade do Poder Executivo", não estando sujeita a controle material pelo Poder Judiciário. Para maiores detalhes ver: ASSUNÇÃO, Matheus Carneiro. Incentivos Fiscais e Desenvolvimento Econômico: a função das normas tributárias indutoras em tempos de crise. Finanças Públicas - XV Prêmio Tesouro Nacional. 2010, pp. 24 e 25.

${ }^{257} \mathrm{Idem}$.

${ }^{258}$ Muito embora a emenda constitucional 42/2003 tenha criado imunidade de ICMS par produtos destinado à exportação.

${ }^{259}$ SHOUERI, Luís Eduardo. op. cit., pp. 347-349.
} 
Assim é que as normas tributárias indutoras sujeitam-se: I) por força do veículo pelo qual se introduzem no mundo jurídico, às regras de repartição de competências tributárias; II) por força da matéria que regulam, às regras de competência legislativa. Conclui-se, portanto, pela necessária concomitância de competências, para que se introduzam normas tributárias indutoras no ordenamento brasileiro. ${ }^{260}$

A capacidade de intervenção extrafiscal das pessoas políticas, portanto, se equilibraria entre o exercício privativo de suas competências tributárias, outorgadas pela constituição, e pelos limites a esse exercício estabelecidos pela constituição de forma explícita ao tratar de seus tributos; pela repartição federativa das competências legislativas, também estabelecida pela constituição; e pelas leis complementares e normas gerais, federais ou estaduais, que versem sobre o direito tributário, financeiro ou econômico.

A sequência de questões que se colocam para análise jurídica da competência para uma intervenção do Estado na economia por indução tributária é:

a) A pessoa política interventora é competente para exigir tais tributos?

b) A pessoa política interventora realiza essa intervenção observando todos os limites ao poder de tributar estabelecidos pela constituição?

c) A pessoa política interventora tem competência para utilizar essas técnicas de intervenção?

d) A pessoa política interventora tem competência para legislar sobre a matéria a qual visa regular por meio da indução tributária?

${ }^{260}$ Ibidem, p. 351. 


\section{ESTRUTURA JURÍDICA DO SISTEMA TRIBUTÁRIO NACIONAL}

A compreensão da intervenção econômica do Estado pela tributação, no entanto, passa pelo conhecimento da evolução da ordenação constitucional tributária brasileira. É ela que delimita, constrange e formata o sistema e, consequentemente, as políticas extrafiscais. O histórico de suas transformações, reformas e mutações revela as tensões políticas e institucionais que construíram os limites e as possibilidades do exercício do poder extrafiscal no Brasil.

Além disso, a utilização do ferramental analítico do direito econômico para a intervenção extrafiscal do Estado sobre o domínio econômico só pode ocorrer se aplicada a uma experiência concreta. Enseja, assim, uma análise da evolução histórica brasileira das competências tributárias e da capacidade extrafiscal das pessoas políticas de nosso federalismo.

A abordagem histórica nos permite articular os atores relevantes no sistema e os instrumentos jurídicos disponíveis para a consecução de seus objetivos. Pelo manuseio dos textos normativos, com seus objetivos constitucionalmente determinados, também nos permite apontar as possibilidades do sistema estruturado dogmaticamente em face de suas condicionantes históricas. ${ }^{261}$

Por essa razão que nossa opção foi por estabelecer uma narrativa das principais questões que envolvem as dificuldades e possibilidades da utilização da indução extrafiscal por parte das pessoas políticas do federalismo brasileiro, em vez de enveredar por uma análise da extrafiscalidade em cada um dos institutos do direito tributário.

Nesse sentido, a abordagem adotada neste capítulo, para expor as transformações de competência e incidência do sistema tributário brasileiro, se desenvolve enquanto a análise histórico-institucional da dinâmica desses conflitos: o pacto federativo físcal e as fontes de arrecadação tributária, principalmente dos impostos. É pela compreensão

${ }^{261}$ BERCOVICI, Gilberto. op. cit. 2011, p. 13. 
de ambas as tensões que poderemos vislumbrar o sistema tributário enquanto um instrumento da ação indutora do Estado na economia. 


\section{1 - Sistemas Tributários Autônomos e Independentes}

Apesar das grandes transformações pelas quais passou a economia brasileira no longo período que se estende entre a constituinte de 1890 e o golpe militar de 1964, a principal tensão política que motivou as várias mudanças tributárias nesse período foi a necessidade de receitas. A preocupação com a isonomia do sistema ou com a repercussão econômica da tributação esteve presente, progressivamente, mas ainda de forma secundária.

Ao longo do tempo essa busca pela arrecadação tributária se traduziu em dois conflitos permanentes: a disputa entre estados, União e municípios na repartição federativa das receitas e a definição da fonte principal da tributação, a atividade econômica sobre a qual recairia o encargo de ser a financiadora do Estado.

A resultante dessas tensões acabou por definir uma série de características que foram se desenvolvendo ao longo deste período, muitas das quais viriam a ser consolidadas na década de 1960 e repactuadas em 1988.

São exemplos disso: o sistema de repartição da arrecadação de impostos entre os entes da federação e a definição da tributação indireta como a fonte por excelência da arrecadação estatal - primeiramente sobre o comércio exterior e posteriormente sobre as bases domésticas.

Mas o traço principal que marca este período da tributação brasileira reside na constituição de esferas autônomas de competência tributária e sistemas estaduais, municipais e federal, independentes entre si. Apesar de algumas inovações no sentido de coordenação e racionalização desses sistemas surgirem a partir dos anos 1930, sua característica principal é a autonomia econômica e jurídica das pessoas políticas de nosso federalismo.

\subsection{1 - Evolução das Fontes de Financiamento Tributário}

A configuração do sistema tributário brasileiro enquanto instrumento de política econômica era embrionária até as reformas implantadas durante o regime militar. No 
Império, não havia uma sistematização própria dos tributos ou mesmo um sistema tributário articulado. A principal distinção que se consagrava era entre contribuições directas, cobradas nominalmente sobre o patrimônio, a renda e a propriedade das pessoas, e contribuições indirectas, cobradas sobre gêneros e mercadorias de consumo. Sua principal fonte de tributação era o comércio exterior. ${ }^{262}$

Da perspectiva das fontes tributárias, até a industrialização no início da década de 1930, o sistema era praticamente o mesmo que vigorara no Império e cuja consolidação se deu, por mais irônico que possa parecer, com a constituição republicana de 1891 .

É ainda durante a ordem econômica liberal da constituição de 1891 que começam a se desenhar os impostos sobre o consumo e sobre a renda. O primeiro surge como evolução da tributação sobre o fumo, criado pela Lei $\mathrm{n}^{0} 25$, de 03 de dezembro de 1891, que posteriormente passa a abarcar outros produtos como o sal, vinagre, calçados, bebidas, velas etc. Somente em 1922 é criado o imposto sobre as vendas mercantis que passaria para competência dos estados. ${ }^{263}$ Já a cobrança de um imposto geral sobre a renda somente passou a ser cobrado em 1924, por meio da Lei ${ }^{0} 4.783$ de 31 de dezembro de 1923.

O imposto sobre as importações permanecia como a principal fonte de arrecadação da União, quadro que só se alterou durante a primeira guerra mundial e a consequente redução do comércio exterior. No mesmo sentido, a principal fonte de financiamento dos Estados era o imposto sobre as exportações, que respondia por cerca de $40 \%$ dos recursos de seus governos. ${ }^{264}$

É após a crise de 1929 que as mudanças começam a ganhar corpo, de fato, na estrutura tributária do país. Pressionado pela necessidade de transitar de um modelo econômico apoiado no complexo cafeeiro-exportador, o governo se vê impelido a fortalecer o papel regulador e intervencionista do Estado. Esse novo padrão de acumulação nacional que se inicia passa a exigir fontes endógenas de arrecadação tributária que permitam realizar os investimentos necessários. $^{265}$

${ }^{262}$ ATALIBA, Geraldo. Sistema Constitucional Tributário Brasileiro. São Paulo: Revista dos Tribunais: 1968, p. 48.

${ }^{263}$ VARSANO, Ricardo. A Evolução do Sistema Tributário ao Longo do Século: Anotações e Reflexões para Futuras Reformas. Rio de Janeiro: Texto para Discussão nº 405 IPEA, 1996, p. 2.

${ }^{264}$ Ibidem, p. 3

${ }^{265}$ OLIVEIRA, Fabrício Augusto de. A Reforma Tributária de 1966 e a Acumulação de Capital no Brasil. 2a ed. Belo Horizonte: Oficina de Livros, 1991, p. 23. 
Assim, a constituição de 1934 trouxe relevantes inovações para o sistema dotando-o de condições para ingressar numa etapa mais complexa em que predominariam os impostos internos sobre os produtos. ${ }^{266}$

Entretanto, é apenas a partir de 1937 que esse quadro se inverte e as inovações da constituição passam a ter repercussão econômica. Isso porque é nesse período que o adensamento urbano torna-se suficiente para que os tributos internos possam efetivamente dar um salto de arrecadação. ${ }^{267}$

Progressivamente as bases domésticas de tributação se tornaram as principais receitas que compunham o fundo público nacional. $\mathrm{O}$ imposto de vendas $\mathrm{e}$ consignações, por exemplo, correspondia a cerca de $45 \%$ de toda a arrecadação estadual no início dos anos 40, parcela esta que se elevaria para 60\% nos 20 anos seguintes, na medida em que a relevância do imposto sobre as exportações cai para cerca de $10 \%{ }^{268} \mathrm{O}$ gráfico abaixo passa uma boa ideia das mudanças no perfil da arrecadação brasileira no período:

${ }^{266}$ VARSANO, Ricardo, op. cit., p. 3.

${ }^{267}$ OLIVEIRA, Fabrício Augusto de, op. cit., p. 24.

${ }^{268}$ Idem. 


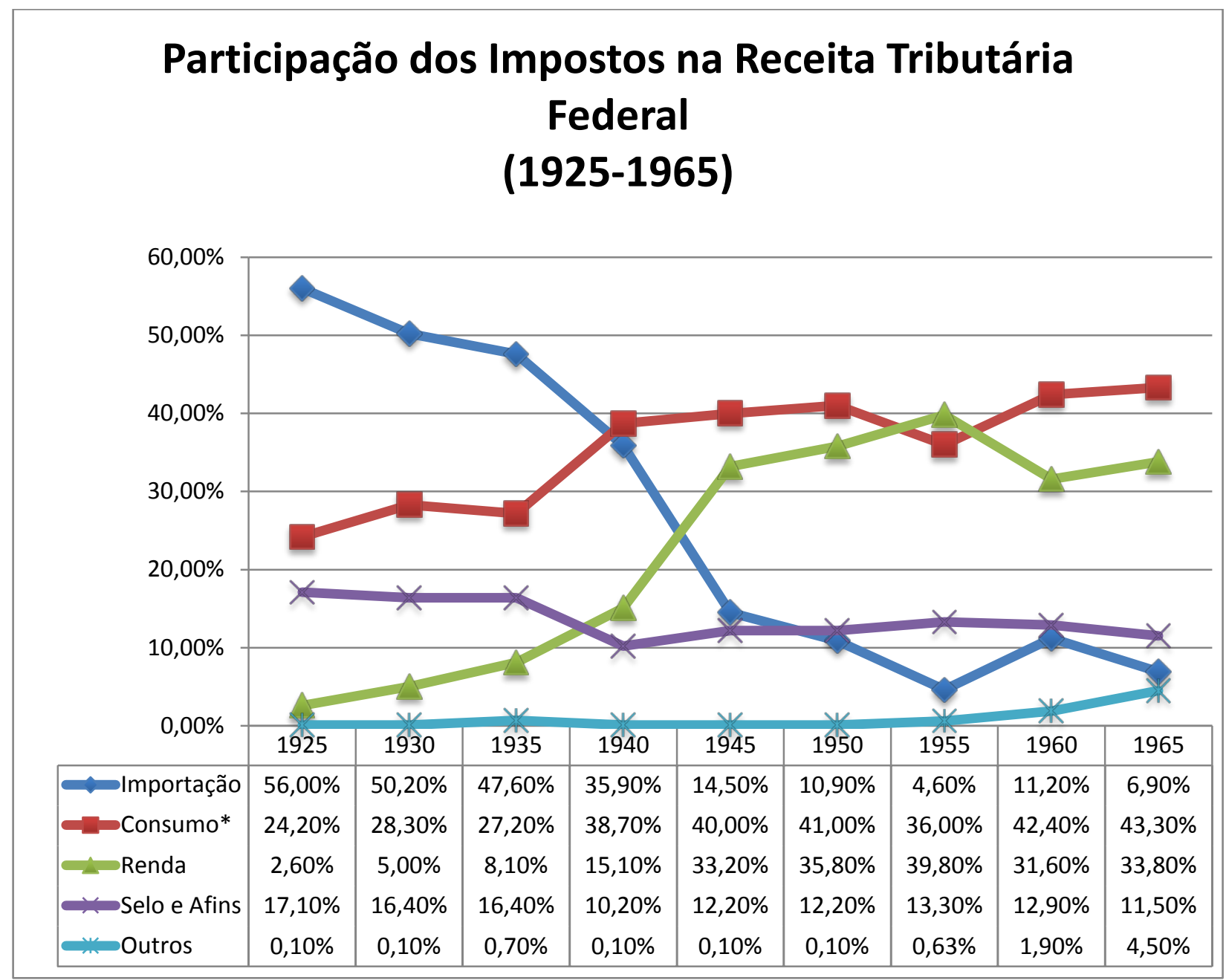

* Imposto incidente sobre produtos industrializados

Fonte: OLIVEIRA, Fabrício Augusto de. A Reforma Tributária de 1966 e a Acumulação de Capital no Brasil. 2a ed. Belo Horizonte: Oficina de Livros, 1991, p. 21, 25 e 33.

A reforma de fundo da legislação tributária brasileira se tornava urgente diante do esforço industrializante e pela crescente participação estatal no processo de acumulação, intensificado no país a partir dos anos 1950, especialmente diante da ausência de uma estrutura econômica forte o bastante para dar suporte a esse processo. $^{269} \mathrm{O}$ elevado aumento das despesas governamentais, gerado com a industrialização, não podia ser acompanhado pelas receitas provenientes de uma estrutura tributária herdada do Império. ${ }^{270}$

\footnotetext{
${ }^{269}$ Ibidem, p. 27. Ver também: VARSANO, Ricardo. A Evolução do Sistema Tributário ao Longo do Século: Anotações e Reflexões para Futuras Reformas. Rio de Janeiro: Texto para Discussão n ${ }^{\circ} 405$ IPEA, 1996, p. 6.

${ }^{270}$ Idem.
} 
Por essa razão que já em 1951 cria-se o adicional restituível sobre o IR, por meio da Lei $\mathrm{n}^{0} 1.474$, de 26 de novembro de 1951, cuja arrecadação seria destinada para o Fundo de Reaparelhamento Econômico, o qual empregaria recursos para a criação do BNDE em 1952. ${ }^{271}$

No mesmo sentido, é com vistas à ampliação da oferta energética que se cria, por meio da Lei $\mathrm{n}^{0}$ 2.308, de 31 de agosto de 1954, o imposto único sobre a energia elétrica, cujos recursos seriam destinados ao Fundo Federal de Eletrificação. ${ }^{272}$

Entretanto, mesmo que os esforços lançados no período tenham levado o modelo ao limite da arrecadação, ainda não podiam fazer frente às necessidades de investimentos que lhe eram exigidas. Além disso, as inúmeras distorções geradas pelo sistema dificultavam a condução de uma política econômica industrializante.

O que emerge deste quadro é que, de certa maneira, as mudanças ocorridas no sistema tributário brasileiro entre 1891 e 1965 são reflexos das transformações de uma economia totalmente agroexportadora em uma economia parcialmente industrial e voltada para o mercado interno. Essa migração, no entanto, no plano da tributação, é ainda conjuntural e pouco planejada, sendo insuficiente para dotar o sistema de instrumentos eficazes para realização de uma política econômica tributária organizada e coesa.

\subsection{2 - Evolução do Federalismo Fiscal}

A falta de consenso na divisão de recursos entre o poder central e o poder regional já se fazia sentir desde a constituinte de 1890. Nesse período, o principal embate se travou em torno da proposta de Julio de Castilhos, que pretendia discriminar a receita da União, reduzindo-a a quatro tributos, resguardando as fontes remanescentes à competência privativa dos Estados. ${ }^{273}$

\footnotetext{
${ }^{271}$ Ibidem, p. 27.

${ }^{272}$ Idem.

${ }^{273}$ LEAL, Victor Nunes. Coronelismo, Enxada e Voto: O Município e o Regime Representativo no Brasil. $7^{\mathrm{a}}$ ed. São Paulo: Companhia das Letras 2012, p. 148.
} 
Atribui-se a Rui Barbosa papel decisivo para derrota da proposta e a vitória do projeto do governo provisório, sob as alegações de que a tarefa imediata da constituinte era garantir a independência da União. ${ }^{274}$

Dessa maneira, saiu vitorioso o modelo em que se discriminavam os principais impostos de competência exclusiva da União e dos Estados, ${ }^{275}$ muito embora não se estabelecesse um rol taxativo dos tributos, na medida em que não se vedava a possibilidade deles instituírem novas espécies tributárias. ${ }^{276}$

À União foi reservada a competência para tributar as importações, os direitos de entrada, saída e estadia de navios, taxas de selo e taxas de correios e telégrafos federais. ${ }^{277}$ Aos Estados foi assegurada competência para decretar impostos sobre a exportação de mercadorias, sobre imóveis rurais e urbanos, transmissão de propriedades, profissões e indústrias, bem como taxas de selo e contribuições sobre seus correios e telégrafos. ${ }^{278}$ Quanto aos Municípios, a Constituição optou por não dispor sobre suas fontes tributárias, incumbindo aos Estados o dever de garantir-lhes a autonomia financeira. ${ }^{279}$

A evolução dessa repartição das receitas tributárias viria a consolidar o seguinte quadro na constituinte de 1933-34:

\footnotetext{
${ }^{274}$ Idem.

${ }^{275}$ VARSANO, Ricardo, op. cit. p. 2. Isso, pois, não havia uma preocupação sistemática de prever todas as espécies tributárias no texto constitucional, mas sim pactuar a repartição das principais fontes de receita. Algumas espécies de menor significância em termos de volume de arrecadação, como, por exemplo, o caso de impostos sobre os vencimentos e benefícios distribuídos por sociedades anônimas, não foram discriminadas na constituição.

${ }^{276}$ Artigo $12^{\circ}$ da Constituição de 1891.

${ }^{277}$ Artigo $7^{\circ}$ da Constituição de 1891.

${ }^{278}$ Artigo $9^{\circ}$ da Constituição de 1891.

${ }^{279}$ Artigo $68^{\circ}$ da Constituição de 1891.
} 


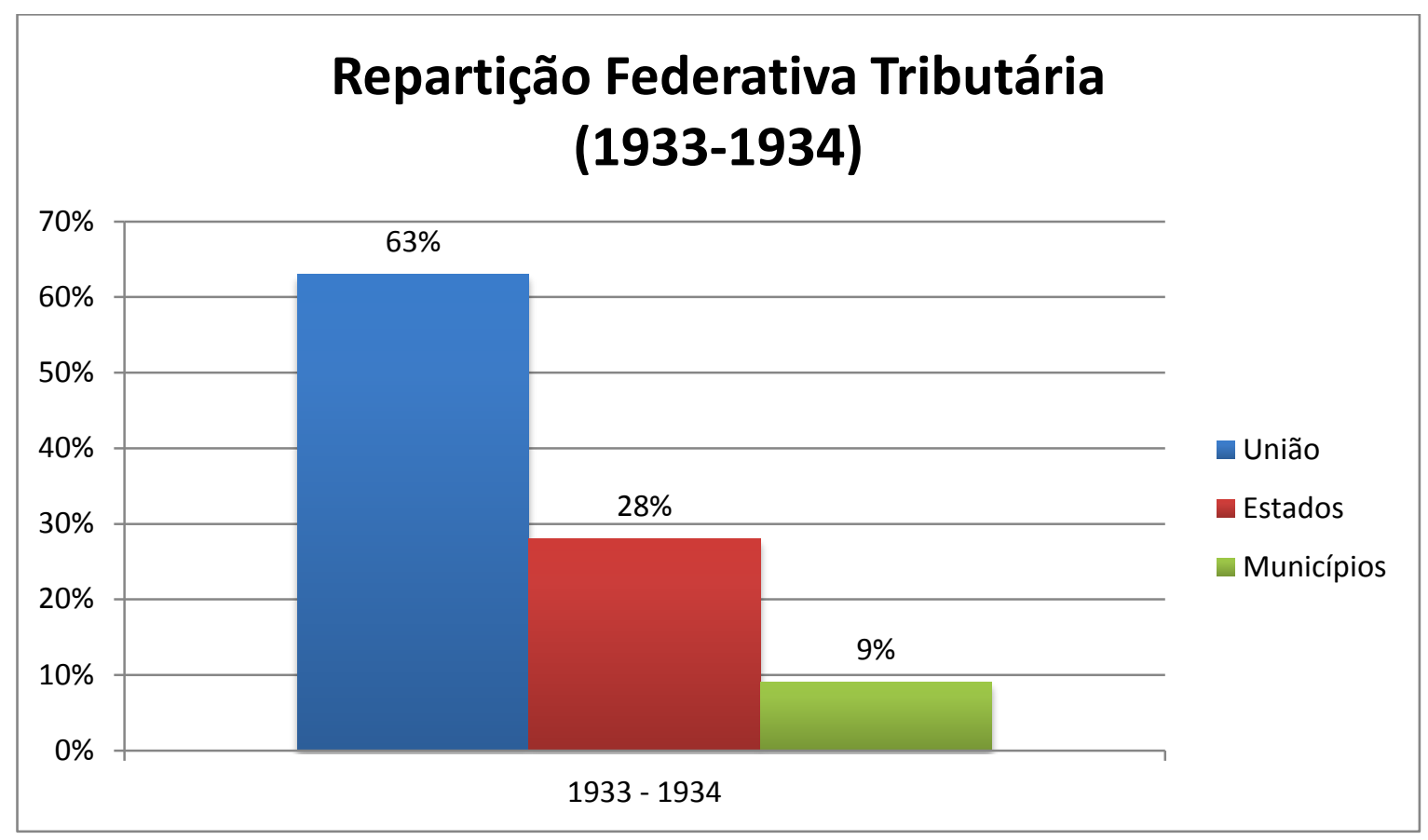

Fonte: LEAL, Victor Nunes. Coronelismo, Enxada e Voto: O Município e o Regime Representativo no Brasil. $7^{\mathrm{a}}$ ed. São Paulo: Companhia das Letras 2012, p. 153.

Apesar de alguns entenderem, como Fabrício Augusto de Oliveira, que o sistema tributário de 1891 representou um fortalecimento dos estados, pois garantiu-lhes autonomia financeira e, inclusive, parte significativa da arrecadação, ${ }^{280}$ é inegável que a solução encontrada não equilibrou a distribuição dos tributos e das receitas. ${ }^{281}$

A situação dos municípios aponta isso com clareza. Premidos pela falta de recursos, os Estados tendiam a comprimir as finanças municipais, restringindo sua capacidade tributária e tributando suas rendas. ${ }^{282}$

Fato é que a repartição de competências tributárias de 1891 se notabilizava por sua permissividade e flexibilidade, sobretudo no âmbito da competência legislativa concorrente entre União e Estados e da delegação aos Estados para definirem o escopo do sistema tributário municipal. O legislador ordinário tinha ampla liberdade para

${ }^{280}$ OLIVEIRA, Fabrício Augusto de, op. cit., p. 20.

281 A esse respeito é elucidativa a frase de Leopoldo de Bulhões "A Constituinte não resolveu a questão da Federação, e a obra dos republicanos, ao ser ultimada, já está carecendo de revisão quanto a vários problemas, entre os quais a discriminação real e completa das rendas" Cit. por: LEAL, Victor Nunes, op. cit. p 149.

282 Ibidem, p. 152. 
instituir os mais variados tributos e as zonas de superposições tributárias eram muitas. $^{283}$

Entre as principais alterações da Constituição de 1934 está a criação de uma esfera tributária municipal autônoma, a abolição dos impostos cumulativos entre os entes, e o surgimento da repartição federativa de receitas de tributos de competência legislativa exclusiva de cada pessoa política.

O modelo se inaugurou com a repartição, com os municípios, do imposto estadual sobre a indústria e a produção. A inovação se consolidaria como o cerne do pacto federativo brasileiro, sustentado na troca de autonomia tributária por transferências involuntárias. Uma definição de competências cada vez mais específica, cuja tendência era concentrar os instrumentos tributários de política econômica na órbita da União.

A nova constituição circunscrevia o imposto sobre vendas e consignações à competência exclusiva dos estados, ao mesmo tempo em que se extinguia a incidência de imposto de exportação - à época também de competência estadual - em transações interestaduais e limitava-se à alíquota máxima do mesmo.

Para Geraldo Ataliba, o modelo inaugurado com a constituição de 1934 era singular no mundo, pela sua absoluta rigidez: ${ }^{284}$

3 - Inaugurou-se em 1934, com a Constituição social-democrática, a rigidez do sistema constitucional tributário brasileiro, que passa a ser característica nossa. É rígido o sistema erigido em 1934. Desapareceu aquela liberdade do legislador ordinário que, de então em diante, passa a se ver peiado, circunscrito a esferas limitadas e onerado por mil amarras. ${ }^{285}$

Houve, contudo, fortes resistências à adoção desse modelo. A bancada paulista na constituinte de 1933 retomou a tese, defendida por Julio de Castilhos e pela bancada gaúcha na constituinte de 1890 , de discriminar as rendas da união e outorgar as fontes remanescentes aos estados. ${ }^{286}$ Ficariam a encargo dos estados todos os serviços atinentes à atividade social (viação, saúde pública, educação, e fomento econômico). ${ }^{287}$

\footnotetext{
${ }^{283}$ ATALIBA, Geraldo op. cit., pp 53 e 57.

${ }^{284}$ Ibidem, p. 61.

${ }^{285}$ Ibidem, p. 66.

${ }^{286}$ LEAL, Victor Nunes, op. cit., p. 154

${ }^{287}$ Ibidem, p. 155.
} 
Entretanto, a alternativa de construção de uma federação calcada em Estados fortes e um poder central limitado acabou não se logrando vitoriosa. Victor Nunes Leal aponta como o modelo idealizado pelo governo, e que saiu vitorioso, passava por fortalecer os municípios sem com isso fortalecer os estados. ${ }^{288}$ Passar-se-ia, assim, cada vez mais federalizar e centralizar na União os mecanismos de política econômica tributária.

Essa tendência se aprofundaria em 1937, com a transferência do imposto cedular sobre a renda de imóveis rurais de competência municipal para União. Assim como com a federalização gradual dos tributos sobre a infraestrutura, energia e combustíveis.

As Leis Constitucionais $\mathrm{n}^{\circ} 3$ de 18 de setembro de 1940 e $^{\circ} 4$ de 20 de setembro de 1940 retiraram dos estados a tributação sobre o carvão mineral, combustíveis e lubrificantes líquidos e transferiram à União o imposto único sobre todas as etapas produtivas destes produtos. Reduzia-se, então, significativamente, a competência tributária estadual.

A constituição de 1946, embora não altere muito o quadro, consolida o modelo de repartição de receitas tributárias que passam a ser acompanhadas de vinculação de seus gastos.

As transferências de imposto único foram vinculadas ao desenvolvimento do sistema de transporte e de empreendimentos ligados com a indústria de petróleo, como lembra Ricardo Varsano. ${ }^{289}$ Da mesma forma que pelo menos metade dos recursos do imposto de renda recebidos pelos municípios deveria ser aplicada em benefícios de ordem rural, como obras ou serviços que promovessem melhorias nas condições sanitárias, sociais ou culturais das populações rurais. ${ }^{290}$

Além disso, ela previa em seu artigo $5^{\circ}$, inciso XV, alínea "b", a competência concorrente da União e estados para legislarem sobre normas gerais de direito financeiro, cabendo aos estados a competência supletiva ou complementar. ${ }^{291}$ Dessa maneira, inclusive, abria-se o caminho para a elaboração de um código tributário nacional, ideia que ganhava força com o intuito de racionalizar e unificar os padrões de

\footnotetext{
${ }^{288}$ Ibidem, p. 157.

${ }^{289}$ VARSANO, Ricardo, op. cit., p. 5.

${ }^{290}$ Idem

${ }^{291}$ Constituição 1946.
} 
regulação acerca dos prazos prescricionais, regras de solidariedade, bases de cálculo e conceitos de fato gerador.

Dessa forma, os vetores de organização do sistema em formação já começam a apontar para tendência de um federalismo fiscal em que a autonomia de tributar e legislar dos estados e municípios são cada vez mais limitadas. A própria ideia de um sistema tributário único e nacional conduz a necessidade de uniformidade de regramento em todo o território, fortalecendo as tendências de transferir para órbita federal a capacidade de legislar sobre a matéria. ${ }^{292}$

Fato esse que se reforça com a criação do sistema de transferências constitucionais obrigatórias da receita tributária da União com os estados e municípios. Traços também de um modelo de federalismo cooperativo. ${ }^{293}$

${ }^{292}$ ATALIBA, Geraldo, op. cit., p. 66. Segundo Geraldo Ataliba: "Praticamente, as linhas mestras do sistema erigido pelas Constituições de 1937 e 1946 são as mesmas que as inauguradas em 1934.”

${ }^{293}$ BERCOVICI, Gilberto. Dilemas do Estado Federal Brasileiro. Porto Alegre: Livraria do Advogado, 2004, pp. 32 e 42 . 


\section{2 - A Construção de um Sistema Tributário Nacional}

\subsection{1 - As Reformas da Década de 1960}

As linhas mestras do Sistema Tributário Nacional, como conhecemos hoje, foram traçadas entre 1965 e 1969, com a última grande reforma tributária que ocorreu no país. Seus marcos são a publicação da emenda constitucional $n^{\circ} 18$, de 6 de dezembro de 1965, e um ano depois da Lei 5.172 de 25 de outubro de 1966 o Código Tributário Nacional.

Embora a constituição de 1988 tenha realinhado o equilíbrio do pacto federativo tributário, bem como do volume da carga fiscal, não houve inovação substancial quanto à estruturação dessas duas tensões. O exercício das competências tributárias segue semelhante modelo - inclusive recepcionando boa parte da legislação infraconstitucional do período anterior - e as fontes de financiamento tributário sobre a economia nacional, exceto na órbita federal, pelo crescimento do imposto de renda e pela criação das varias contribuições sociais, sofrem poucas alterações significativas.

Apesar de muitos elementos do novo sistema já estarem inscritos de forma embrionária no anterior, como já apontamos ao abordar os antecedentes da reforma, ela representou uma verdadeira ruptura com a repartição federativa fiscal da época, com uma inflexão substancial na trajetória das tensões já existentes. A esse respeito comentava Bernardo Ribeiro de Moraes:

\footnotetext{
A evolução histórica de nossa discriminação de rendas nos mostra que as mudanças fiscais estabelecidas nas Constituições de 1934, 1937 e 1946, em que pesem os pontos positivos aceitos, se limitaram a adotar o sistema tributário de 1891. (...) A Emenda Constitucional $\mathrm{n}^{0}$ 18, de 1965, não mais copiou comodamente o sistema fiscal anterior, trazendo, ao País, uma reforma tributária propriamente dita, ratificada pela atual Constituição do Brasil. ${ }^{294}$
}

Foi somente após o golpe militar, por meio do PAEG (Plano de Ação Econômica do Governo), que a estrutura tributária de um Brasil urbano e industrial foi consolidada

\footnotetext{
${ }^{294}$ RIBEIRO. Bernardo. Infra-Estrutura Tributária. Doutrina RDP-2, p 92.
} 
e organizada. $^{295}$ Sem dúvida, a conjuntura política excepcional contribuiu enormemente para o arrefecimento da disputa federativa, o que permitiu a reforma promover mudanças profundas.

Segundo a própria definição do plano, elaborado sob a coordenação dos Ministros da Fazenda e do Planejamento, respectivamente, Roberto Campos e Octavio Gouveia Bulhões, sua política tributária visava a fortalecer a arrecadação e corrigir as distorções de incidência, estimulando a poupança, melhorando a orientação dos investimentos privados e atenuando as desigualdades econômicas regionais e setoriais. ${ }^{296}$

De acordo com Fabrício Augusto de Oliveira, os principais objetivos da reforma eram elevar a captação de recursos financeiros e transformar o sistema tributário numa poderosa ferramenta do processo de acumulação que começava a se redesenhar. ${ }^{297}$

A busca dessas metas impunham três importantes diretrizes para a reforma: a) transferir para União a competência da arrecadação da maioria dos tributos; b) aprimorar as técnicas de arrecadação e de incidência dos tributos alargando suas bases; c) centralizar na União as decisões sobre a aplicação dos recursos estaduais e municipais de forma a permitir uma ação coordenada do Estado no processo de acumulação. $^{298}$

Há um razoável consenso entre os economistas do setor público de que a reforma tributária implementada pelo PAEG representou significativos avanços, pois dotou o sistema de maior racionalidade interna e maior efetividade econômica. Fabrício Augusto de Oliveira considera que ela foi um divisor de águas entre o sistema precedente, sem maiores preocupações de ordem econômica, e o sistema que dela emergiu, tornando os tributos passíveis de utilização enquanto instrumentos de política econômica. $^{299}$

\footnotetext{
${ }^{295}$ Apesar do enfoque no modelo administrativo da reforma, para se ter uma visão panorâmica do escopo institucional e jurídico do PAEG ver: BERCOVICI, Gilberto. O Direito Constitucional passa e o Direito Administrativo fica. In: TELES, Edson; e SAFATLE, Vladimir (orgs.). O que Resta da Ditadura. São Paulo: Boitempo, 2010. Suas considerações sobre a perenidade do direito administrativo ali concebido podem ser replicadas integralmente para o direito tributário.

${ }^{296}$ REZENDE, André Lara. Estabilização e Reforma: 1964-1967. In: ABREU, Marcelo de Paiva (org.). A Ordem do Progresso: Cem Anos de Política Econômica Republicana, 1889-1989. Rio de Janeiro: Campus, 1990, pp. 213 e 214.

${ }^{297}$ OLIVEIRA, Fabrício Augusto de, op. cit., p. 49.

${ }^{298}$ Idem.

${ }^{299}$ Ibidem, p. 82.
} 
Também afirma Tomás Bruginsk de Paula que nesse momento ocorre a constituição de um efetivo sistema tributário nacional, conferindo organicidade à estrutura, concentrando na União o controle dos principais impostos de política econômica, como o de exportação e de operações financeiras, corrigindo as incidências cumulativas dos impostos sobre a produção e aprimorando as relações tributárias. ${ }^{300}$

$\mathrm{Na}$ literatura jurídica, porém, o debate é intrincado. Geraldo Ataliba foi franco opositor da reforma implementada, pelo menos até a nova constituição de 1967, sobretudo por seu redesenho do federalismo fiscal e da repartição de competências. Em seu trabalho, Sistema Constitucional Tributário Brasileiro, publicado em 1968, ele esclarece que a motivação de sua obra foi recuperar a tradição constitucional tributária brasileira em face dos equívocos advindos da reforma tributária de 1965.

31. Daí o retrocesso que a simploriedade de concepção ditou quando da elaboração da emenda constitucional $\mathrm{n}^{\circ}$ 18: o retôrno ao estado unitário e imperial, com a postergação das províncias e eliminação dos municípios. Isto tudo está patentemente implícito em cada têrmo da emenda constitucional, como de sua sistemática e seu espírito. ${ }^{301}$

Prossegue, ainda, em sua nota introdutória à obra:

46. Ora, federação é associação de estados. Estado é ente político autônomo. Autônomo quer dizer: senhor dos instrumentos de sua autonomia, dentre os quais avultam os recursos financeiros. Logo, a emenda que indiretamente venha subordinar o estado à União - como é o caso - em matéria financeira, infringe o princípio federal, ao solapar a condição "sinequa non" da autonomia, que é o instrumento financeiro. ${ }^{302}$

Rubens Gomes de Souza, por outro lado, via como fundamentais as alterações no federalismo tributário, sobretudo por conta das distorções que provocavam na prática:

Teoricamente, essas áreas eram rigidamente separadas e distintas, e os impostos incluídos em cada uma eram diferentes dos das outras. Na prática, porém, a

${ }^{300}$ DE PAULA, Tomás Bruginsky. Padrões de Financiamento do Setor Público - Uma Análise do Sistema Fiscal e do Setor Produtivo Estatal no Brasil. Campinas: Unicamp - Instituto de Economia. Dissertação de Mestrado, 1989, p. 41.

${ }^{301}$ ATALIBA, Geraldo, op. cit., p. 20.

302 Ibidem, p. 24. 
interpenetração ocorria entre elas, e impostos de governos diferentes, quando não os do mesmo govêrno, efetivamente se sobrepunham. (...)

A causa principal dessa situação era o fato, já notado, de definir a Constituição os impostos por critérios jurídicos e não econômicos. Isso possibilitava distorções de conceitos jurídicos, ou de interpretações jurisprudenciais, que conduziam à coexistência de impostos formalmente distintos mas substancialmente idênticos. ${ }^{303}$

Posteriormente, conclui ainda elogiando a reforma:

\begin{abstract}
A reforma tributária brasileira representa uma nova, por vêzes ousada, experiência de govêrno, de saneamento econômico, e de maior justiça social. A contingência comum a todos os empreendimentos humanos é que só a experiência prática lhes pode confirmar os objetivos. Mas pelo menos êste autor está convicto de que o Brasil deu mais um passo firme na trilha aberta pelo potencial dos seus recursos econômicos e humanos. ${ }^{304}$
\end{abstract}

A constituição de 1967 reproduziu e consolidou as mudanças realizadas pela emenda constitucional $n^{\circ} 18$ de 1965, com alguns pequenos ajustes. Entre eles restituiu os poderes da União para instituir novos tributos, além dos previstos na constituição, atenuando a redação draconiana do artigo $5^{\circ}$ da emenda constitucional $n^{\circ} 18$ de 1965 , porém mantendo a vedação aos estados e municípios de o fazerem. ${ }^{305}$ Também, diferentemente do gatilho previsto na constituição de 1946, de necessária repartição das receitas de novos tributos eventualmente criados, o texto constitucional de 1967 eximia a União de partilhá-las.

As demais mudanças no capítulo do sistema tributário na constituição ativeram-se mais à técnica legislativa do que ao conteúdo. Retomou-se a disposição dos tributos baseada por ente da federação em oposição à sistemática do CTN, que organizava os tributos pelo setor econômico em que incidia. Fato esse que, entre outros, levou Geraldo Ataliba a considerar que a constituição de 1967 retomou a tradição constitucional tributária brasileira. ${ }^{306}$

\footnotetext{
${ }^{303}$ SOUZA, Rubens Gomes de. A Reforma Tributária no Brasil. RDA. Vol 87. Jan-Mar, 1967, pp. 2/3. ${ }^{304}$ Ibidem, p. 16.

${ }^{305}$ Art. $19, \S 6^{\circ}$ - A União poderá, desde que não tenham base de cálculo e fato gerador idênticos aos dos impostos previstos nesta Constituição, instituir outros além daqueles a que se referem os arts. 22 e 23 e que não se contenham na competência tributária privativa dos Estados, Distrito Federal e Municípios, assim como transferir-lhes o exercício da competência residual em relação a determinados impostos, cuja incidência seja definida em lei federal.

${ }^{306}$ ATALIBA, Geraldo, op. cit., pp. 3, 4 e 207.
} 
Porém, como já afirmamos, a reforma tributária implementada pelo PAEG também aproveitou estruturas do passado. A forte tendência centralizadora dos principais tributos na competência da União foi a solução possível dentro do quadro institucional do federalismo brasileiro, que havia sido construído sobre os pilares da designação de exclusividade na cobrança de impostos e transferências intergovernamentais compensadoras dos desequilíbrios verticais e horizontais. ${ }^{307}$ Uma vez que a ampla liberdade das três esferas de governo para instituir seus próprios tributos, acessando bases comuns de incidências, as estimulava a se comportarem sem compromisso com os impactos de suas decisões, ${ }^{308}$ buscou-se criar o federalismo de repartição das receitas, com a criação do FPE e do FPM, aprofundando outra tendência já existente.

Sob a perspectiva da política econômica, o novo sistema tributário se mostraria capaz de desempenhar um papel significativo na atuação do Estado brasileiro. Nesse sentido, é elucidativa a afirmação do próprio Octávio Gouvêa de Bulhões de que a reforma tributária de 1965 traçava uma nítida distinção entre tributos com finalidade fiscal e extrafiscal, sendo os últimos os que tinham por base a exportação de mercadorias e as operações fiscais. ${ }^{309}$

A política tributária, conduzida exclusivamente pela União, passaria a assumir objetivos de distintas ordens, que não mais se limitariam a arrecadação de recursos (muito embora o aumento da carga tributária bruta de 18\% para 24\%, alcançado entre 1963 e 1966, já apontasse também um grande salto qualitativo nesse objetivo). ${ }^{310}$

Dotada dos meios adequados para tanto, a União passaria a orientar as atividades econômicas, por meio da tributação, estimulando a formação de poupanças individuais e de empresas - pela dedução das poupanças da incidência do IR e pela diferenciação entre lucros líquidos e reinvestidos - e estimulando investimentos em determinados setores pela diferenciação de alíquota sobre os produtos industrializados.

\footnotetext{
${ }^{307}$ ARAÚJO, Erika Amorim. A Tributação do Consumo pela Sistemática do Valor Adicionado em Contextos Federativos: Problemas e Possíveis Alternativas para Lidar com a Questão. Campinas: Unicamp - Instituto de Economia. Dissertação de Mestrado, 1999, pp. 132 e 133.

${ }^{308}$ Idem.

${ }^{309}$ BULHÕES, Octávio Gouvêa de. Aspectos da Reforma Tributária. In: Revista de Direito Administrativo. Vol. 113, Rio de Janeiro, 1973, p. 1. Assim explicitou o próprio ministro da Fazenda do período: “O projeto preparado pelo executivo em 1965, submetido à consideração do congresso, traçava um roteiro original, de nítida distinção entre tributos com finalidade de receita de tesouraria e tributos com finalidade de política monetária. Esses últimos, de competência da União, tinham por base a exportação de mercadorias para o exterior e as operações financeiras."

${ }^{310}$ OLIVEIRA, Fabrício Augusto de, op. cit. p. 83.
} 
Dessa forma a tributação passaria a ser instrumento eficaz da política de crescimento e desenvolvimento adotada pelo governo militar. Segundo Bernardo Ribeiro de Moraes, veio integrar a política tributária na política econômica. ${ }^{311}$

A despeito dos avanços em comparação à estrutura disfuncional anterior, a reforma de 1966 acabou por tocar apenas nos conflitos de ordem federativa e de eficiência econômica, eclipsando a questão do perfil regressivo da tributação brasileira. Muito embora a reforma tenha apresentado ganhos técnicos relevantes diante da desordem anterior do sistema, ${ }^{312}$ consolidou-se um modelo em que a principal fonte tributária de receitas fiscais do Estado passou a ser dos impostos indiretos incidentes sobre o consumo, principalmente o ICM e o IPI. ${ }^{313}$

A esse respeito é precisa a constatação de Erika Amorim Araújo, de que passamos de um modelo sustentado pela tributação de mercadorias produzidas no exterior e consumidas internamente para um modelo sustentado na tributação de mercadorias produzidas internamente. ${ }^{314}$ A principal fonte de financiamento do Estado seguiu sendo a tributação indireta, ainda que realizada de forma mais coordenada e racional da perspectiva do mercado.

A exceção a esse quadro deveria ser o reestruturado Imposto de Renda, que permitiria compensar a regressividade dos impostos sobre o consumo por meio de seu caráter progressivo. Entretanto, a sua utilização durante o regime militar foi marcada pelo estímulo à concentração de renda, por meio da concessão indiscriminada de isenções, deduções, abatimentos e reduções de alíquotas de forma a agravar a regressividade. $^{315}$

\subsection{2 - A Emenda Constitucional $n^{\circ} 18$ de 1965 e a Constituição de 1967}

A emenda constitucional criava, de certa maneira, o capítulo do sistema tributário nacional na constituição de 1946, inaugurando algo que depois se manteria nas

\footnotetext{
${ }^{311}$ RIBEIRO, Bernardo. op. cit., p. 93.

${ }^{312}$ Ibidem, p. 82.

${ }^{313}$ Destaque-se que anteriormente a constituição de 1988 o ICM, que fora substituído pelo ICMS, era um tributo sem seletividade alguma. Incidia a mesma alíquota sob qualquer produto que fosse objeto de circulação.

${ }^{314}$ ARAÚJO, Erika Amorim, op. cit. p. 132.

${ }^{315}$ OLIVEIRA, Fabrício Augusto de, op. cit. p. 138.
} 
constituições seguintes. Composta de 26 artigos, ela reestruturava todos os impostos federais, estaduais e municipais, alterava a repartição de receitas e incluía limitações ao poder de tributar, como observação explícita da anterioridade ou mesmo imunidade de templos religiosos, livros e partidos políticos.

Além da reestruturação do sistema de repartição de receitas e do sistema tributário o que representou a extinção de determinados tributos, alteração de outros e criação de novos - chama a atenção a sua preocupação em restringir as fontes e a competência legislativa do direito tributário brasileiro.

Logo em seu artigo $1^{\circ}$, ela já estabelecia as fontes do direito tributário brasileiro e em seu artigo $5^{\circ}$ deixava claro que os impostos existentes no sistema tributário nacional eram exclusivamente os por ela previstos.

Essas preocupações apontam a busca de tornar perene o arranjo institucional ali estabelecido e dificultar futuras mudanças. Nesse mesmo sentido que a previsão detalhada das limitações ao poder de tributar procurava antes proteger a economia nacional de políticas tributárias descoordenadas - garantindo previsibilidade e segurança jurídica ao setor privado - do que proteger o cidadão dos poderes do físco.

\subsubsection{1. - Mudanças de Incidência}

Quanto às mudanças horizontais no sistema, atinentes aos tipos de impostos e forma de incidência e cobrança, a diretriz clara da emenda constitucional $\mathrm{n}^{0} 18$ era sanear o sistema tributário, extinguindo a proliferação de figuras tributárias de construção puramente jurídico-formais, e substituí-los por tributos pensados em acordo com as linhas da política econômica para o período. ${ }^{316}$

Dessa maneira que sua própria organização temática dos tributos por setor dava a tônica de um sistema tributário organizado pelas finalidades da incidência de seus tributos e não mais pelas destinações de suas receitas. Fato considerado por alguns

${ }^{316}$ OLIVEIRA, Fabrício Augusto de, op. cit. p. 51. 
juristas uma miopia dos autores da reforma, por confundir problemas funcionais com estruturais. $^{317}$

Tornava-se prioritária a compreensão econômica dos impactos da tributação, apesar das liberdades políticas atinentes à autonomia dos membros da federação brasileira.

\begin{abstract}
Desde 1891 vem sendo seguido o critério, peculiar às Constituições brasileiras, de partilhar tributos designados por suas denominações jurídicas usuais, posto que nem sempre pacíficas para os próprios juristas. Êsse sistema tem provocado ou facilitado distorções econômicas, e mesmo problemas estritamente jurídicos, que o crescimento das necessidades financeiras do poder público, e a conseqüente complexidade e onerosidade dos tributos federais, estaduais e municipais sòmente tendem a agravar. ${ }^{318}$
\end{abstract}

Extinguiam-se os impostos sobre o selo, sobre indústrias e profissões, sobre diversões públicas e o chamado imposto de licença. Em sua substituição foram criados os impostos sobre operações financeiras (ISOF) e sobre serviços de qualquer natureza (ISSQN). Os impostos sobre vendas e consignação e sobre o consumo foram alterados para, respectivamente, imposto sobre a circulação de mercadorias (ICM) e imposto sobre produtos industrializados (IPI). Já os impostos de transmissão de bens imóveis intervivos e causa-mortis foram fundidos em um único imposto de transmissão de bens imóveis (ITBI).

Os demais impostos foram mantidos, entre eles os impostos de importação e exportação, o imposto de renda, o imposto sobre a propriedade territorial e urbana, o imposto sobre a propriedade rural e os impostos incidentes sobre combustíveis, energia elétrica, lubrificantes e minerais.

${ }^{317}$ ATALIBA, Geraldo, op. cit., p. 230, nota 15. Nos parece que a preocupação dele reflete o clássico debate da teoria do direito tributário acerca da designação econômica do fato gerador.

${ }^{318}$ Vide: ATALIBA, Geraldo. op. cit.1968, p. 232. 


\section{Anterior à Emenda no 18}

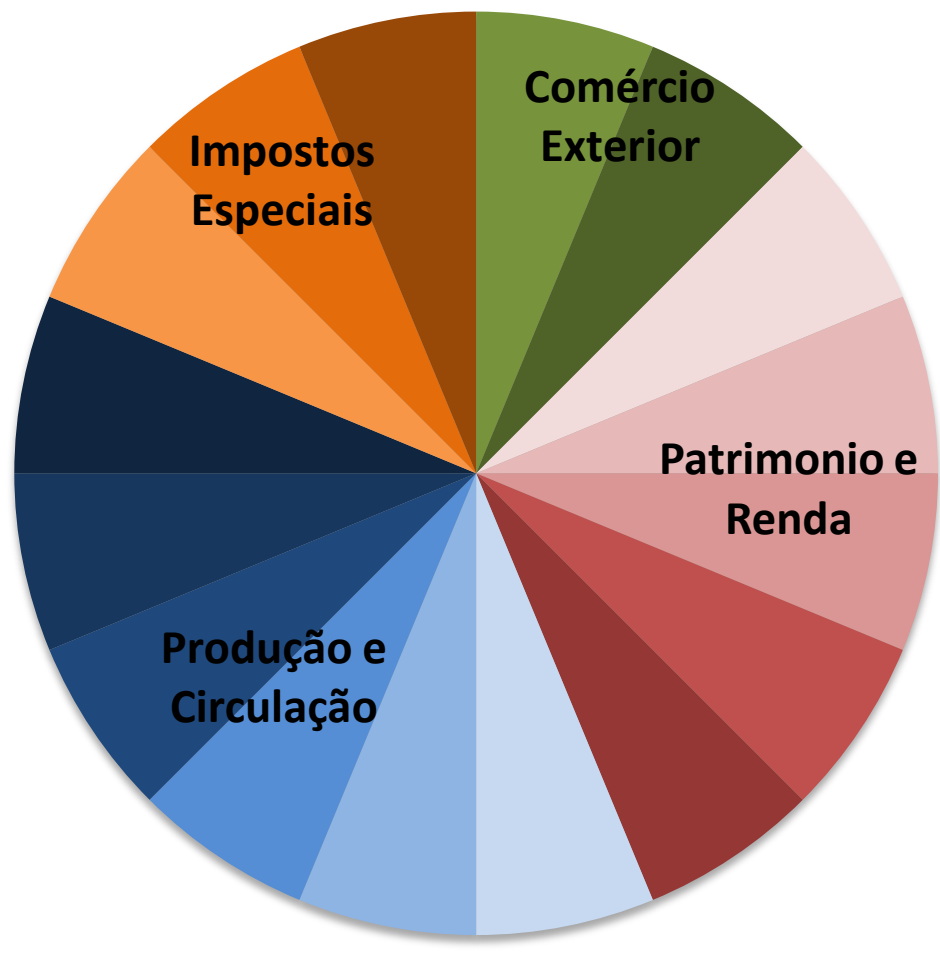

Imposto sobre a Exportação

- Imposto sobre a Importação

Imposto sobre a Propriedade Territorial Urbana

Imposto sobre a Propriedade Territorial Rural

- Imposto sobre a Renda e Proventos de Qualquer Natureza

- Imposto sobre Transmissão de Bens Imóveis "Causa-Mortis"

- Imposto sobre Transmissão de Bens Imóveis "Intervivos"

- Imposto sobre o Consumo

Imposto sobre Vendas e Consignações

- Imposto do Selo

— Imposto sobre Indústria e Profissões

— Imposto sobre Diversões Públicas

- Imposto de Licença

Imposto sobre Minerais

- Imposto sobre Energia Elétrica

- Imposto sobre Combustíveis e Lubrificantes

\section{Posterior à Emenda no 18}

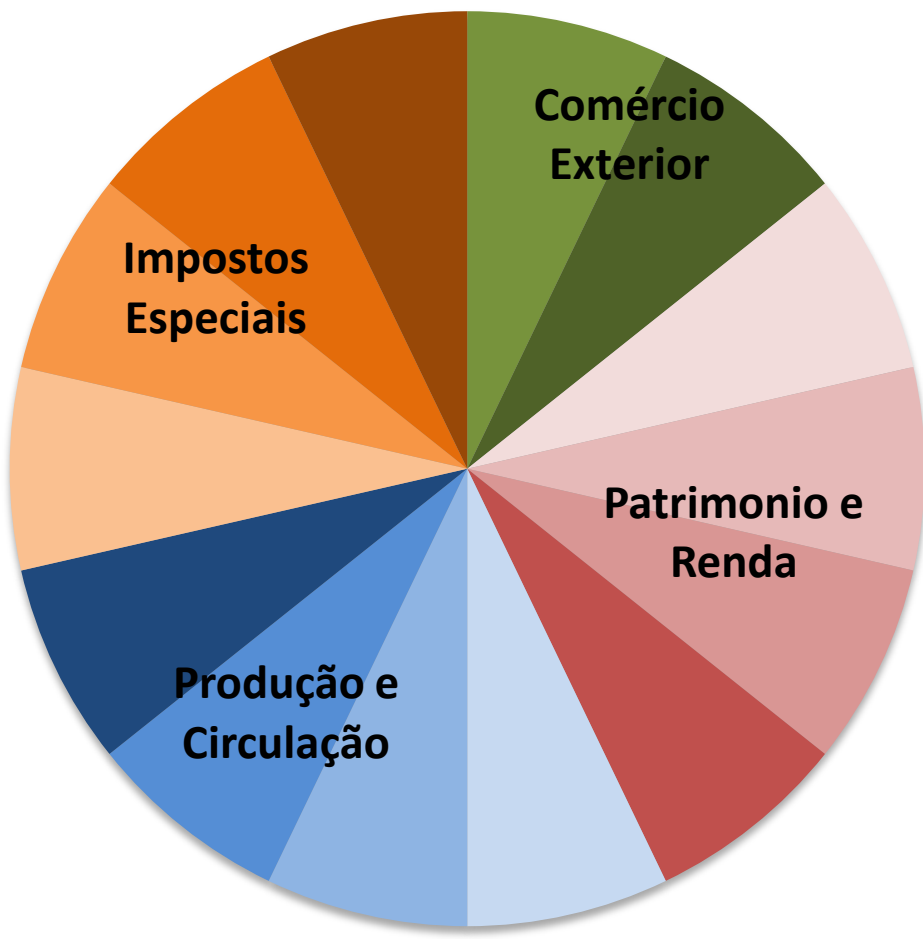

- Imposto sobre a Exportação

- Imposto sobre a Importação

Imposto sobre a Propriedade Territorial Urbana

Imposto sobre a Propriedade Territorial Rural

- Imposto sobre a Renda e Proventos de Qualquer Natureza

- Imposto sobre Transmissão de Bens Imóveis

Imposto sobre Produtos Industrializados

- Imposto sobre a Circulação de Mercadorias

Imposto sobre Operações Financeiras

- Imposto sobre Serviços de Qualquer Natureza

Imposto sobre Serviços de Transporte e Comunicações

- Imposto sobre Minerais

- Imposto sobre Energia Elétrica

- Imposto sobre Combustíveis e Lubrificantes 
Não resta dúvida, porém, de que as principais mudanças concentraram-se nos tributos sobre a produção e a circulação de mercadorias. Não apenas pela alteração de impostos, mas por toda a engenharia jurídica e financeira que acompanhou essas mudanças.

A criação do ICM, em substituição ao IVC, e do IPI, em substituição ao imposto sobre o consumo, representou a formação dos primeiros impostos sobre o valor agregado da América Latina, hoje muito utilizados em diversos países, mas que à época existiam apenas na França. ${ }^{319}$

A incidência não cumulativa de ambos sobre as etapas produtivas e de circulação, representou uma correção das distorções econômicas, retirando os estímulos existentes à integração vertical das empresas. ${ }^{320}$ Ademais, a tributação de múltiplos estágios, da produção e da circulação, diminuía as possibilidades de sonegação fiscal uma vez que a comprovação do recolhimento do tributo na etapa anterior é essencial para seu abatimento na etapa futura. ${ }^{321}$

No caso particular do ICM, esse efeito foi mais significativo, uma vez que a simples circulação interna, durante o processo de fabricação, escapava ao conceito jurídico de venda a comprador independente, favorecendo a integração. ${ }^{322}$

Outro problema antigo que se buscava solucionar era o das operações mercantis interestaduais. $\mathrm{O}$ estado de origem procurava tributar a mercadoria por ser produzida em seu território, e o estado de destino empenhava-se em tributar a mesma mercadoria por ser consumida em seu território. Com a mudança do imposto sobre vendas para o imposto sobre a circulação, bem como com a previsão de uma alíquota limite a ser regulada pelo Senado Federal, pretendia-se dar solução para esse problema. ${ }^{323}$

Quanto ao IPI, o principal efeito resultante de sua adoção foi a sua melhor compatibilização com o ICM. Isso, pois a incidência do IVC e do antigo Imposto sobre o consumo era muito semelhante, e seu encargo acabava sendo recolhido pelo mesmo contribuinte, que repassava seus custos para toda a cadeia. Na medida em que o IPI

\footnotetext{
${ }^{319}$ VARSANO, Ricardo, op. cit., p. 8. Ver também: GOMES DE SOUZA, Rubens. A Reforma Tributária no Brasil. In: RDA. Vol 87. Jan/Mar, Ano 1967. Rio de Janeiro, p. 9.

${ }^{320}$ OLIVEIRA, Fabrício Augusto de, op. cit. P. 53.

${ }^{321}$ QUADROS, Waldenir Luiz de. op. cit., p. 9.

${ }^{322}$ SOUZA, Rubens Gomes de, op. cit., p. 9.

${ }^{323}$ Ibidem, p. 11.
} 
passou a incidir apenas na fase industrial, harmonizou-se com o ICM. Outro ponto relevante foi a adoção da seletividade do IPI em razão da natureza dos produtos. ${ }^{324}$

A extinção dos impostos sobre indústria e profissões, sobre diversões públicas e de licença veio no sentido de racionalizar o sistema, trazendo para a ordem constitucional o problema do sistema tributário dos municípios. Tendo sido relegado aos estados discipliná-los até o momento, as figuras mais anacrônicas do sistema tributário tinham se desenvolvido em torno do financiamento municipal, uma vez que as competências residuais acabavam permitindo espaços para tributação repetida de atividades já tributadas pelos estados e pela União.

Dessa forma, o imposto sobre indústria e profissões acabou tornando-se uma espécie de imposto sobre vendas e consignações municipal, ${ }^{325}$ assim como o imposto de licença, que na verdade possuía natureza jurídica de taxa. ${ }^{326}$ No mesmo sentido, a substituição do imposto sobre diversões públicas pelo imposto sobre serviços de qualquer natureza representava um melhor enquadramento jurídico das atividades que ensejavam esta tributação.

\subsubsection{2. - Mudanças de Competência}

Também merecem bastante destaque as mudanças promovidas pela emenda constitucional $\mathrm{n}^{\circ} 18$ de 1965, no campo das competências tributárias. A reorganização do federalismo brasileiro promovida talvez seja o principal ajuste realizado por toda a reforma tributária do período, e constituiu um dos traços mais perenes do sistema tributário brasileiro.

O diagnóstico neste campo era de que se fazia necessário eliminar a possibilidade de estados e municípios desempenharem políticas econômicas por meio da tributação, centralizando na União os principais impostos com potencial de impacto sobre a política econômica, retirando as suas competências residuais para criação de novos impostos, ainda que não concorrentes, e garantindo amplas competências ao Senado Federal para arbitrar e definir os limites da gestão tributárias dos estados.

\footnotetext{
${ }^{324}$ Idem.

${ }^{325}$ OLIVEIRA, Fabrício Augusto de, op. cit., p. 52.

${ }^{326}$ SOUZA, Rubens Gomes de, op. cit., p. 14.
} 
O quadro se torna claro quando comparamos os dois momentos em termos de titularidade dos impostos por ente da federação, como se percebe no gráfico abaixo:

\section{Anterior à Emenda no 18}

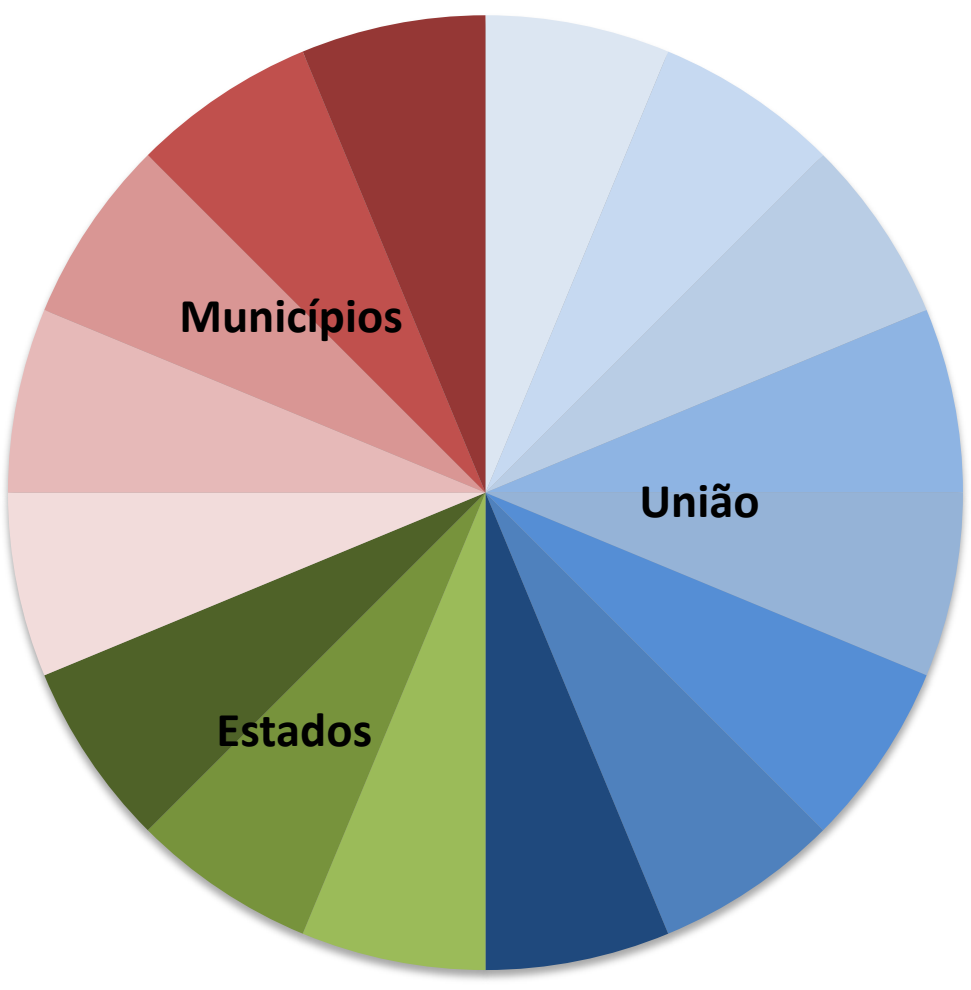

Imposto sobre a Importação

Imposto sobre o Consumo

Imposto do Selo

Imposto sobre a Propriedade

Territorial Rural

- Imposto sobre a Renda e Proventos de Qualquer Natureza

Imposto sobre Minerais

- Imposto sobre Energia Elétrica

- Imposto sobre Combustíveis e

Lubrificantes

- Imposto sobre a Exportação

Imposto sobre Vendas e Consignações

- Imposto sobre Transmissão de Bens Imóveis "Causa-Mortis"

Imposto sobre Diversões Públicas

Imposto de Licença

- Imposto sobre Indústria e Profissões

- Imposto sobre Transmissão de Bens Imóveis "Intervivos"

- Imposto sobre a Propriedade

Territorial Urbana 


\section{Posterior à Emenda no 18}

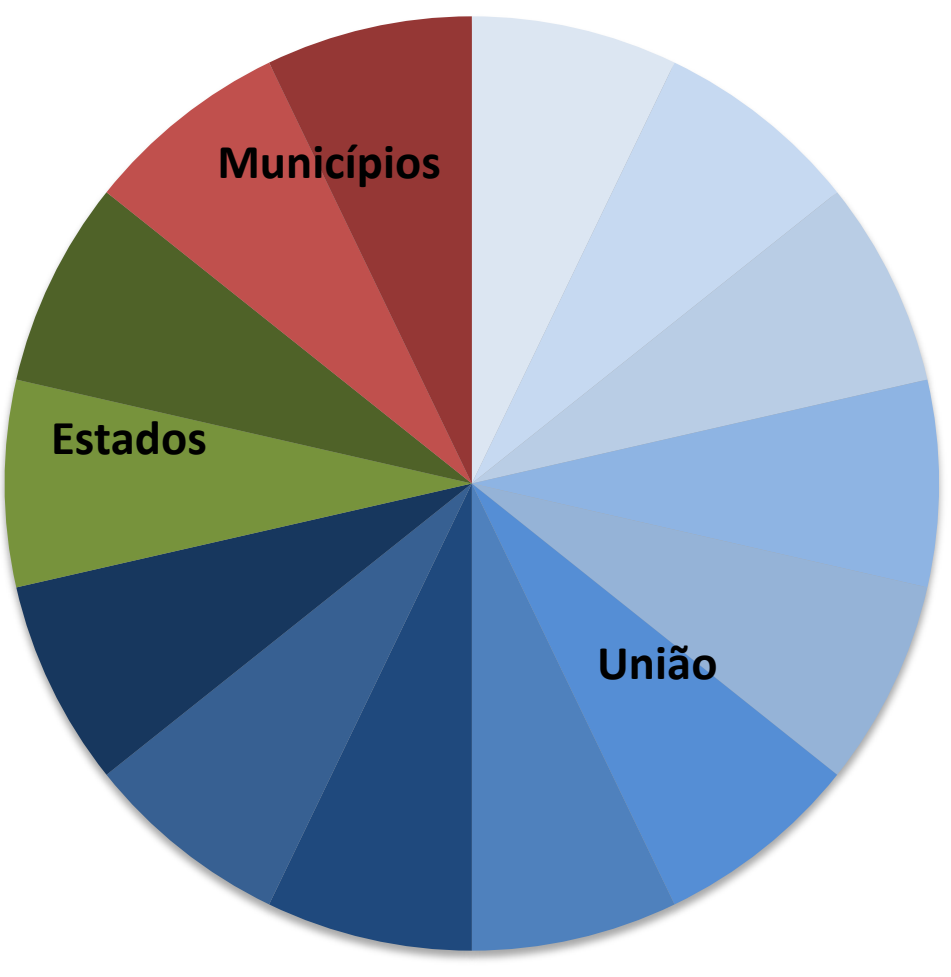

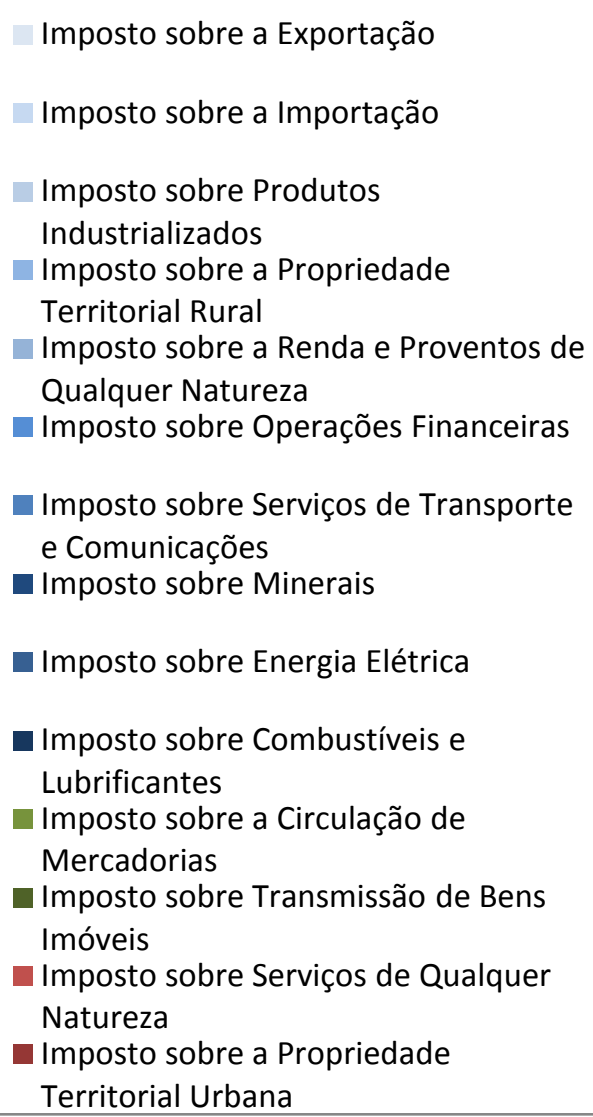

Obs: Os dados referentes ao quadro da tributação anterior a emenda referem-se a distribuição de competências em vigor no momento anterior a vigência da emenda constitucional nº 18 de 1965.

Entretanto, frise-se que muitas mudanças já vinham em curso.

O próprio Octavio Gouveia de Bulhões, na exposição de motivos da reforma tributária de 1966, afirmava a importância de garantir à União o controle dos impostos de exportação e sobre movimentações financeiras:

7. Além dos aspectos assinalados, convém ressaltar que a reforma tributária tem, igualmente, por escopo oferecer meios de disciplina monetária.

Acredito estarmos em condições de sugerir ao legislador dispositivos constitucionais que facultem ao Conselho Monetário Nacional o uso de dois impostos que muito se adaptam à política monetária, ao passo que mantidos conforme o são atualmente constituem entraves à economia do País.

$\mathrm{O}$ imposto de exportação e o imposto sobre transações financeiras - o denominado imposto de selo - são condenáveis se exigidos com a finalidade de suprir recurso de tesouraria (...). Por outro lado, são excelentes meios de formação de reservas. ${ }^{327}$

${ }^{327}$ BALEEIRO, Aliomar. Direito Tributário Brasileiro. Rio de Janeiro: Forense, 1970, p. 32. 
Dessa forma, com a centralização e o controle efetivo da União sobre os principais impostos, abria-se caminho para transformar o sistema tributário em um poderoso instrumento da política econômica do governo federal.

Entretanto, as mudanças foram ainda mais profundas, pois foi vedada aos estados e municípios a criação de outros tributos que não os já existentes. Mesmo nos impostos já existentes de competência dos estados, a União obteve meios para restringir as margens de possíveis distorções, na medida em que a emenda constitucional $\mathrm{n}^{\mathrm{o}} 18$ previa a competência para o Senado Federal estabelecer as alíquotas máximas incidentes sobre as operações de circulação de mercadorias. ${ }^{328}$

Como argumenta Ricardo Varsano, o sistema foi pensado de forma que os entes subnacionais contassem com recursos suficientes para sustentar suas funções, mas sem capacidade de interferir no processo de crescimento do país. ${ }^{329}$ Nesse sentido, além do controle do ICM, para que ele não fosse utilizado como instrumento de política econômica, as transferências de receitas previstas foram parcialmente vinculadas a gastos compatíveis com os interesses da política econômica do governo central. ${ }^{330}$

Foi diante de todo esse quadro que Fabrício Augusto de Oliveira destacou que o grande traço da reforma foi procurar abolir a coexistência de três sistemas tributários autônomos para construir um único campo jurídico e econômico integrado capaz de ser objeto de uma coordenada política econômica. ${ }^{331}$

Interesse esse manifestado no próprio relatório que embasou o anteprojeto da emenda constitucional $\mathrm{n}^{\mathrm{o}} 18$ :

\footnotetext{
A segunda premissa é a concepção do sistema tributário como integrado no plano econômico e jurídico nacional, em substituição ao critério, atual e histórico, de origem essencialmente política, da coexistência de três sistemas tributários autônomos, federal, estadual e municipal. ${ }^{332}$
}

Esse ponto, porém, foi alvo de muitas críticas que levaram a recuos na reforma, por ocasião da constituição de 1967. A esse respeito Geraldo Ataliba comenta:

\footnotetext{
${ }^{328}$ Art $12, \S 1^{\circ}$.

${ }^{329}$ VARSANO, Ricardo, op. cit., p. 9.

${ }^{330}$ Idem.

${ }^{331}$ OLIVEIRA, Fabrício Augusto de, op. cit., p. 58.

332 Cit por: ATALIBA, Geraldo. Sistema Constitucional Tributário Brasileiro. São Paulo: Revista dos Tribunais: 1968 , p. 224 e 225.
} 
(...) não há pròpriamente um sistema tributário nacional. Não se ignora que tal foi o desejo dos autores da emenda constitucional $n^{0} 18$, fonte primeira dêsse texto normativo. Êsse desejo, entretanto, não se traduziu em realidade, muito embora esteja hoje mais próximo de realizar-se do que antes. O Brasil persiste sendo uma federação e seus municípios mantêm a sua autonomia. Cada qual tem o seu sistema tributário, fixado, em maior ou menor escala, pelo seu legislador. $^{333}$

Prossegue ainda:

(...) o que se alcançou efetivamente, com a chamada reforma tributária consubstanciada inicialmente na emenda constitucional $\mathrm{n}^{0} 18$ - foi uma certa integração do sistema financeiro nacional e não a almejada unificação do sistema tributário. E isto tem seus aspectos positivos e benéficos, inquestionavelmente. ${ }^{334}$

$\mathrm{Na}$ visão do autor, a unificação do sistema tributário só ocorreria no Brasil, à semelhança da França ou da Itália, se apenas ao legislador federal coubesse legislar sobre a matéria. Se a repartição de tributos não fosse rígida, exclusiva e privativa. ${ }^{335}$ Para Geraldo Ataliba, o sistema tributário de 1967, assim como nas constituições brasileiras anteriores, estabelece dois tipos de competência tributária: a comum e a privativa.

A comum concerne às exações vinculadas a uma contraprestação do Estado, como no caso das taxas, contribuições de melhorias e a contribuição previdenciária. Já a competência privativa é a que concerne aos impostos, cuja competência exclusiva está expressamente determinada, caso a caso, na constituição. ${ }^{336}$

Apesar da polêmica sobre os limites da reforma, fato é que o sistema erigido pela emenda constitucional $\mathrm{n}^{\circ} 18$, consolidado na constituição de 1967 , buscou limitar a competência legislativa de estados e municípios ao máximo, ainda que não tenha logrado unificar o sistema tributário brasileiro que era sua meta.

${ }^{333}$ ATALIBA, Geraldo, op. cit., p. 223.

${ }^{334}$ Ibidem, p. 227.

${ }^{335}$ Ibidem, pp. 223/224.

${ }^{336}$ Ibidem, pp. 209/210. 


\subsection{3 - Código Tributário Nacional}

A promulgação da Lei 5.172/66, o código tributário nacional, foi sem dúvida o desfecho da reforma fiscal promovida pelos militares, embora alguns ajustes ainda viessem a ser realizados na constituição de 1967. Apesar de sua entrada em vigor ser peça chave para se concluir o projeto de criação de um único sistema tributário brasileiro, não mais subordinado às subdivisões administrativas da federação, não se pode concebê-lo como obra exclusiva do regime militar.

Sua elaboração remonta aos debates no Congresso Nacional, que datavam do final da $2^{\text {a }}$ Guerra Mundial. Recorda-nos, Aliomar Baleeiro, que o congresso jurídico, em comemoração ao centenário do Instituto dos Advogados, em 1943, já registrava a indicação favorável à codificação do direito financeiro brasileiro, o que viria a anteceder e influenciar a adoção pela constituição de 1946, em seu artigo $5^{\circ}$, da competência privativa da legislação federal para tratar da matéria. ${ }^{337}$

Embora a ideia de elaboração de um código tributário nacional já estivesse em discussão no congresso nacional, foi apenas em 1953, quando Oswaldo Aranha, então Ministro da Fazenda, solicitou ao Professor Rubens Gomes de Sousa a elaboração de um projeto, que a proposição ganhou forma. ${ }^{338}$

O Governo Vargas chegou a enviar o projeto elaborado pela comissão de juristas coordenada pelo ministério da fazenda ao congresso nacional, porém sua tramitação acabou não progredindo no período. Somente após o golpe militar que Rubens Gomes de Sousa juntamente com Gilberto Ulhoa Canto seriam convidados a assessorar na elaboração do projeto de código tributário nacional - bem como da emenda constitucional $\mathrm{n}^{\mathrm{0}} 18$ - e que o trabalho realizado em 1953 seria resgatado. ${ }^{339}$

Do ponto de vista federativo, não resta dúvida de que o principal problema a que o código viria sanar era o de unificar as regras de direito tributário e consolidar a restrição de estados e municípios legislarem sobre a matéria. Isso, pois, a despeito da previsão constitucional de 1946, de que a matéria era de incumbência federal, era

\footnotetext{
${ }^{337}$ BALEEIRO, Aliomar, op. cit., pp. 7 e 16. Muito embora, como também destaca o autor, houvesse opositores a ideia, como o caso do Deputado Marsagão, catedrático de direito administrativo da Faculdade de Direito de São Paulo, que temia a autonomização da matéria em face do direito administrativo.

${ }^{338}$ Ibidem, p. 9.

${ }^{339}$ Idem.
} 
extremamente comum no país que cada estado e município tivesse regulações diversas acerca dos prazos de prescrição, regras de solidariedade, bases de cálculo de seus impostos e conceito de fatos geradores, ${ }^{340}$ bem como os conceitos de taxa ${ }^{341}$ e os limites de competência fossem dilatados conforme os interesses daqueles que o interpretavam.

Nesse sentido, logo no Título I do Livro primeiro, nos artigos $2^{\circ}, 3^{\circ}, 4^{\circ}$ e $5^{\circ}$, o CTN busca delimitar a natureza jurídica dos tributos pelo fato gerador e não mais nas definições legais do mesmo ou de sua destinação. Registrando, ainda, o que seria a teoria tripartida dos tributos, segundo a qual existiriam apenas 3 espécies tributárias: impostos, taxas e contribuições de melhoria.

Divido em dois livros, o primeiro cuidava das disposições sobre o sistema tributário nacional, aprofundando em detalhes o sistema arquitetado pela emenda constitucional $\mathrm{n}^{\mathrm{o}} 18$ de 1965 e o segundo sobre as normas gerais de direito tributário, que seguem em vigor com pouquíssimas alterações até o presente momento. Seu mérito principal foi, como já dito, racionalizar o sistema construindo regras comuns para o funcionamento de todo direito tributário brasileiro.

Também coube ao código estabelecer de forma mais detalhada os pormenores da aplicação da legislação tributária em todo o país, consolidando os conceitos jurídicos acerca das espécies tributárias, os fatos geradores dos impostos, as regras de prescrição e os pormenores da relação tributária, do crédito tributário, o lançamento e a administração tributária.

Além disso, o CTN foi responsável por institucionalizar um novo padrão de administração tributária, prevendo mecanismos para a fiscalização tributária e para o processo administrativo de cobrança tributária, inclusive com os marcos para a cooperação entre união, estados e municípios nessa área.

O código tributário nacional é o elo de fechamento do sistema tributário único, porque comungou, entre todos os entes da federação, uma legislação comum que regeria as relações tributárias entre si, com os contribuintes e com a sociedade de maneira geral. Um efeito muito relevante disso, que por vezes passa despercebido, é o

\footnotetext{
${ }^{340}$ Ibidem, p. 11.

${ }^{341}$ Para ver um mapeamento da jurisprudência nos conflitos, ver: BALEEIRO, Aliomar. op. cit.1970, p. 23.
} 
fato de o CTN permitir o controle efetivo das políticas tributárias dos estados e municípios, ao levar para órbita da justiça federal os conflitos tributários locais.

Ele abre caminho para que se consolide uma jurisprudência tributária nacional controlando o exercício da capacidade tributária ativa dos estados e municípios. Portanto, não é apenas o código que regula as relações do Estado com os contribuintes, mas que instrumentaliza o pacto do federalismo fiscal brasileiro.

Apesar de ter vivido a mudança da ordem constitucional por três vezes, o código tributário brasileiro seguiu em vigor, sendo recepcionado pelas novas ordens jurídicas que marcaram novas fases da vida política brasileira, apesar de ter sido revogado em muitas partes, no que concerne à organização do sistema tributário, seu livro primeiro. Traço este que denota a profundidade dos arranjos envolvidos na reforma tributária de 1966 e o quanto, sobretudo na perspectiva federativa, o sistema continua sendo regido pelas mesmas bases. 


\section{3 - Reequilíbrio Federativo: Dependência Jurídica com}

\section{Autonomia Econômica}

\subsection{1 - Constituição de 1988 e Fragmentação do Modelo}

O debate sobre o sistema tributário na constituinte de 1987 se destacou pela proeminência da disputa federativa, ${ }^{342}$ enquanto temas como a equidade fiscal foram sobrestados para um momento posterior, o que acabou delegando aos legisladores derivados a tarefa de enfrentá-los um dia. ${ }^{343}$ Muito embora a questão da progressividade tenha encontrado alguma notoriedade na previsão de um imposto sobre grandes fortunas e no acolhimento de princípios gerais, ${ }^{344}$ a estrutura tributária permaneceu pouco alterada no que concerne às fontes de arrecadação.

Ainda, no aspecto distributivo, algumas mudanças voltadas para as garantias dos contribuintes repercutiram positivamente sobre a equidade do sistema. Um exemplo disso foi a previsão do princípio da isonomia (artigo 150, inciso II), o que abriu caminho para expansão da arrecadação do Imposto de Renda sobre a tabela progressiva para aplicações financeiras e setores do funcionalismo público anteriormente resguardados dela. ${ }^{345}$

No mesmo sentido, a previsão de revisões periódicas pelo Congresso Nacional dos incentivos fiscais existentes, a disposição explícita acerca da progressividade do IPTU também criavam condições para que viessem a ser promovidas mudanças de perfil equitativo na divisão social do ônus tributário. ${ }^{346}$ De certa forma, poder-se-ia ter uma

\footnotetext{
${ }^{342}$ BERCOVICI. Gilberto, op. cit., p. 64.

${ }^{343}$ OLIVEIRA, Fabrício Augusto. Crise, Reforma e Desordem do Sistema Tributário Nacional. Campinas: Editora UNICAMP, 1995, p. 70.

${ }^{344}$ Exemplos disso é o $\S 1^{\circ}$ do artigo 145 que estabelece: “§ $1^{\circ}$ - Sempre que possível, os impostos terão caráter pessoal e serão graduados segundo a capacidade econômica do contribuinte, facultado à administração tributária, especialmente para conferir efetividade a esses objetivos, identificar, respeitados os direitos individuais e nos termos da lei, o patrimônio, os rendimentos e as atividades econômicas do contribuinte."

${ }^{345}$ OLIVEIRA, Fabrício Augusto de, op. cit., p. 131.

${ }^{346}$ Há que se frisar que no caso do IPTU, contudo, o entendimento do judiciário - consolidado na súmula 668 do STF - sempre foi de que a única progressividade cabível era somente a relativa a utilização da propriedade. O imóvel subutilizado poderia, com o tempo, ter seu IPTU majorado em razão de sua produtividade. A progressividade que levava em conta a localização, valor e uso - a função social da propriedade de modo mais amplo - só se torna possível após a aprovação da emenda constitucional 29/2000 que prevê expressamente essas hipóteses na Constituição.
} 
perspectiva otimista com as mudanças promovidas pela Constituição de 1988, na medida em que elas criavam as bases para a construção de um sistema tributário mais progressivo no país.

A grande novidade foi a fusão de seis impostos - ICM, ISTR, ISC, IULC, IUEE e IUM - em torno do novo ICMS que passaria à competência dos Estados. Na proposta original incluiria também o ISS municipal, que seria extinto, mas essa inclusão não se logrou vitoriosa na constituinte. ${ }^{347}$ Outra polêmica girava em torno da cobrança do imposto na origem ou no destino dessas atividades, tendo prevalecido o princípio da origem, excetuadas as operações sobre combustíveis, petróleo, derivados e energia elétrica.

Seu maior impacto se dava na repactuação do federalismo fiscal que ela promovia. No que concerne a arrecadação tributária, o gráfico a seguir ilustra a participação dessa base fiscal ampliada no volume arrecadado pelo imposto atualmente.

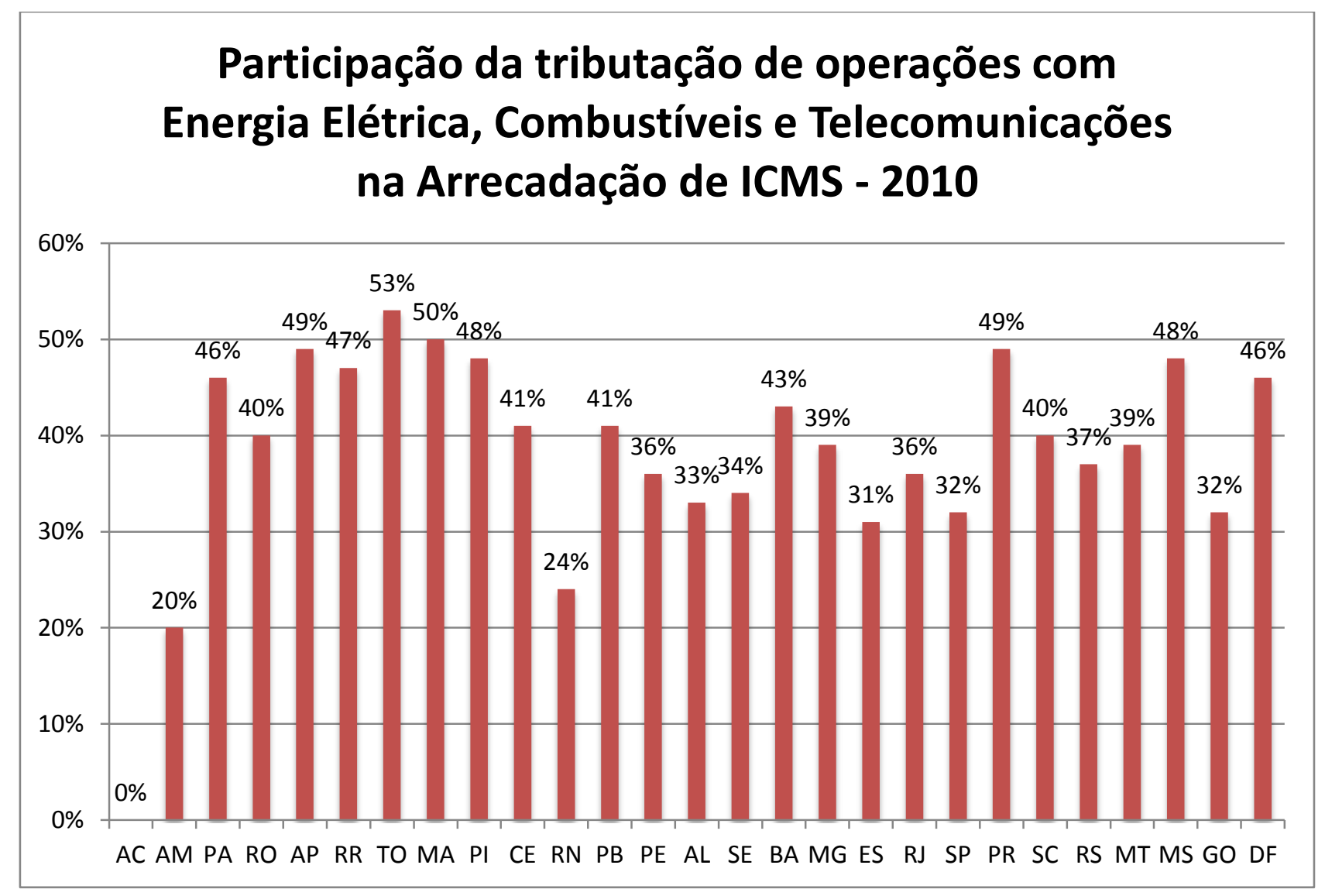

Gráfico elaborado com dados da Secretaria do Tesouro Nacional (STN), do Ipeadata, da Comissão

${ }^{347}$ OLIVEIRA, Fabrício Augusto de, op. cit. 1995, p. 80. 
Técnica Permanente do Confaz (Cotepe/Confaz) e das secretarias de Fazenda ou Finanças dos Estados e do Distrito Federal. Extraído de Rezende, Fernando. ICMS: Gênese, Mutações, Atualidade e Caminhos para Recuperação. Pg, 19.

O principal efeito, contudo, é que ao se fundir o antigo ICM (imposto sobre a circulação de mercadorias) com os impostos especiais federais sobre energia elétrica, minerais, combustíveis e lubrificantes, e transportes e comunicações, para além da ampliação da base fiscal, acabava-se criando uma espécie de sistema tributário estadual dentro de um robusto novo imposto.

Afora a aparente simplificação promovida, os vários regimes adotados para cobrança e administração do ICMS fizeram dele um imposto complexo e sem identidade. A depender da natureza da atividade, do grau de concentração da produção e o do tamanho da empresa, o ICMS pode se apresentar como um imposto sobre o valor adicionado, um imposto monofásico sobre a produção de bens, um imposto sobre a produção industrial, um tributo sobre vendas de pequenas e microempresas ou até uma espécie de tarifa aduaneira aplicada à entrada de produtos de outros Estados em vendas interestaduais. $^{348}$

Portanto, aparentemente, os Estados saiam duplamente fortalecidos, pois passavam a contar com um imposto com forte propensão de arrecadação, para geração de recursos próprios, e acabavam inserindo-se na gestão da política fiscal ao lhes ser permitido atuar sobre a tributação de todas essas atividades econômicas.

Com o ICMS, qualquer proposta de alteração na tributação sobre energia elétrica, combustíveis, minerais e comunicações passava a ter de ser pactuada com os 26 estados e o Distrito Federal. Mais do que isso, a cobrança desse imposto pelo princípio da origem também fazia com que os estados tivessem influência sobre a importação e exportação de mercadorias, uma vez que se recolhia o imposto antecipadamente. Passava a ser possível a coexistência de 27 cargas tributárias distintas sobre essas atividades no país.

${ }^{348}$ REZENDE, Fernando. ICMS: Gênese, Mutações, Atualidade e Caminhos para Recuperação. Brasília: IDP e FGV Projetos. vol 2., pp. 17 e 18. 
Outra medida foi impedir expressamente a União de conceder incentivos fiscais de impostos estaduais e municipais, bem como permitir que os Estados pudessem fixar as alíquotas internas de ICMS. ${ }^{349}$

Uma tentativa de harmonizar essas possíveis disparidades foi atribuir competências específicas ao Senado Federal para estabelecer alíquotas máximas e mínimas de ICMS para dirimir disputas regionais e fixar alíquota incidente sobre operações interestaduais e de exportação.

Outra medida foi manter em vigor as amarras à concessão de benefícios de ICMS impostas pela Lei Complementar $n^{0}$ 24/1975, que exigia a celebração de convênio entre os estados para tanto. No entanto, essas prerrogativas do Senado Federal e do CONFAZ - de controlar alíquotas e leis de incentivo fiscal - se revelariam muito restritas diante das possibilidades dos estados adotarem distintas políticas tributárias por meio da competência legislativa sobre o imposto, a ponto das disparidades terem levado a um quadro que ficou consagrado com o nome de "guerra-fiscal". 350

O reequilíbrio do federalismo realizado em 1988 ainda incluía a criação de um adicional de IR de 5\% para os estados - que seria revogado em 1993 - bem como a competência para instituir taxas e contribuições de melhorias, antes vedadas pela constituição. $^{351}$

Tomando esse quadro, percebe-se que a metodologia desse reequilíbrio federativo foi manter o sistema tributário nacional e unificado, criado na década de 1960, mas transferindo aos estados e municípios uma fatia muito mais relevante desse sistema tributário. Fato esse que resultou em uma interdependência jurídica dos entes da federação - uma vez que os freios do sistema anterior seguiam em vigor - mas com uma autonomia econômica, em face do aumento do percentual da carga tributária repartido com estados e municípios.

Se com as reformas da década de 1960 o governo federal foi o grande vencedor, em termos de concentração de recursos e competências tributárias, a constituinte de 1988 o

${ }^{349}$ AFONSO, José Roberto. A Questão Tributária e o Financiamento dos Diferentes Níveis de Governo. In: ÁlVAREZ AFFONSO, Rui Britto; e BARROS SILVA, Pedro Luiz. (orgs.). A Federação em Perspectiva: Ensaios Selecionados. São Paulo: Fundap, 1995, p. 320.

${ }^{350}$ Para um panorama das técnicas utilizadas pelos Estados na concessão de benefícios de ICMS, no contexto da guerra fiscal, ver: FIGUEIREDO, Ademir Picanço de. Conflito Fiscal Federativo: Os incentivos dos Estados na Jurisprudência do STF. Belém: Universidade Federal do Pará. Dissertação de Mestrado, 2007, p. $60-67$.

${ }^{351}$ OLIVEIRA, Fabrício Augusto de, op. cit., p. 114. 
sagrou como o grande derrotado. As mudanças, no entanto, se deram apenas na posição dos termos da equação, posto que o perfil geral das fontes de arrecadação seguiu o mesmo. Exceção feita para diversificação das fontes de financiamento da seguridade social, anteriormente adstritas à folha de salários e que passara a incorporar o faturamento e o lucro das empresas. ${ }^{352}$

Se a atuação extrafiscal do Estado também foi um instrumento central da política econômica brasileira até 1988 , ela passaria a ser um grande problema a partir da redemocratização. Isso porque o modelo implementado com o PAEG era o de concentrar na união a capacidade de intervenção econômica por meio da tributação e relevar aos estados e municípios mera participação na renda derivada dos tributos. Quadro esse que se altera por completo após a constituição de 1988, ao se garantir a eles autonomia fiscal e capacidade de intervenção extrafiscal sobre o domínio econômico com impacto na política fiscal nacional.

\subsection{2 - As Tentativas de Reforma}

Poucos anos após a promulgação da Constituição de 1988, o tema da reforma fiscal já se intensificou. As soluções encontradas pelos entes da federação para viabilizarem seu financiamento, diante da repactuação do federalismo fiscal firmada na constituinte, levaram a graves distorções econômicas.

A primeira delas decorria de que a União, “derrotada" pelos estados e municípios na repartição de receitas tributárias, teria reagido a seu déficit financeiro por meio do aumento de alíquotas e da criação de contribuições sociais com incidência cumulativa, como o caso do PIS, da CSLL e do Finsocial. ${ }^{353}$ Sem a necessidade de partilhar suas receitas e com competência exclusiva para instituí-las, ${ }^{354}$ a União teria encontrado nelas a saída perfeita para recompor seu orçamento (pressionado pelas demandas de investimento que lhe foram incumbidas pela própria constituição).

\footnotetext{
${ }^{352}$ Ibidem, p. 105.

${ }^{353}$ Ibidem, p. 141. “Após o fracasso da criação do selo-pedágio, que acabou considerado inconstitucional pela justiça, criou-se a Contribuição sobre o Lucro das Empresas em 1989 para financiamento da previdência, aumentou-se a alíquota do Finsocial, que passou de 0,5\% em 1988 para 2\% em 1990, alterou-se a forma de cobrança do PIS e lançou-se mão do IOF com ênfase a partir do governo Collor para taxação dos ativos financeiros da economia."

${ }^{354}$ Com fundamento na reserva constitucional, prevista nos artigos 149 e 195 da CF.
} 
Entretanto, as consequências extrafiscais do aumento da arrecadação por meio da criação de contribuições sociais conduziria ao esfacelamento do arranjo político e econômico que sustentara o sistema tributário brasileiro desenhado na constituinte.

No âmbito federativo, o impacto imediato dessas medidas foi uma nova centralização das receitas tributárias, contrariando a orientação adotada pela constituição tributária de 1988. É o que nos aponta o gráfico abaixo, demonstrando a composição da arrecadação tributária da união em 1989 e 1993 :

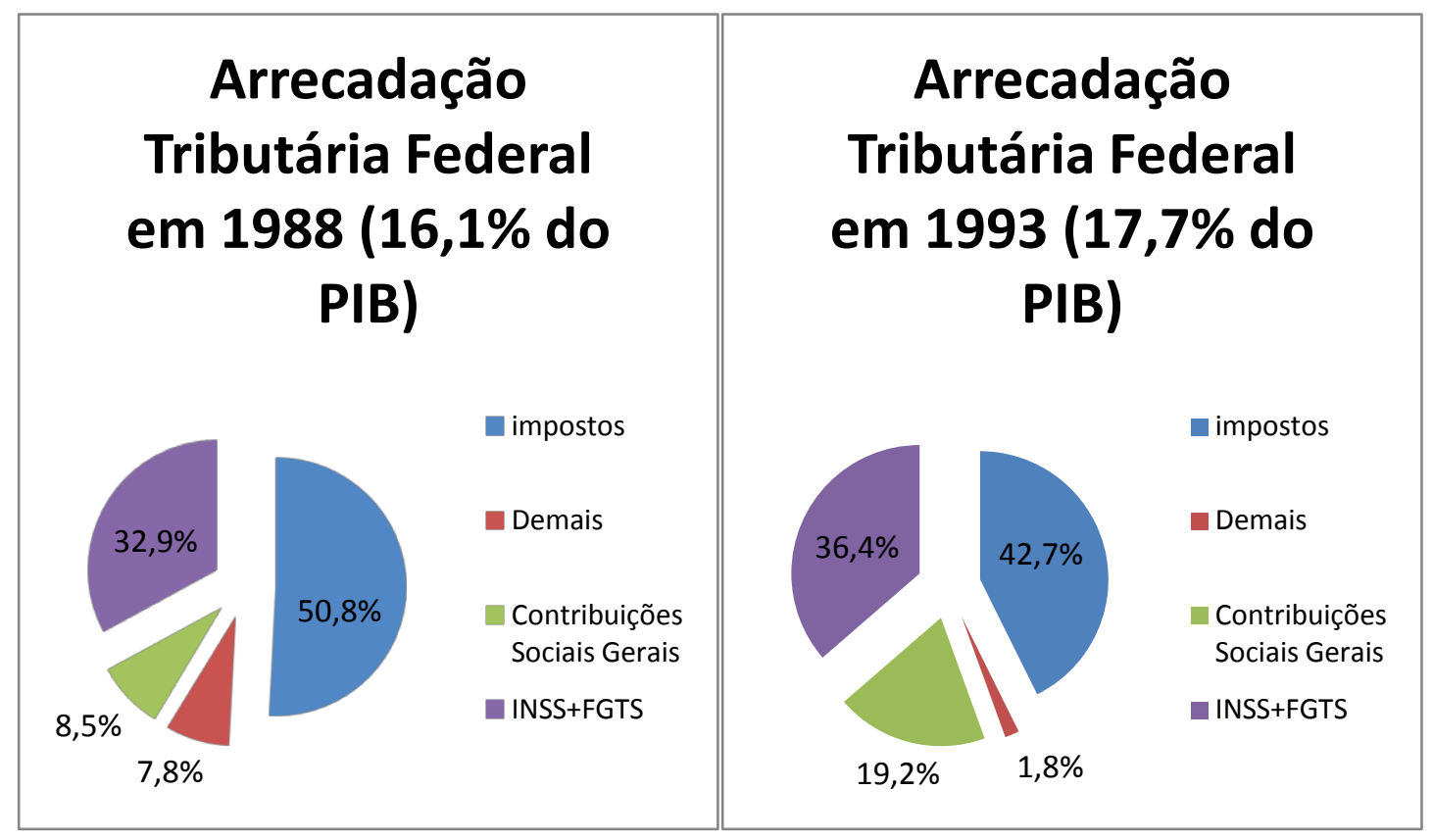

Fonte: REZENDE, Fernando; OLIVEIRA, Fabrício Augusto de e ARAUJO, Erika Amorim. O Dilema Fiscal: Remendar ou Reformar? Rio de Janeiro: FGV, 2007, p. 97.

Em termos econômicos, essa recomposição das receitas federais foi feita à custa de impactos negativos à eficiência do sistema. $\mathrm{O}$ efeito da incidência em cascata (devido a não incidir apenas sobre o valor agregado em cada etapa da produção, mas ao fim da cadeia) dessas contribuições implicaria em distorções nos preços e nos investimentos nacionais.

Ademais, a multiplicação de tributos de natureza indireta e regressiva, bem como a adoção de outras medidas que resultavam em aumento de receita, como a redução dos 
prazos de apuração e recolhimento de impostos, levou ao aumento da complexificação e da instabilidade do sistema. ${ }^{355}$

Dessa maneira, o quadro no início da década de 1990 já deflagrava a crise profunda da repartição tributária. Com vistas à janela de oportunidades para revisão constitucional prevista para outubro de 1993, pelo art. $3^{\circ}$ do ADCT da CF, algumas propostas de mudança começaram a surgir no Congresso Nacional. ${ }^{356}$

Embora essas propostas revelassem distintos pressupostos e leituras políticas sobre a função do sistema tributário e do papel do Estado, todas acabavam por convergir em torno de certos pontos como a necessidade de simplificação da legislação, a redução do número de tributos, a ampliação da base de arrecadação e a desoneração da produção nacional, principalmente os investimentos e as exportações. ${ }^{357}$

Apesar das iniciativas, as propostas acabaram ficando de lado em meio ao processo político que marcou o Governo Itamar Franco, entre o impeachment do presidente Fernando Collor de Mello e a implantação do Plano Real de estabilização monetária.

No início do Governo Fernando Henrique Cardoso, em meio a uma série de outras reformas planificadas por Propostas de Emenda à Constituição, enviadas ao Congresso (dentre as quais se destacam a Previdenciária, a Administrativa e a da Ordem Econômica), o governo federal enviou a PEC 175/1995 que reformava o sistema tributário.

O projeto final encaminhado ao congresso propunha a extinção do IPI e a criação de uma alíquota federal sobre a mesma base do ICMS, tornando-o um imposto sobre o valor agregado compartilhado entre as três esferas da federação. Nesse movimento, a PEC caminhava para unificar as regras de ICMS, estabelecendo sua cobrança na saída da mercadoria, dando competência ao Senado Federal para dispor sobre a destinação do produto do ICMS sobre operações interestaduais e prevendo que lei complementar iria sanar eventuais impasses não solucionados pelas mudanças constitucionais.

\footnotetext{
${ }^{355}$ OLIVEIRA, Fabrício Augusto de, op. cit., p. 142.

${ }^{356}$ OLIVEIRA, Fabrício Augusto de. A Lógica das Reformas: A Evolução do Sistema Tributário (19662002). In: BIASOTO JÚNIOR, Geraldo e PINTO, Márcio Percival Alves (orgs.). Política Fiscal $e$ Desenvolvimento no Brasil. Campinas: Editora Unicamp, 2006, p. 29. Segundo Fabrício Augusto de Oliveira cinco destas propostas merecem maior destaque: a do imposto único sobre transações, defendida pelo Deputado Flávio Rocha; a PEC n ${ }^{\circ}$ 48/1991, do Deputado Luís Carlos Hauly; a emenda substitutiva à PEC n ${ }^{\circ}$ 48/1991, de autoria do Deputado Luís Roberto Ponte; a emenda substitutiva à PEC n ${ }^{\circ}$ 48/1991, de autoria do Deputado Roberto Freire; e a proposta do Executivo, de autoria da Comissão coordenada por Ary Oswaldo Mattos Filho.

${ }^{357}$ Ibidem, p. 31.
} 
Como compensação pela perda de receita, decorrente da desoneração de ICMS das exportações que a PEC promovia, propunha passar o ITR da competência federal para a estadual. ${ }^{358}$ Por fim, a proposta ainda previa pequenas alterações no IPTU e no ISSQN, visando a solidificar o princípio da progressividade do primeiro e permitindo que a lei complementar definisse as alíquotas máximas e mínimas do segundo.

Entretanto, a sua tramitação não avançou no Congresso. Em parte pelos impasses que tamanha mudança colocava, mas também em função de o governo ter optado por não aguardar a tramitação da reforma mais ampla para promover mudanças consideradas mais urgentes, atacando-as por meio de alterações na legislação infraconstitucional.

Entre essas medidas, merece destaque a criação do regime tributário para micro e pequenas empresas - SIMPLES - através da Lei $n^{0}$ 9.317/1996 e, principalmente, a aprovação da Lei Complementar $n^{\circ}$ 8/1996 (Lei Kandir), que desonerou do ICMS as exportações de produtos primários, semielaborados e a aquisição de bens de capital. ${ }^{359}$

A questão fiscal se agrava em 1998, quando em decorrência da crise russa a economia brasileira é fortemente atingida. A nova estratégia de estabilização que se desenvolve a partir daí passa a se sustentar na geração de elevados superávits fiscais primários, o que teve impacto na gestão da política tributária, sobretudo com o aumento das alíquotas das contribuições sociais por parte da União. ${ }^{360}$

${ }^{358}$ Exposição de motivos da PEC 175/1995.

${ }^{359}$ REZENDE, Fernando; OLIVEIRA, Fabrício Augusto de e ARAUJO, Erika Amorim. O Dilema Fiscal: Remendar ou Reformar? Rio de Janeiro: FGV, 2007, p. 114.

${ }^{360}$ Ibidem, p. 130/131. 


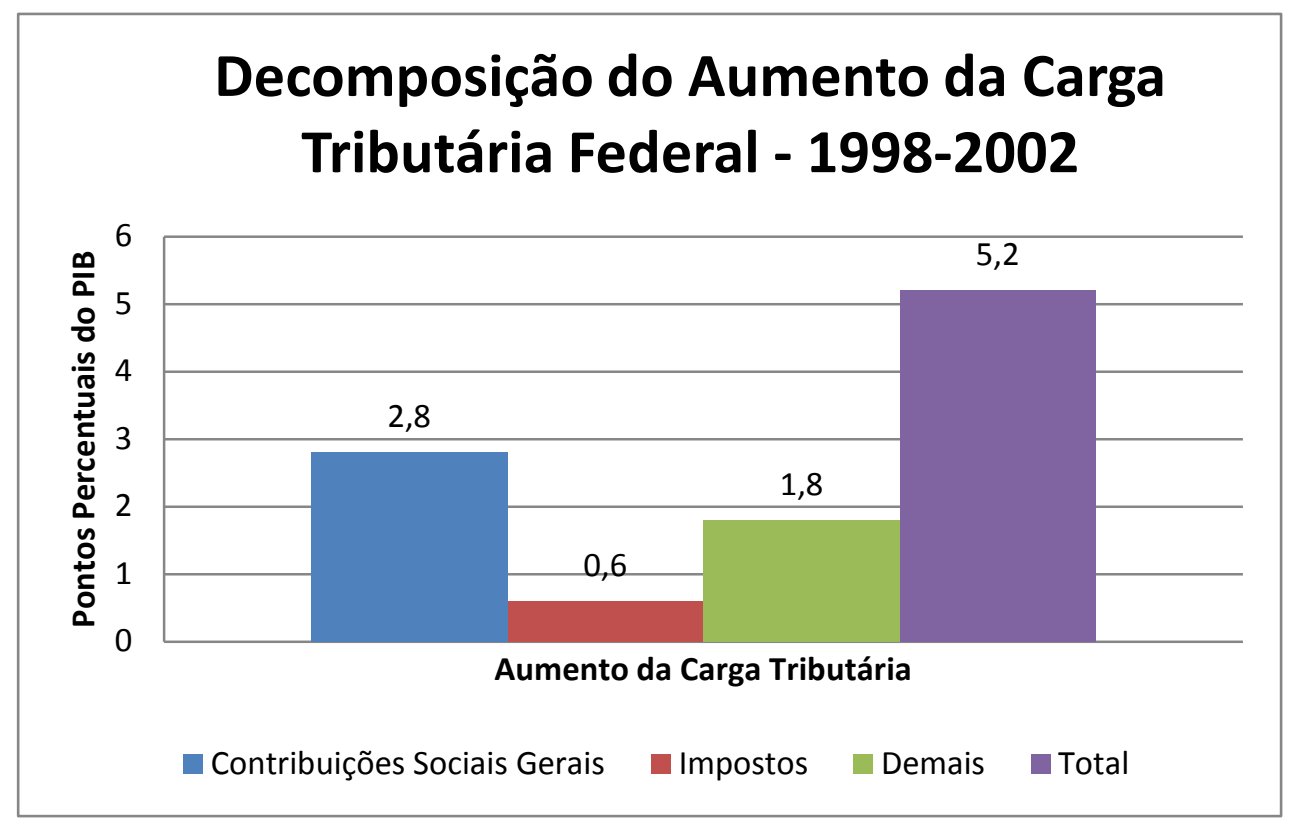

Fonte: REZENDE, Fernando; OLIVEIRA, Fabrício Augusto de e ARAUJO, Erika Amorim. O Dilema Fiscal: Remendar ou Reformar? Rio de Janeiro: FGV, 2007, p. 131.

Outras mudanças ocorridas no final do segundo mandato do governo FHC ainda mereceriam destaque, como a aprovação das emendas constitucionais $n^{0}$ 29/2000 e $n^{0} 32 / 2002$ que, entre outras medidas, previram, respectivamente, a possibilidade de adoção de alíquotas progressivas de IPTU em razão do valor do imóvel e sua localização, bem como a edição de lei complementar para fixar as alíquotas máximas e mínimas de ISS e regular a forma e as condições de concessão e revogação de isenções, benefícios fiscais e incentivos (de ISS) pelos municípios. Realizavam-se dessa forma as mudanças menos polêmicas previstas na PEC 175/1995.

No início do primeiro mandato do governo Lula, o Poder Executivo optou por enviar uma nova proposta de reforma para o Congresso Nacional (PEC 41/2003), ao invés de dar andamento a PEC 175/95 em tramitação na Câmara dos Deputados. ${ }^{361}$

A nova proposta tinha como objetivos centrais: federalizar a legislação do ICMS e reduzir a sua quantidade de alíquotas, transformar a CPMF em um imposto permanente

${ }^{361}$ Para maiores informações sobre esse substitutivo ler artigo de Erika Amorim e José Roberto Afonso: AFONSO, José Roberto Rodrigues e ARAÚJO, Erika Amorim, Pós-constituinte e Impostos Indiretos: Deformar ou Reformar? In: BIASOTO JÚNIOR, Geraldo e PINTO, Márcio Percival Alves (orgs.). Política Fiscal e Desenvolvimento no Brasil. Campinas: Editora Unicamp, 2006. 
e extinguir parcialmente a cumulatividade da COFINS - a espelho do que havia sido feito com o PIS em 2002. ${ }^{362}$

Ao final, aprovada sob a forma da emenda constitucional 42/2003, a reforma restringiu-se à prorrogação da CPMF, à criação da CIDE-Combustíveis (com arrecadação compartilhada com Estados e Municípios) e à desoneração da folha de salários. A extinção da cumulatividade da COFINS foi realizada pelo governo por meio de Medida Provisória, convertida na Lei $\mathrm{n}^{0}$ 10.833/03. Além disso, previa a competência do Senado Federal para estabelecer alíquotas mínimas de IPVA, bem como sua possível utilização de alíquotas progressivas em função do tipo de utilização.

Como destaca a professora Sulamis Dain, em ambos os governos (FHC e Lula) a necessidade do ajuste fiscal de curto prazo se sobrepôs à dificuldade de reformas mais profundas e estruturais. ${ }^{363}$

Em seu segundo mandato, o governo Lula apresentou uma nova tentativa de reforma tributária. Elegeram-se significativos desafios para dar racionalidade ao sistema como: reduzir o número de tributos e o custo do cumprimento das obrigações acessórias, simplificar procedimentos, eliminar distorções e desonerar investimentos e a folha de trabalho.

O diagnóstico da reforma proposta era que o cerne dos problemas se encontrava na tributação indireta e as saídas possíveis estariam: na criação de um imposto chamado IVA-F (englobando a atual COFINS, a contribuição para o PIS, a CIDE-Combustíveis, a Contribuição sobre a folha para o Salário Educação); na criação de um "novo ICMS" com a mesma abrangência do anterior, porém com uma sistemática nacional de definição das alíquotas na qual o Senado Federal ganharia maior papel de destaque na organização das mesmas; e na extinção da CSLL e sua posterior fusão ao IRPJ.

O projeto, no entanto, não avançou e segue, até o presente momento, em tramitação na Câmara dos Deputados.

No Governo Dilma, iniciado em 2011, a estratégia de condução da reforma tributária parece ter se alterado. Em vez de uma negociação em conjunto de uma ampla

\footnotetext{
${ }^{362}$ Pra uma visão mais detalhada da proposta e seu andamento ver: DAIN, Sulamis. A Economia Política da Reforma Tributária de 2003. In: BIASOTO JÚNIOR, Geraldo e PINTO, Márcio Percival Alves (orgs.). Política Fiscal e Desenvolvimento no Brasil. Campinas: Editora Unicamp, 2006.

363 Idem.
} 
reforma, o governo optou pelo envio de alguns projetos de reformas pontuais do sistema tributário, numa estratégia que foi chamada de reforma tributária fatiada. ${ }^{364}$

Dentre as principais frentes dessa reforma fatiada, merece destaque - até o momento em que essa dissertação é escrita - a aprovação da Resolução do Senado Federal $n^{\circ} 13 / 2012$, que entrará em vigor a partir de $1^{\circ}$ de janeiro de 2013 , fixando em $4 \%$ a alíquota de ICMS incidente sobre operações interestaduais com produtos importados.

A medida objetiva atacar um ponto bem específico da guerra-fiscal, a chamada "guerra dos portos." Alguns estados, com alta atividade portuária, passaram a conceder benefícios de ICMS para que importadores optassem por ingressar com seus produtos por seus portos, incentivando sua atividade portuária. Ocorre que esses incentivos acabavam por reduzir a carga tributária incidente sobre os produtos importados frente aos produtos nacionais do mesmo gênero.

A sistemática dos incentivos era a seguinte: ao ingressarem no país, o estado de ingresso da mercadoria importada aplicava a alíquota interestadual de ICMS, que pode variar de $7 \%$ a $12 \%$, a depender do estado de saída e de chegada da mercadoria. ${ }^{365}$ Ao receber a mercadoria como destino final, o Estado consumidor aplicava o diferencial de alíquota (alíquota da mercadoria - alíquota interestadual), deduzindo, assim, os percentuais de ICMS já recolhidos no estado que realizou a importação.

Esse valor, entretanto, acabava sendo menor do que o registrado, pois os estados que concediam incentivos fiscais recolhiam um valor muito inferior ao que corresponderia a alíquota interestadual. Porém, ao chegarem ao estado de destino final do produto, os importadores se creditavam do valor "cheio" da alíquota interestadual, como se a tivessem recolhido integralmente.

Dessa maneira, supondo que um mesmo produto tivesse uma alíquota de $17 \%$ de ICMS, quando importado acabava por recolher uma alíquota real entre 5\% e $10 \%$ de ICMS.

Embora aparentemente simples, a medida consumiu todo o primeiro ano do governo, sendo que sua tramitação era praticamente sumária, uma vez que a mesma só precisava ser aprovada no plenário do Senado Federal, sem passar pela Câmara ou por

${ }^{364}$ WATANABE, Marta. Economistas divergem sobre estratégia de fazer uma reforma tributária "fatiada". Valor Econômico, São Paulo, 30 de outubro de 2012. 1 cad. página A2.

${ }^{365}$ Esses patamares são hoje regulados pela resolução do Senado Federal no 22/89. 
apreciação de veto presidencial. Fato que revela um pouco a dificuldade de se promover ajustes coordenados no sistema federativo fiscal.

Há recentes sinalizações de que novas resoluções nesse sentido possam vir a ser aprovadas para outros tipos de produtos, promovendo-se, gradualmente, uma verdadeira transição para um regime de cobrança de ICMS no destino. ${ }^{366}$

É perceptível que nesse curto período histórico há uma tendência cada vez maior de redução da amplitude das propostas de reformas. Em que pesem as diferenças políticas que marcam as distintas administrações, sucessivamente, os objetivos dos projetos de reforma tributária foram se reduzindo diante da dificuldade de êxito junto ao Congresso Nacional.

Se por um lado os objetivos extrafiscais da tributação brasileira motivam ajustes centrípetos, que apontem para uma maior simplificação do sistema, centralização tributária e concentração da política fiscal, por outro lado a crise físcal dos entes subnacionais ${ }^{367}$ motivam ajustes centrífugos que apontem para o aumento de seus recursos e de sua autonomia financeira, o que implicaria necessariamente em complexificação do sistema e descentralização da política fiscal. A força resultante da soma destes vetores tende a zero, o que acaba por prorrogar os impasses desta tensão como: a guerra fiscal entre os estados, o alto custo para se pagar os impostos e a falta de racionalidade do sistema.

Ainda assim, mesmo as primeiras tentativas de reformas mais abrangentes do sistema não logravam ser profundas e estruturais. Procurava-se na verdade propor ajustes de rumo que não ameaçassem diminuir a arrecadação e não alterassem significativamente a atual distribuição de competências tributárias. A base da estrutura tributária brasileira seguiria apoiada sobre a tributação indireta sobre bens e serviços e a tendência predominante é de concentração dos instrumentos de política fiscal sob a tutela da União.

De uma forma geral todas as tensões guardam relação com a função exercida pela estrutura tributária no regime de acumulação capitalista brasileiro e, nesse sentido, a

\footnotetext{
${ }^{366}$ WATANABE, Marta. Economistas divergem sobre estratégia de fazer uma reforma tributária "fatiada". Valor Econômico, São Paulo, 30 de outubro de 2012. 1 cad. página A2.

${ }^{367}$ Para uma visão mais detalhada dessa crise ver: LOPREATO, Francisco Luiz Caseiro. O Colapso das Finanças Estaduais e a Crise da Federação. São Paulo: UNESP, 2002.
} 
dificuldade atual de construção de ajustes e reformas do sistema se explica, parcialmente, pela falta de um consenso em torno dessas tensões. 


\section{CONCLUSÃO}

\section{Separar a Fiscalidade e a Extrafiscalidade Tributária}

A tradição majoritária do pensamento jurídico tem sido tratar a extrafiscalidade como a outra face da tributação. ${ }^{368}$ Uma face não propriamente jurídica, em geral muito pouco conhecida pelo direito, dos efeitos econômicos sociais e políticos decorrentes da imposição de normas tributárias. ${ }^{369}$ Uma decorrência natural do poder de tributar, ${ }^{370}$ desde os primórdios da tributação, que com a revolução keynesiana na teoria econômica passou a ganhar uma utilização crescente. ${ }^{371}$

Entretanto, a revolução keynesiana na teoria econômica também intensificou a prescrição de políticas públicas anticíclicas que alteraram o padrão normativo do direito ao longo do século XX. A relação entre direito e economia foi redescoberta, diante da instrumentalização do direito para organizar o mercado e manipular a economia em busca de finalidades políticas, ${ }^{372}$ o que levou a uma progressiva constitucionalização de princípios, regras e finalidades econômicas para dirigir essa manipulação estatal do processo econômico.

Nesse contexto, a dimensão extrafiscal da tributação emerge enquanto finalidade alocativa, distributiva ou estabilizadora de intervenção do Estado sobre o domínio econômico, por indução, oneratória ou desoneratória.

De tal modo que não faz sentido, nos dias de hoje, tratá-la como uma finalidade não pertinente ao conhecimento jurídico, pois a intervenção econômica do Estado é constitucionalmente determinada, regulamentada e limitada.

O formalismo dessa visão é de tamanho paroxismo que ao afastar de seu campo de análise a finalidade regulatória da tributação, por considerar que seu emprego decorre

\footnotetext{
${ }^{368}$ BECKER, Alfredo Augusto, op. cit., p. 633.

${ }^{369}$ CARVALHO, Paulo de Barros. op. cit.1976, p. 32/ 38.

370 A esse respeito, Geraldo Ataliba assevera: "355 - Na verdade, o instrumento tributário está na disponibilidade daquele legislador que tem competência para usá-lo. Quer dizer: conferindo a Constituição ao Legislador ordinário certa faixa de competência, em matéria tributária, usará êle, a seu alvedrio, dos institutos nela compreendidos, para os fins que deseje, desde que juridicamente consentidos." In: ATALIBA, Geraldo. op. cit.1968, p. 165.

${ }^{371}$ DEODATO, Alberto. op. cit. 1949, p. 146.

${ }^{372}$ BERCOVICI, Gilberto. op. cit. 2009, p. 518.
} 
da discricionariedade econômica do poder de tributar, legitima qualquer efeito econômico produzido pela tributação com finalidade arrecadatória.

Se não competir ao conhecimento jurídico analisar os efeitos econômicos, sociais e políticos produzidos pela tributação, como então saber se ela produz ou não efeito confiscatório (art. 150, inciso IV, da CF)? Como evitar que por meio de tributos interestaduais ou intermunicipais se estabeleça limitações ao tráfego de pessoas e bens (art. 150, inciso $\mathrm{V}$, da $\mathrm{CF}$ ), se não pela análise de seus efeitos?

Tampouco faz sentido abordá-la como uma dimensão acessória à finalidade fiscal de arrecadar recursos para o Estado, ou a ela subordinada. Seja pela perspectiva econômica, histórica, ou normativa, o que se observa é a constante tendência à separação entre o regime jurídico da fiscalidade e da extrafiscalidade, cuja única semelhança segue sendo o fato de serem veiculadas pelo mesmo instrumento.

Sob ângulo da racionalidade econômica, a coordenação da política fiscal é um imperativo que tende, invariavelmente, à centralização das funções distributivas e estabilizadora.

Tendo isso em vista, analisando os dilemas do sistema tributário brasileiro, José Roberto Afonso questiona como poderá a União formular e executar com eficácia a política macroeconômica se é desestimulada a ampliar o Imposto de Renda, em face do art. 159 da CF estabelecer a destinação de $48 \%$ de sua arrecadação para repartição com o FPE $(21,5 \%)$, o FPM $(23,5 \%)$, o FNE $(1,8 \%)$ e o FNO $(1,2 \%) ?^{373}$

Além disso, como poderá a União recorrer à política tributária para estabilização macroeconômica se não controla o imposto mais importante incidente sobre o mercado doméstico? Será possível que os governos subnacionais administrem e arrecadem o ICMS e o ISS de uma maneira que atendam a suas necessidades financeiras, atraiam investimentos e auxiliem na política de estabilização ${ }^{374}$

A própria evolução legislativa brasileira demonstra com clareza que uma das formas de tatear esses dilemas nacionais é atentar para a gradual separação entre a competência tributária e a capacidade de intervenção extrafiscal. As progressivas mudanças no modelo federativo da constituição de 1891 caminharam no sentido dessa cisão, cuja tendência atual é se aprofundar.

${ }^{373}$ AFONSO, José Roberto. op. cit., p. 322

${ }^{374}$ Idem. 
Gilberto Bercovici lembra que o federalismo adotado pela constituição de 1891, moldado à semelhança do federalismo dualista norte-americano, buscou de tal maneira garantir autonomia dos entes federados que acabou por restringir a cooperação entre eles a situações excepcionais, como de calamidade pública. ${ }^{375} \mathrm{Um}$ modelo que destoava não apenas do que era a relação unitária entre o Império e as Províncias, como também do que viria a ser a relação federativa entre União e Estados a partir da década de 1930 , com a progressiva adoção de um modelo de federalismo cooperativo. ${ }^{376}$ Uma ruptura com o passado e com o futuro.

Os estados se constituíam como espaços econômicos quase autárquicos, podendo legislar e tributar sobre o comércio exterior e interior, o que inviabilizou qualquer política econômica propriamente dita da União até a Revolução de $1930 .{ }^{377}$ Tendo-se clareza que nem mesmo o federalismo norte-americano adotou essa via, optando-se lá pela competência concorrente entre União e estados para criar tributos, admitindo-se a bitributação (exceto para o comércio exterior que fora reservado exclusivamente à União). ${ }^{378}$

Francisco de Oliveira o classificou como uma solução jurídica para acolher o status quo constituído pelas oligarquias regionais durante o Império. Uma ideia fora do lugar, ausente da tradição de pensamento nacional. ${ }^{379}$ Pois, diferentemente do que marca a construção do federalismo nos Estados Unidos ou na Europa - a afirmação de uma cidadania local, cultural e política - o anseio do federalismo no Brasil sempre esteve ligado às aspirações de desenvolvimento regional do país e à assimetria entre regiões decorrente da dependência econômica. ${ }^{380}$ Anseio esse que depende pouco ou nada da autonomia dos estados, mas $\operatorname{sim}$ da descentralização e redirecionamento dos investimentos.

Ademais, esse modelo de uma federação dualista e economicamente autônoma, foi ferido de morte com a integração dos mercados na década de 1930, que passa gradualmente a centralizar na União a política econômica do país. ${ }^{381} \mathrm{Em}$ um

\footnotetext{
${ }^{375}$ BERCOVICI, Gilberto. op. cit. 2004, p. 31.

${ }^{376}$ Ibidem, p. 23/ 31/ 39.

377 OLIVEIRA, Francisco de. op. cit., p. 80.

${ }^{378}$ HAMILTON, Alexander; MADISON, James; e JAY, John. O Federalista. Trad: Hiltomar Martins Oliveira. Belo Horizonte: Líder, 2003, p. 206 e 207.

${ }^{379}$ OLIVEIRA, Francisco de. op. cit., p. 76.

${ }^{380}$ FURTADO, Celso. O Longo Amanhecer: Reflexões sobre a Formação do Brasil. $2^{\text {a }}$ Ed. Rio de Janeiro: Paz e Terra, 1999, p. 46.

${ }^{381}$ OLIVEIRA, Francisco de. op. cit., p. 80.
} 
movimento que, da perspectiva dos instrumentos fiscais como o sistema tributário, simultaneamente concentra na União a capacidade de legislar e intervir na economia pela tributação e desconcentra - ainda que timidamente - a receita tributária da União para estados e municípios por meio de transferências verticais compensatórias dos Fundos Constitucionais. $^{382}$

Aprofundado ao limite com as reformas da década de 1960, houve uma transição definitiva desse modelo estanque de repartição de competências federativas para construção de um sistema tributário nacional compartilhado. Sistema esse que se estabelecia com a repartição da fiscalidade em troca da concentração da extrafiscalidade. O IPI e o IR passam a destinar parte de sua arrecadação para o Fundo de Participação dos Municípios (FPM) e para o Fundo de Participação dos Estados (FPE), com base em critérios como a extensão territorial e o coeficiente populacional de cada ente. ${ }^{383}$ Em contrapartida, os limites para fixação de alíquotas de ICM e de ISS passaram para órbita da União.

Uma estrutura cuja fisionomia geral foi mantida com a redemocratização e até ampliada em alguns aspectos, como argumenta Fernando Rezende. ${ }^{384}$ Se por um lado a reforma tributária de 1988 vedou à União conceder incentivos por conta de tributos estaduais e municipais, como fez em larga medida nos anos 1970, e ampliou enormemente a base de incidência do ICMS em relação ao ICM, por outro incorporou o sistema de limites à capacidade legislativa e tributária dos estados e municípios, visando dirimir potenciais conflitos de uma indesejada utilização extrafíscal de seus impostos e ampliou ao máximo as transferências intergovernamentais instituídas na década de $1960 .^{385}$

Da mesma forma, a repartição de competências concorrente para legislar sobre direito tributário, financeiro e econômico, segue no sentido do estabelecimento das regras gerais de intervenção extrafiscal pela União, cabendo aos Estados lhe suplementar e aos Municípios agir somente no que concerne aos interesses locais.

\footnotetext{
382 Ibidem, p. 81.

${ }^{383}$ Vide: arts. 86 à 91 do CTN. BRASIL. BRASIL. Lei n ${ }^{\circ} 5.172$, de 25 de outubro de 1966. Dispõe sobre o Sistema Tributário Nacional e institui norma gerais de direito tributário aplicáveis à União, Estados e Municípios. In: Vade Mecum Tributário e Financeiro. Florianópolis: Conceito, 2010. Organização do texto: João Batista Lazzari et al.

384 RESENDE, Fernando. O Financiamento das Políticas Públicas: Problemas Atuais. In: ÁLVAREZ AFFONSO, Rui Britto; e BARROS SILVA, Pedro Luiz. (orgs.). A Federação em Perspectiva: Ensaios Selecionados. São Paulo: Fundap, 1995, p. 246.

${ }^{385}$ Idem. Ver também: AFONSO, José Roberto. op. cit., p. 320.
} 
A lógica do federalismo fiscal brasileiro, portanto, apesar de algumas inflexões, é de não confundir a repartição de fontes tributárias exclusivas, e sua capacidade legislativa decorrente disso, com a capacidade extrafiscal de intervir regulatoriamente por meio destes tributos. Desde a década de 1930 foi operada uma transição em nosso sistema tributário que ruma para um modelo de federalismo cooperativo em que a característica central da repartição de competências é dada pelos artigos 22, 23, 24, 25 e 30 da constituição de 1988, elegendo as matérias a que incumbe a cada um dos entes da federação legislar de forma privativa, comum ou concorrente.

Dessa perspectiva, fenômenos como a guerra fiscal do ICMS no Brasil são claras deturpações do sistema tributário, em flagrante afronta à constituição. Da perspectiva jurídica não há dúvidas quanto à inconstitucionalidade destes benefícios. Boa parte deles consiste no manejo de incentivos concedidos por atos infralegais estaduais, mascarados por simulações jurídicas, que buscam driblar os limites da Lei complementar 24/1975, que estabelece a necessidade de unanimidade no CONFAZ para a provação de incentivos fiscais de ICMS. ${ }^{386}$

A ideia de que um ente incompetente para legislar sobre uma determinada matéria tenha competência para regulá-la por meio de seus tributos é de um instrumentalismo que não mais encontra ambiente face o direito constitucional positivo brasileiro. A busca por centralização na gestão da extrafiscalidade estabilizadora é inerente à racionalidade econômica e, inevitavelmente se imporá. As diversas tentativas de reformas tributárias constitucionais no período recente apontam nesse sentido.

Entretanto, na procura pela manutenção de uma pretensa autonomia federativa, ao modelo do federalismo norte-americano e do federalismo brasileiro da república velha, muitos ainda insistem em procurar uma repartição tributária equilibrada em que se encontre uma alternativa para transferir para União o controle da tributação sobre o consumo, realizada em parte pelo ICMS, garantindo aos Estados uma faixa de tributação alternativa que mantenha os níveis fiscais de arrecadação da circulação de mercadorias sem a sua capacidade de produzir os impactos extrafiscais regulatórios que a mesma produz.

Somos céticos quanto a essa via. Muitos diagnósticos e propostas recentes de reforma do sistema tributário, voltadas para questões como a diminuição da carga, a

\footnotetext{
${ }^{386}$ Para um mapeamento da guerra fiscal presente no STF por uma sucessão de Ações Diretas de Inconstitucionalidade, ver: FIGUEIREDO, Ademir Picanço de. op. cit., p. 67- 92.
} 
racionalização dos tributos ou o aumento da equidade geral da tributação, não conseguiram avançar porque não puderam oferecer garantias aos envolvidos de que eles não sairiam delas com menos recursos.

Pensamos que uma tendência promissora é aprofundar o federalismo cooperativo já inscrito na Constituição de 1988, separando ainda mais o debate das fontes de financiamento tributário do debate dos instrumentos de intervenção tributária.

É equivocado, porém, acreditar que o quadro normativo atual é suficiente para enfrentar esse conflito - que a experiência prática demonstra persistir - ou confiar ao STF a responsabilidade por dirimi-lo. Há uma série de possíveis inovações incrementais capazes de atenuar o problema, as quais nos permitimos apontar algumas.

Um primeiro passo possível é se caminhar rumo a um maior rigor contra as utilizações extrafiscais dos tributos estaduais e municipais que são diametralmente opostas a extrafiscalidade estabilizadora nacional.

Como não seria possível estabelecer dois regimes jurídicos para o tratamento da tributação de acordo com a sua finalidade arrecadatória ou regulatória, sem exigir com isso uma interpretação jurídica da norma que veicule a medida, o sistema tributário nacional caminhou no sentido da limitação das técnicas de intervenção do Estado sobre o domínio econômico por indução tributária.

Nesse sentido, a constituição concedeu ao Senado Federal competência para limitar os parâmetros das alíquotas em todos os impostos estaduais, o ITCMD, IPVA e ICMS, e previu leis complementares para fixar as alíquotas do ISS municipal. ${ }^{387}$ Da mesma forma, previu leis complementares para dispor sobre a forma e as condições para concessões de isenções, incentivos e benefícios fiscais de ICMS e ISS. ${ }^{388}$ Por fim, previu também as hipótese e formas de variação progressiva das alíquotas de IPTU. ${ }^{389}$

Partindo desse quadro é possível aprofundá-lo, pela promulgação de novas leis complementares dos impostos mais problemáticos (como um adendo à Lei Complementar 24/1975) ou de normas gerais de direito tributário, estabelecendo sanções aos governadores e prefeitos que lancem mão destes artifícios à revelia de sua

\footnotetext{
${ }^{387}$ Artigo 155, § 1 ${ }^{\circ}$, inciso IV; Artigo 155, $\S 2^{\circ}$, incisos IV e V; Artigo $155 \S 6^{\circ}$, incisos I e II; e Artigo 156, $\S$ $3^{\circ}$, inciso I. In: BRASIL. Constituição (1988). Constituição da República Federativa do Brasil: promulgada em 5 de outubro de 1988. Organização do texto: Juarez de Oliveira.

${ }^{388}$ Artigo 155, § $2^{\circ}$, incisos XII, alínea "g"; e Artigo 156, § $3^{\circ}$, inciso III. In: Idem.

${ }^{389}$ Artigo 156, $\S 1^{\circ}$, incisos I e II; e Artigo $182, \S 4^{\circ}$, inciso II. In:Idem.
} 
incompetência constitucional para fazer uso extrafiscal destes tributos, à semelhança da Lei de Responsabilidade Fiscal. Dessa forma, pode-se caminhar para a elaboração de uma espécie de "Lei de Responsabilidade Tributária Extrafiscal".

Posteriormente, uma tendência seria transitar para consolidação de um sistema tributário verdadeiramente nacional, de um federalismo cooperativo, em que a repartição das fontes tributárias não se confunde com a capacidade de intervenção extrafiscal, e que a mesma seja de fato concorrente, cabendo à União estabelecer regras gerais; aos estados suplementá-las ou estabelecê-las na ausência de lei federal, e aos municípios intervir sobre os temas de interesse local ou supletivamente à União e aos estados.

Inevitavelmente, no federalismo brasileiro a capacidade de estados e municípios fazerem política econômica é restrita. Em um sistema tributário nacional integrado, não há como a intervenção por extrafiscalidade alocativa dos estados e municípios se dar à custa da estabilidade macroeconômica do país. Contudo, há, sim, espaço para políticas extrafiscais de estados e municípios, mas esse é o espaço de sua autonomia legislativa residual, comum e supletiva estabelecida na constituição.

Nada impede, porém, que as expensas de tornar mais rígida a restrição à capacidade de estados e municípios intervenham na economia por extrafiscalidade alocativa de seus tributos, que se ampliem as transferências intergovernamentais a todos os tributos da União, sobretudo estendendo às contribuições sociais a obrigatoriedade de repartição. Essa medida fortaleceria a cooperação federativa e estimularia a União à incidir de forma mais contundente sobre a regressividade do sistema tributário, o que até hoje vem sendo postergado em razão das disfunções e descoordenações federativas.

A esse respeito é precisa a constatação de Erika Amorim Araújo de que passamos de um modelo sustentado pela tributação de mercadorias produzidas no exterior e consumidas internamente para um modelo sustentado na tributação de mercadorias produzidas internamente. ${ }^{390}$ A principal fonte de financiamento do Estado seguiu sendo a tributação indireta, ainda que realizada de forma mais coordenada e racional da perspectiva do mercado.

\footnotetext{
${ }^{390}$ ARAÚJO, Erika Amorim. A Tributação do Consumo pela Sistemática do Valor Adicionado em Contextos Federativos: Problemas e Possíveis Alternativas para Lidar com a Questão. Campinas: Unicamp - Instituto de Economia. Dissertação de Mestrado, 1999, p. 132.
} 
Entretanto, para enfrentar esses desafios do sistema tributário, que concernem à sua capacidade de viabilizar ações distributivas e alocativas eficientes, é preciso que solucionemos os impasses jurídicos em torno das competências para intervenção econômica pela tributação. Tarefa essa que, a nosso ver, ao menos do ponto de vista acadêmico, avança ao nos debruçarmos sobre uma compreensão própria e autônoma da regulação jurídica da extrafiscalidade da tributação brasileira. 


\section{BIBLIOGRAFIA}

ABREU, Marcelo de Paiva (org.). A Ordem do Progresso: Cem Anos de Política Econômica Republicana, 1889-1989. Rio de Janeiro: Campus, 1990.

AFONSO, José Roberto. A Questão Tributária e o Financiamento dos Diferentes Niveis de Governo. In: ÁLVAREZ AFFONSO, Rui Britto; e BARROS SILVA, Pedro Luiz. (orgs.). A Federação em Perspectiva: Ensaios Selecionados. São Paulo: Fundap, 1995.

AFONSO, José Roberto Rodrigues; e ARAÚJO, Erika Amorim, Pós-constituinte e Impostos Indiretos: Deformar ou Reformar? In: BIASOTO JÚNIOR, Geraldo e PINTO, Márcio Percival Alves (orgs.). Política Fiscal e Desenvolvimento no Brasil. Campinas: Editora Unicamp, 2006.

AGUILLAR, Fernando Herren. Direito Econômico: Do Direito Nacional ao Direito Supranacional. $2^{\text {a }}$ ed. São Paulo: Atlas, 2009. . Metodologia da Ciência do Direito. São Paulo: Atlas, 2009.

AMARAL MARTINS, Gustavo do. Mercado e Tributação: Os Tributos, sua relação com a Ordem Econômica e a Necessidade de Considerá-la na Interpretação e Aplicação do Direito Tributários. In: DOMINGUES, José Marcos (coord.). Direito Tributário e Políticas Públicas. Belo Horizonte: MP, 2008.

ANDRADE, José Maria Arruda de. Interpretação da Norma Tributária. 1. Ed. v. 1. São Paulo: MP Editora, 2006. 
. Interpretação e Aplicação da Lei Tributária: da Consideração Econômica da Norma Tributária à Análise Econômica do Direito. In: Hugo de Brito Machado. (Org.). Interpretação e Aplicação da Lei Tributária. São Paulo: Editora Dialética, 2010.

ARAÚJO, Erika Amorim. A Tributação do Consumo pela Sistemática do Valor Adicionado em Contextos Federativos: Problemas e Possíveis Alternativas para Lidar com a Questão. Campinas: Unicamp - Instituto de Economia. Dissertação de Mestrado, 1999.

ASSUNÇÃO, Matheus Carneiro. Incentivos Fiscais e Desenvolvimento Econômico: a função das normas tributárias indutoras em tempos de crise. Finanças Públicas - XV Prêmio Tesouro Nacional. 2010.

ATALIBA, Geraldo. Sistema Constitucional Tributário Brasileiro. São Paulo: Revista dos Tribunais, 1968. . Apontamentos de Ciência das Finanças: Direito Financeiro e Tributário. $2^{\mathrm{a}}$ Ed. São Paulo: Revista dos Tribunais, 1969. . Hipótese de Incidência Tributária. $6^{\mathrm{a}}$. Ed. $13^{\mathrm{a}}$ Tiragem. São Paulo: Malheiros, 1999.

BALEEIRO, Aliomar. Direito Tributário Brasileiro. Rio de Janeiro: Forense, 1970. Uma Introdução à Ciência das Finanças. 14ª . Ed. Rio de Janeiro: Forense, 1984. 
. Limitações Constitucionais ao Poder de Tributar. $7^{\text {a }}$ Ed. Rio de Janeiro: Editora Forense, 2006.

BECKER, Alfredo Augusto. Carnaval Tributário. São Paulo: Saraiva, 1989.

. Teoria Geral do Direito Tributário. 4ª . Ed. São Paulo: Noses, 2007.

BERCOVICI, Gilberto. Dilemas do Estado Federal Brasileiro. Porto Alegre: Livraria do Advogado, 2004.

- Constituição econômica e desenvolvimento - Uma leitura a partir da constituição de 1988. São Paulo: Malheiros, 2005.

. O Ainda Indispensável Direito Econômico. In: BENEVIDES, Maria Victoria de Mesquita; BERCOVICI, Gilberto; MELO, Claudineu de. Direitos Humanos, Democracia e República: Homenagem a Fabio Konder Comparato. São Paulo: Quartier Latin, 2009.

. O Direito Constitucional passa e o Direito Administrativo fica. In: TELES, Edson; e SAFATLE, Vladimir (orgs.). O que Resta da Ditadura. São Paulo: Boitempo, 2010.

. Direito Econômico do Petróleo e dos Recursos Minerais. São Paulo: Quartier Latin, 2011.

- Política Econômica e direito econômico. In: Revista Fórum Direito Financeiro e Econômico - RFDFE I Belo Horizonte, ano I, n ${ }^{\mathrm{o}}$ 1, mar/ago 2012, p. 199-219. 
BIASOTO JÚNIOR, Geraldo e PINTO, Márcio Percival Alves (orgs.). Política Fiscal e Desenvolvimento no Brasil. Campinas: Editora Unicamp, 2006.

. O Sistema Tributário Brasileiro: uma Trajetória de Fragmentação. In: BIASOTO JÚNIOR, Geraldo e PINTO, Márcio Percival Alves (orgs.). Política Fiscal e Desenvolvimento no Brasil. Campinas: Editora Unicamp, 2006.

BOBBIO, Norberto. Da Estrutura à Função: Novos Estudos de Teoria do Direito. Trad. Daniela Beccaccia Versiani. Barueri: Manole, 2007.

BRASIL. Constituição (1988). Constituição da República Federativa do Brasil: promulgada em 5 de outubro de 1988. Organização do texto: Juarez de Oliveira.

BRASIL. Lei $\mathrm{n}^{0}$ 5.172, de 25 de outubro de 1966. Dispõe sobre o Sistema Tributário Nacional e institui norma gerais de direito tributário aplicáveis à União, Estados e Municípios. In: Vade Mecum Tributário e Financeiro. Florianópolis: Conceito, 2010. Organização do texto: João Batista Lazzari et al.

BRASIL. Supremo Tribunal Federal. Súmula nº 656. In: Vade Mecum Tributário e Financeiro. Florianópolis: Conceito, 2010. Organização do texto: João Batista Lazzari et al.

BUCHANAN, James M. e MUSGRAVE, Richard A. Public Finance and Public Choice: Two Contrasting Visions of the State. Cambridge: MIT Press, 1999.

BUCCI, Maria Paula Dallari Bucci (coord.). Políticas Públicas: Reflexões sobre o Conceito Jurídico. São Paulo: Saraiva, 2006. 
BULHÕES, Octávio Gouvêa de. Aspectos da Reforma Tributária. In: Revista de Direito Administrativo. Vol. 113, Rio de Janeiro, 1973, p. 1-6.

CALIENDO, Paulo. Direito Tributário e Análise Econômica do Direito: Uma Visão Crítica. Rio de Janeiro: Elsevier, 2009.

CALLON, Michel. Introduction: The Embeddedness of Economic Markets in Economics. In: CALLON, Michel (ed). The Laws of the Markets. Oxford: Blackwell Publishers, 1998.

. An Essay on Framing and Overflowing: Economic Externalities Revisited by Sociology. In: CALLON, Michel (ed). The Laws of the Markets. Oxford: Blackwell Publishers, 1998.

Actor-network Theory - the Market Test. In: LAW, John; and HASSARD, John (ed). Actor Network Theory: and After. Oxford: Blackwell Publishers, 1999, p. $181 / 195$.

CAMPOS, Dejalma de. A dimensão Jurídica do Tributo In: MARTINS, Ives Gandra (org.). Tributo uma Reflexão Multidisciplinar sobre sua Natureza. Rio de Janeiro: Forense, 2007

CARDOSO JR, José Celso (org.). A Constituição Brasileira de 1988 Revisitada: Recuperação Histórica e Desafios Atuais das Políticas Públicas nas Áreas Econômica e Sociais. Vol. 1. Brasília: IPEA, 2009.

CARVALHO, Paulo de Barros. O Instituto da Isenção como Instrumento de Extrafiscalidade, Projeção: Revista Brasileira de Tributação e Economia, ano I, no 11, out/1976, p. 32/38. 
. Teoria da Norma Tributária, Max Limonad, $3^{\text {a }}$ Ed. São Paulo, 1998.

. Curso de Direito Tributário. 23 ${ }^{\mathrm{a}}$ Ed. São Paulo: Saraiva, 2011.

CARrAZA, Antonio Roque. Curso de Direito Constitucional Tributário. $28^{\mathrm{a}}$ ed. São Paulo: Malheiros, 2012.

COMPARATO, Fábio Konder. O indispensável Direito Econômico. In: Revista dos Tribunais. Ano 54. Vol. 353, São Paulo, 1965 pp. 15-26.

. Ensaio sobre o juízo de constitucionalidade de políticas públicas. In: BANDEIRA DE MELLO, Celso Antônio. Estudo em Homenagem a Geraldo Ataliba. v. 2. São Paulo: Malheiros, 1997.

CONTI, José Maurício. Princípios Tributários da Capacidade Contributiva e da Progressividade. São Paulo: Dialética, 1996.

- Sistema Constitucional Tributário Interpretado pelos Tribunais. São Paulo: Oliveira Mendes, 1997.

CORRÊA, Walter Barbosa. Contribuição ao Estudo da Extrafiscalidade. São Paulo: Faculdade de Direito da USP. Tese de Livre Docência, 1964.

DAIN, Sulamis. A Economia Política da Reforma Tributária de 2003. In: BIASOTO JÚNIOR, Geraldo e PINTO, Márcio Percival Alves (orgs.). Política Fiscal e Desenvolvimento no Brasil. Campinas: Editora Unicamp, 2006 
DALlARI BUCCI, Maria Paula. O Conceito de Política Pública em Direito. In: DALlARI BUCCI, Maria Paula (org.). Políticas Públicas: Reflexões sobre o Conceito Jurídico. São Paulo: Saraiva, 2006.

DEODATO, Alberto. As Funções Extra-Fiscais do Imposto. Belo Horizonte: Faculdade de Direito da Minas Gerais. Tese para o Concurso de Professor Catedrático de Ciência das Finanças, 1949.

. Manual de Ciência das Finanças. 13 ${ }^{\mathrm{a}}$ Ed. São Paulo: Saraiva, 1973.

DE PAULA, Tomás Bruginsky. Padrões de Financiamento do Setor Público Uma Análise do Sistema Fiscal e do Setor Produtivo Estatal no Brasil. Campinas: Unicamp - Instituto de Economia. Dissertação de Mestrado, 1989.

FERRAZ JR, Tércio Sampaio. Função Social da Dogmática Jurídica. São Paulo: Max Limonad, 1998.

FIGUEIREDO, Ademir Picanço de. Conflito Fiscal Federativo: Os incentivos dos Estados na Jurisprudência do STF. Belém: Universidade Federal do Pará. Dissertação de Mestrado, 2007.

FURTADO, Celso. O Longo Amanhecer: Reflexões sobre a Formação do Brasil. $2^{\mathrm{a}}$ Ed. Rio de Janeiro: Paz e Terra, 1999.

GIAMBIAGI, Fabio e ALÉM, Ana Cláudia. Finanças Públicas: Teoria e Prática no Brasil. $2^{\text {a }}$ Ed. Rio de Janeiro: Elsevier, 2000.

GIANNINI, A. D. Elementi di Diritto Finanziario, Milano, Dott. A. Giuffrè Editore, 1945. 
GRAU, Eros Roberto. A ordem econômica na constituição de 1988 (interpretação e crítica). $8^{\text {a }}$ Ed. São Paulo: Malheiros, 2003.

GRIZIOTTI, Benvenuto. Principios de Ciencia de las Finanzas. Trad. Dino Jarah, Ed. Roque Depalma, Buenos Aires, 1959.

GOUVÊA, Marcus de Freitas. A Extrafiscalidade no Direito Tributário. Belo Horizonte: Del Rey, 2006.

HAMILTON, Alexander; MADISON, James; e JAY, John. O Federalista. Trad: Hiltomar Martins Oliveira. Belo Horizonte: Líder, 2003

JUSTEN FILHO, Marçal. Sistema Constitucional Tributário: Uma Aproximação Ideológica. Curitiba. Revista da Faculdade de Direito da UFPR. Ano 30. N ${ }^{\mathrm{o}} 30$, 1998.

KELSEN, Hans. Teoria Pura do Direito. Trad. João Baptista Machado. $6^{\mathrm{a}}$ Ed. São Paulo: Martins Fontes, 1988.

KEYNES, John Maynard. A Teoria Geral do Emprego, do Juro e da Moeda. Trad. Mário R. da Cruz. São Paulo: Atlas, 1992.

KORNIS, George Edward Machado. Repensando o PAEG: Uma Revisão das Análises da Política Econômica Brasileira - 1964-1966. Campinas: Unicamp Instituto de Filosofia e Ciências Humanas. Dissertação de Mestrado, 1983.

LEAL, Victor Nunes. Coronelismo, Enxada e Voto: O Município e o Regime Representativo no Brasil. 7a. Ed. São Paulo: Companhia das Letras, 2012. 
LOBO, Rogério Leite. Os Atos de Tributação Interventivos no Domínio Econômico: Proposta de Classificação e Considerações sobre o seu Regime Jurídico. In: Revista de Direito Administrativo, Vol. 232, Rio de Janeiro, 2003, pp. 29-52.

LOPREATO, Francisco Luiz Caseiro. O Colapso das Finanças Estaduais e a Crise da Federação. São Paulo: UNESP, 2002.

MARTINS, Ives Gandra (org.). Tributo uma Reflexão Multidisciplinar sobre sua Natureza. Rio de Janeiro: Forense, 2007.

MONTEIRO DE BARROS, Theotônio M. B. Filho. As taxas e seus problemas teóricos. São Paulo: Revista dos Tribunais, 1941.

MORAES, Bernardo Ribeiro de. A Constituição de 1967 e a Infra-Estrutura Tributária. In: Revista de Direito Público, Vol. 2, 1969.

MUSGRAVE, Richard. A. Teoria das Finanças Públicas: Um Estudo de Economia Governamental. Trad: Auriphebo Berrance Simões. Vol 1. São Paulo: Atlas, 1973.

NAVARRO COELHO, Sacha Calmon. Teoria Geral do Tributo e da Exoneração Tributária. 2a . Ed. Belo Horizonte: Del Rey, 1999.

NOGUEIRA, Ruy Barbosa. Curso de Direito Tributário. São Paulo: Saraiva, 1986.

NUNES, Antonio José Avelãs. Uma Introdução À Economia Política. São Paulo: Quartier Latin, 2007. 
OLIVEIRA, Fabrício Augusto de. A Reforma Tributária de 1966 e a Acumulação de Capital no Brasil. $2^{\mathrm{a}}$ ed. Belo Horizonte: Oficina de Livros, 1991.

. Crise, Reforma e Desordem do Sistema Tributário Nacional. Campinas: Editora da Unicamp, 1995.

. A Lógica das Reformas: A Evolução do Sistema Tributário (1966-2002). In: BIASOTO JÚNIOR, Geraldo e PINTO, Márcio Percival Alves (orgs.). Política Fiscal e Desenvolvimento no Brasil. Campinas: Editora Unicamp, 2006.

OLIVEIRA, Francisco de, A Crise da Federação: da Oligarquia à Globalização. In: ÁlVAREZ AFFONSO, Rui Britto; e BARROS SILVA, Pedro Luiz. (orgs.). A Federação em Perspectiva: Ensaios Selecionados. São Paulo: Fundap, 1995.

PAULSEN, Leandro. Direito Tributário: Constituição e Código Tributário à luz da Doutrina e da Jurisprudência. Porto Alegre: Esmafe, 2009.

QUADROS, Waldenir Luiz de. O ICMS e a Tributação do Valor Adicionado: Uma análise da Sistemática da Tributação do Consumo no Brasil. Campinas: Unicamp Instituto de Economia. Dissertação de Mestrado, 1994.

REZENDE, André Lara. Estabilização e Reforma: 1964-1967. In: ABREU, Marcelo de Paiva (org.). A Ordem do Progresso: Cem Anos de Política Econômica Republicana, 1889-1989. Rio de Janeiro: Campus, 1990.

RESENDE, Fernando. O Financiamento das Políticas Públicas: Problemas Atuais. In: ÁlVAREZ AFFONSO, Rui Britto; e BARROS SILVA, Pedro Luiz. (orgs.). A Federação em Perspectiva: Ensaios Selecionados. São Paulo: Fundap, 1995. 
. ICMS: Gênese, Mutações, Atualidade e Caminhos para Recuperação. Brasília: IDP e FGV Projetos. vol 2.

REZENDE, Fernando; OLIVEIRA, Fabrício Augusto de e ARAÚJO, Erika Amorim. O Dilema Fiscal: Remendar ou Reformar? Rio de Janeiro: FGV, 2007.

RIBEIRO, Bernardo. Infra-Estrutura Tributária. Doutrina RDP-2.

SCHUMPETER, Joseph Alois. The Economics and Sociology of Capitalism. Ed: Richard Swedberg. New Jersey: Princeton University Press, 1991.

SHOUERI, Luís Eduardo. Normas Tributárias Indutoras e Intervenção Econômica. Rio de Janeiro: Forense, 2005.

SOUZA, Rubens Gomes de. A Reforma Tributária no Brasil. In: Revista de Direito Administrativo, vol. 87, Rio de Janeiro, 1967, pp. 1-16.

_. Compêndio de Legislação Tributária: Parte Geral. $3^{\text {a }}$ Ed. São Paulo, 1975, IBET.

SOUZA, Washington Peluso Albino de. Direito Econômico. São Paulo: Saraiva, 1980.

TORRES, Heleno Taveira. Incentivos Fiscais na Constituição e o "crédito prêmio de IPI”. Revista Fórum de Direito Tributário - RFTD, ano 3, n. 14, 2005. 
TORRES, Ricardo Lobo. A Chamada "Interpretação Econômica do Direito Tributário", A Lei Complementar 104 e os Limites Atuais do Planejamento Tributário. In: Revista Ciências Sociais, Vol. 7, nº 1, Rio de Janeiro, 2001, pp. 2937.

. As Influências Italianas no Direito Tributário Brasileiro. In: Revista de Direito Tributário, v. 84, São Paulo, Malheiros, 2002, p. 80.

. Interpretação e Integração da Lei Tributária. In: Hugo de Brito Machado. (Org.). Interpretação e Aplicação da Lei Tributária. São Paulo: Editora Dialética, 2010, p. 333-355.

. Curso de Direito Financeiro e Tributário. $18^{\mathrm{a}}$ Ed. São Paulo: Renovar, 2011.

VARSANO, Ricardo. A Evolução do Sistema Tributário ao Longo do Século: Anotações e Reflexões para Futuras Reformas. Rio de Janeiro: Texto para Discussão n ${ }^{\circ} 405$ IPEA, 1996.

VENÂNCIO FILHO, Alberto. A intervenção do Estado no domínio econômico: o Direito público econômico no Brasil. Rio de Janeiro: Renovar, 1998.

VIDIGAL, Geraldo de Camargo. Teoria Geral do Direito Econômico. São Paulo: Revista dos Tribunais, 1977.

WATANABE, Marta. Economistas divergem sobre estratégia de fazer uma reforma tributária “fatiada”. Valor Econômico, São Paulo, 30 de outubro de 2012. $1 \mathrm{cad}$. página A2. 
WEBER, Max. Economia e Sociedade. Trad. Regis Barbosa e Karen Barbosa. Vol. 2. Brasília: Editora UNB, 1999.

. O Direito na Economia e na Sociedade. Trad. Marsely De Marco Martins Dantas. $1^{\text {a }}$ Ed. São Paulo: Ícone, 2011. 